\title{
Index for Volume 102
}

AUTHOR AND SUBJECT INDEX. Page numbers of errata are in italic.

Abad, Z., S4.15

Abawi, G., S1.1

Abbas, H., S2.9, S4.133

Abbas, H. D., S4.1

$\mathrm{ABC}$ transporter gene, from Sclerotinia

homoeocarpa, propiconazole resistance and, S4.105

Abd El Kreem, R. Y., S4.77

Abd-Elmagid, A. W., S2.1

Abdel-Razik, A. A., S2.1

Abdelsamad, N., S4.1

Abdelsamad, N. A., S4.142

Abdelshahid, L., S4.82

Abeysekara, N., S4.1, S4.77

Abeysekara, N. S., 94

Abies balsamea (balsam fir), Phytophthora ramorum on, $\mathrm{S} 1.8$

Abo, K., 733

Abou Ghanem-Sabanadzovic, N., S4.2

Abouelnasr, H., S4.69

Abou-Zeid, N. M., S4.120

Abrameit, A., S4.57

Abramova, S., S4.57

Acephala applanata, ectomycorrhiza on conifer seedlings colonized by dark septate endophytes and, S4.98

Acevedo, M., S4.42, S4.145, S5.4

Acharya, B., S5.9

Achata, J., S4.50

Achenbach, U. C. M., 185

Achor, D., S4.103

Acidbenzolar-S-methyl (ASM), for control of

huanglongbing in young citrus, S4.47

Acidovorax spp.

A. avenae subsp. avenae, on creeping bentgrass, S4.45

A. citrulli, in watermelon seeds, $461, \mathrm{~S} 2.10$

ACR toxins, Alternaria alternata on rough lemon and, 741

ACRTS1 gene, host-selective ACR toxin in Alternaria alternata on rough lemon and, 741

Actin cytoskeleton, Barley stripe mosaic virus and,

TGB proteins and, S4.69

Actinidia spp. (kiwifruit), Pseudomonas syringae pv. actinidiae on

anatomical changes in wood and primary infection sites, 827

phylogenetic relationships among global populations, 1034

population structure and possible origin of, S6.6

Acuña, R., S4.118

Acyl carrier protein, Erwinia amylovora virulence and, S4.67

Acyl homoserine lactone (AHL), production of rubrifacine by Brenneria rubrifaciens and, 195

Adam, G., S4.146

Adams, B. E., S4.2

Adaskaveg, J., S4.2, S6.9, S6.10

Adaskaveg, J. E., 528, S4.129

Addy, H. S., 244, 469

Adhikari, B., S1.5, S4.113

Adhikari, T. B., 390

Adkins, S., S4.65, S4.98, S4.122, S4.133

Adkison, H. M., S4.2

Aedes triseriatus mosquitoes, LaCrosse virus and

mating behavior of, S4.149

Aegerter, B., S6.7

Aegilops tauschii, as a source of resistance of wheat

to Puccinia triticina $\mathrm{f}$. sp. tritici on, S4.61

Afkhami, M., S4.117, S4.160

Afla-Guard

Aspergillus flavus diversity in fields treated with, S2.9

for management of aflatoxin in corn, S4.133
Aflatoxin

atoxigenic Aspergillus flavus for management of, $\mathrm{S} 4.58, \mathrm{~S} 6.2$

in corn

Afla-Guard for management of, S4.133

Aspergillus flavus AF36 for control of in Mexico, S4.89

transcriptomic and protein profiling of seed

with varying accumulation of, S4.73

WRKY transcription factors and resistance, S4.40

in peanut, weather variables for predicting, S4.14

Afton, D., S4.147

Agindotan, B. O., S4.157

Agrobacterium spp.

A. tumefaciens

biovar 1, on walnut in California, S4.76

diversity of in Yuba County, California, S6.9

on walnut, identification of sources of resistance in germplasm, $\mathrm{S} 4.78$

A. vitis, on grape, magnetic capture hybridization and real-time PCR of, S4.59

Agrostis stolonifera (creeping bentgrass)

Acidovoraxavenae subsp. avenae on, S4.45

Colletotrichum cereale on, temperature and appressorium formation, S4.132

Sclerotinia homoeocarpa on irrigation management of, $\mathrm{S} 4.33$ weather-based fungicide application advisor for, S4.111

strobilurin fungicide applications and, plant health benefit of, S4.11

Agudelo, P., 804

Aguilar, K. I., S4.27

Aguilar-Granados, A., S4.110

Ahamed, A., S4.75

AHL. See Acyl homoserine lactone

Ahonsi, M. O., S4.2

Ailanthus altissima, Verticillium nonalfalfae on, risk analysis for, S4.62

Aime, M. C., S4.103, S4.106

Aiseam, C. C., S4.106

Akgul, S. D., S4.123

Akimitsu, K., 741

Akinbade, S. A., S4.2

Akinsanmi, O. A., S4.51

Akridge, J., S4.14

Al-Abedy, A., S4.120

Alberto, R. T., S6.7

Albrectsen, B., S4.40

Alcaligenes faecalis, on citrus, in Iran, S4.3

Alderman, S. C., S4.123

Aldolase, from soybean cyst nematode, in trans-

formed soybean roots, posttranscriptional gene silencing of, $\mathrm{S} 4.77$

Alexander, B. J. R., 1034

Alfalfa. See Medicago sativa

Algae-based biofertilizers, effects on plant growth promotion, S5.2

Ali, A., 166

Ali, G. S., S4.91

Ali, S., S4.3, S4.143

Alimi, M., S4.3, S4.117

Alkyl dimethyl ammonium chloride, for Pseudo-

monas syringae pv. syringae on bean, S4.122

Allee, E. F., S4.139

Allen, C., S4.56, S4.121, S4.151

Allen, J., S1.3

Allen, T., S4.133

Allen, T. W., S2.5, S4.3, S4.45

Allison, J., S4.87

Allium spp., A. cepa (onion), ipmPIPE project, S4.107
Allium spp

A. cepa (onion)

DNA macroarray for detection of bulb rot pathogens of, S4.125

factors associated with bacterial diseases of, S1.7

Iris yellow spot virus in: overwintering onion thrips as source of, S4.117; seasonal dynamics and onion thrips, S4.8

Pantoea agglomerans and Pectobacterium caratovora on, in Pennsylvania, S4.92

postharvest diseases of in Utah, S6.11

Pseudomonas viridiflava on, S2.5

Sclerotium cepivorum on, combining sclerotia germination stimulants and fungicides for control of, S4.39

twister disease of, gibberellic acid and, S6.7

A. sativum (garlic), Sclerotium cepivorum on,

combining sclerotia germination stimulants and

fungicides for control of, S4.39

Almeida, R., S4.164, S5.3

Almeida, R. P., S6.13

Almeyda, C. V., S4.3

Almond. See Prunus dulcis

Al-Mughrabi, K. I., S4.62

Alpinia purpurata (flowering ginger), Banana bract mosaic virus in, in Hawaii, S4.131

Al-Saleh, M., S4.56

Al-Shahwan, I., S4.56

Alternanthera mosaic virus (AltMV)

interaction with Nicotiana benthamiana PSB01, S4.58

TGB1 interaction with chloroplast beta ATPase, viral replication and, $\mathrm{S} 4.85$

Alternaria spp.

A. alternata

on apple: dynamics of growth regulators during infection by, S4.21; effect of host physiology on, 769

fluopyram resistance development in, S4.84 on rough lemon, 741

on tangerine, geographic and cultivar distribution of QoI-resistant isolates, S4.127

on apple, in Australia, S4.51

A. arborescens, on tomato, horizontal gene transfer and, S4.161, S5.5

A. brassicae, on cauliflower, transcriptome profiling of CYP83B1 during, S4.108

A. brassicicola on cauliflower, transcriptome profiling of CYP83B1 during, S4.108

four transcription factors regulating pathogenesis in, $\mathrm{S} 4.24$

collected from apple in Italy, comparison with $A$. mali and other AM-toxin producing strains, 1130

comparative genomics for species resolution in, S4.162

A. grandis, on potato, Phytophthora infestans and, comparative epidemiology in Brazil, S4.32

A. japonica, on basil, effects of increased $\mathrm{CO}_{2}$ and temperature on, $\mathrm{S} 4.94$

A. panax, on araliaceous plants, $\mathrm{S} 4.142$

on potato, azoxystrobin resistance in, S5.3

A. solani

on potato: detection and characterization of boscalid resistance in, S4.36; evaluating fungicide programs for in Wisconsin, S4.44 resistance to in hybrids between a Solanum tuberosum haploid and S. raphanifolium, 214

two new species-groups within, S4.138

Alternate hosts, for Phytophthora infestans on potato, 429 
AltMV. See Alternanthera mosaic virus

Alvarado, O. G., S6.2

Alvarez, A. M., 105, S4.121, S4.141

AM toxin, Alternaria spp. collected from apple in

Italy and, 1130

Amaradasa, B. S., S4.4

Amari, K., 1108

Amarillaria mellea, identification of tree-crop root-

stocks with resistance to, $\mathrm{S} 4.10$

Ambrose, K. V., S1.1

Ambrosia asymptomatic virus 1 , as new Man-

darivirus, S4.33

Ambrosia beetles. See Euwallacea fornicatus; Xyle-

borinus spp.

Ameen, G, S5.1

Ameen, G., S4.4

Amemiya, Y., S4.125

American beech. See Fagus grandifolia

Ames, K. A., S4.2, S4.133, S5.4

$\beta$-Aminobutanoic acid (BABA). See BABA

2-Aminoimidazole (2-AI), for control of Monilinia

fructicola by, S4.70

Amiri, A., S4.4

Ammar, E., S4.5

Amorim, L., S4.25, S4.41, S4.46

Ampelomyces spp.

attack of Erysiphe necator by in field, 707

A. quisqualis, for Erysiphe necator on grape, S4.68

Ampelovirus

associated with sugarberry, S2.11

novel, in blackberry, S4.119

Amplex Red, for estimation of reactive oxygen

species, S5.2

Amundsen, K., S4.4

Amylostereum areolatum, in native Sirex populations,

S4.87

Amylovoran, production of by Erwinia amylovora,

orphan gene amyR as negative regulator of, S4.131

Amyotte, S., S4.17, S4.120

AmyR gene, amylovoran production by Erwinia

amylovora and, S4.131

Anaerobic soil disinfestation (ASD), transformation

of soil microbial community structure in response

to, $\mathrm{S} 4.77$

Ananthakrishnan, G., S6.1

Anastrepha spp. (fruit flies)

A. ludens, bacterial used to increase larval survivorship of, S6.1

A. obliqua, in Jamaica, molecular analysis of using mitochondrial markers, S6.3

Ancona, V., S4.5, S4.70

Andersen, K. F., S4.5

Andersen, P. C., S4.113

Anderson, D. D., S2.1, S2.9

Anderson, G., S5.1

Anderson, J., S4.39, S4.138

Anderson, J. C., S4.6

Andersson, B., 323, 429

Andreason, S., S4.5

Andromeda, Japanese. See Pieris japonica

Angel, C. A., S4.5, S4.6

Anisogramma anomala, on hazelnut draft genome of, S1.2

microsatellite markers for, $\mathrm{S} 1.4$

Annis, S. L., S4.119

Annual bluegrass. See Poa annua

Ansley, J., S4.137

Antagonistic bacteria, isolated from plant-disease suppressive niches, genetic analysis of, S4.139

Anthracnose. See Colletotrichum gloeosporioides

Anthriscus cerefolium (chervil), Plectosporium

tabacinum on, S4.125

Antibiotics, for Erwinia amylovora on apple, in

Illinois, streptomycin-resistant, S4.60

Antilla, L., S4.58

Antimicrobial activities, of bacteria isolated from

plant-disease suppressive niches, genetic analysis of, S4.139
Antioxidants

Pseudomonas syringae on Arabidopsis thaliana and, 662

up-regulation of in tobacco by hydrogen peroxide, suppression of necrotic disease symptoms and, 848

Aparicio, F., 1108

Aphanomyces euteiches, on pea, normalized changes

in gene expression in response to infection, S4.104 Aphelenchoides spp.

colonization of Sclerotinia sclerotiorum by, S6.9

A. fragariae differential expression of a $\beta$-1,4-endoglucanase induced by diet change in, 804 on ornamentals, management of, S4.66

SSU rDNA phylogenetic analysis of and quantitative detection of in complex DNA backgrounds, 1153

Aphids

GFP-tagged Cucumber mosaic virus expression in Nicotiana benthamii following transmission by, $\mathrm{S} 4.65$

Potato virus $Y$ in potato, $\mathrm{S} 4.148$

Raspberry latent virus transmission and, 547

Sweetpotato feathery mottle virus in sweetpotato and, S2.11

Aphis gossypii, sweet potato potyviruses and, S4.138 Apium graveolens (celery), Cercospora apii on, fun-

gicides for management of, S4.97

Appel, D. N., S4.78

Apple. See Malus domestica

Apple stem grooving virus (ASGV), genetic diversity

in North America, S4.2

Apple stem pitting virus (ASPV), genetic diversity in

North America, S4.2

Apps, for diagnosis and management of ornamental

plant health problems, S4.10

Apricot. See Prunus armeniaca

Aquilaria agallocha (Chinese eaglewood),

Meloidogyne enterolobii on, in China, S4.37

Arabidopsis thaliana

clubroot in, salicylic acid suppression of, S4.72

Hyaloperonospora arabidopsidis on, sublethal

UV irradiation and host resistance, S4.81

Pseudomonas syringae on, compartment-specific antioxidative defense in, 662

root-knot nematodes on, host gene silencing pathways and, S4.130

Arachidonic acid (AA), in Arabidopsis and tomato,

S4.100

Arachis hypogaea (peanut)

aflatoxin in, weather variables for predicting, S4.14

Cercospora arachidicola on

new runner-type cultivars, S2.8

penthiopyrad and pyraclostrobin for, S2.2

Cercosporidium personatum on

evaluation of ICRISAT varieties for resistance to, S2.4 evaluation of recombinant inbred line (RIL)

derived lines for resistance, $\mathrm{S} 2.4$ new runner-type cultivars, S2.8

evaluation of ICRISAT varieties for resistance to foliar diseases, S2.4

identification of expressed resistance gene analog (RGA) from peanut, marker development and, S4.71

impact of cropping sequence on diseases, nematodes, and yield of in southwest Alabama, S4.49

Puccinia arachidis on characterization of resistance, S4.151 evaluation of ICRISAT varieties for resistance to, S2.4 resistance in new breeding lines, $\mathrm{S} 2.8$

Pythium spp. on, effect of initial fungicide application timing and cultivar on, S2.10

relative efficacy of nine fungicides applied to, S2.1 resistance gene analogs from, S2.7

Rhizoctonia solani on, effect of initial fungicide application timing and cultivar on, S2.10

Sclerotinia spp. on

S. minor, fluopyram and cultivar selection for management of, S2.11

S. sclerotiorum: factors affecting mycelium pigmentation and pathogenicity of, S4.73; oxalic acid production, mycelium pigmentation and, S6.10

Tomato spotted wilt virus in

identification of putative resistance genes, S2.3, S4.37

improvements in field resistance, $\mathrm{S} 2.2$

resistant genotypes and interactions with thrips, S4.113

Aradyha, M., S4.78

Area under the disease progress curve (AUDPC),

413, S4.110

Area under the disease progress stairs (AUDPS), 381, S4.110

Arenz, B. E., S4.6

Arevalo, J., S4.118

Arias, R., S4.60

Arif, M., S4.5, S4.6, S4.20, S4.30, S4.89

Arinaitwe, W., S5.10

Ariss, J. J., S4.119

Aritua, V., S4.64

Armillaria spp.

A. mellea, on cherry and peach, iodomethane for control of, S6.10

phylogenetic relationships among northern hemisphere species, tef-1a locus and, S4.63

A. solidipes, transcriptome characterization of, candidate pathogenicity-related genes, S4.102

Arnold, K. L., S4.6, S4.7

Arnold, T. T., S4.88

Arriaga, F. J., S2.5

Arthur, K., S4.31

Asalf, B., S4.7

Ascencio, I., S4.13

Asclepias asymptomatic virus (AsAV), molecular characterization, ecology, and epidemiology of in Oklahoma, 166

Asclepias viridis (green milkweed), molecular characterization, ecology, and epidemiology of a novel tymovirus in, 166

Ascochyta rabiei, on chickpea, solanopyrone production and, S4.64

Asexual reproduction, taxonomic challenges of king-

dom Fungi species delineation and, S4.162

ASGV. See Apple stem grooving virus (ASGV)

Ashok Reddy, G., 222

Asian ambrosia beetle. See Euwallacea fornicatus

Asian citrus psyllid. See Diaphorina citri

Asian prunus viruses (APV), multiplex TaqMan real-

time RT-PCR assay for detection of, S4.71

Asija, P., S4.52

Askora, A., 244, 469

Aslaf, B., S4.7

ASM. See Acidbenzolar-S-methyl (ASM)

Asolkar, R. N., S4.119

Asophyllum nodosum extracts, for control of Xanthomonas axonopodis pv. vesicatoria on tomato, S3.2

Aspen. See Populus tremuloides

Aspergillus spp.

A. flavus

AF36, as endemic biocontrol agent for control of aflatoxin contamination in maize, $\mathrm{S} 4.89$ atoxigenic: long-term and area-wide influences of application of, S4.58; sporulation and field movement of, S6.2

on coconut, detection using ammonia treatment, S4.1

on corn: diversity in fields treated with Aflaguard, S2.9; mating type and biological control of, S4.28; WRKY transcription factors and aflatoxin resistance, $\mathrm{S} 4.40$ on maize: tissue-specific components of 
resistance to, 787; transcriptomic and protein profiling of seed with varying aflatoxin accumulation, S4.73; WRKY transcription factors and resistance, $\mathrm{S} 2.4$ section Nigri species, effect of drying methods on incidence of mycotoxins and mycotoxigenic strains, S4.89

ASPV. See Apple stem pitting virus

Atallah, Z., S4.109

Atallah, Z. K., 1071, S4.48

Atmospheric conditions, variability in Fusarium head

blight epidemics and, 55

$\beta$-ATPase, Alternanthera mosaic virus replication and, S4.85

ATR1 gene, role of in cercosporin resistance,

S4.53

Attanayake, R. N., S4.7

Attenuated viruses, Pepino mosaic virus, cross-

protection and, S5.3

Atwood, R. A., S6.2

Augusto, J., S2.1

Austin, C. N., 857

Auxin, Pantoea agglomerans pv. gypsophilae on

gysophila and, gall formation, S4.20

Avci, U., 461

Ave, M., 140

Ave1 gene, of Verticillium spp., allelelic variation in, S4.77

Avena sativa (oat), Puccinia graminis on, genetic

variation in, 1006

Averett, D., S4.89

Avila-Alistac, N., S4.15

Avirulence genes

of Magnaporthe oryzae, natural variation and evolution of, S4.59

Xanthomonas citri subsp. citri and Xanthomonas fuscans pv. aurantifolii, comparison between avrGf1 and $a v r G f 2$ which elicit hypersensitive reactions in, $\mathrm{S} 4.45$

Avis, T. J., S1.8

Avocado. See Persea americana

AvrPiz-t, rice innate immunity and, S4.165

Aynardi, B. A., S4.7

Azole fungicides, for Pyrenopeziza brassicae on

oilseed rape, reduced sensitivity, S4.19

Azoxystrobin

for Alternaria spp. on potato, resistance to, S5.3

for Bipolaris spp., alternative mechanisms of resistance in, S4.120

for Rhizoctonia solani on sugar beet, S5.7 seed and in-furrow, for Rhizoctonia solani on sugar beet, $\mathrm{S} 4.16$

BABA ( $\beta$-aminobutanoic acid), for control of

Phytophthora capsici on tomato, $\mathrm{S} 4.80$

Babadoost, M., S4.8, S4.60

Babiker, E. M., S4.8

Bacillus spp.

B. amyloliquefaciens

for control of Fusarium graminearum on wheat, S4.26

strain D747, new generation of bacterial biofungicides based on, S4.53

B. subtilis

for control of Ralstonia solanacearum on

tomato, biofilm formation and, S4.21

for Rhizoctonia solani on rice, S4.144

strain CU12, antifungal compounds from,

S1.8

strain IN937B, for control of Phytophthora capsici on squash, S4.81

strains AS 43.3 and $\mathrm{OH} 131.1$, genomic comparison of, S4.32

Backman, P. A., S1.7, S4.94, S4.118

Backus, E. A., S4.8

Bacsó, R., 848

Bactericera cockerelli (potato/tomato psyllid)

Candidatus Liberibacter and, comparative

genomic analysis of interaction, S4.164
Candidatus Liberibacter solanacearum on potato and, S4.137

effects of pathogen titer, vector numbers, and feeding sites, 1079

cellular interactions and transcript profiling of

Candidatus liberibacter asiaticus and solanacearum during psyllid infection and vectormediated transmission, S4.39

effects of Candidatus Liberibacter solanacearum on, 41

Baenziger, P. S., S4.134

Baer, D., S4.52

Baetsen, A. M., S4.8

Bag, S., S4.8

Bagadia, P. G., S4.8

Bagewadi, B., S4.49, S4.155

Bagi, F. F., S4.115

Bahder, B. W., S4.9

Bai, G., S4.86

Bai, L., 692

Bailey, B. A., S3.4

Baird, S., S2.7, S4.139

Bajwa, S. G., S2.3

Bakker, J., 140, 1153

Bakker, P. A. H. M., 403

Balachandran, S. M., 222

Balci, Y., S3.2, S3.3, S4.9, S4.11, S4.53, S4.78

Baldwin, B. S., S2.5, S4.45

Balestra, G. M., 827

Balint-Kurti, P., S4.21

Balint-Kurti, P. J., 1016

Balk, C. S., S5.5

Balkcom, K. S., S2.5

Balmer, D., S4.92

Balsam fir. See Abies balsamea

Banana. See Musa spp.

Banana bract mosaic virus (BBrMV), in flowering

ginger, in Hawaii, S4.131

Banana bunchy top virus (BBTV)

in banana and plantain, in Central Africa, S4.87

Buchnera GroEL from Pentalonia nigronervosa and, S4.132

Pentalonia nigronervosa and, RT-PCR and immunofluorescence assays for, S4.16

Banks, C., S4.92

Banks, C. J., S4.62

Banks, N. C., 620

Barak, J., S4.50, S4.112

Barak, J. D., S4.66, S4.94

Barash, I., 23, S4.20

Barasubiye, T., S4.92

Barba, P., 83, S4.18

Barbeau, A., S5.1

Barberry. See Berberis vulgaris

Barley. See Hordeum vulgare

Barley stripe mosaic virus (BSMV), host actin

cytoskeleton and TGB3 cell wall localization, S4.69

Barman, A., S4.33

Barney, W. P., S1.3

Baron, J., S1.6

Barphagha, I., S2.2

Barphagha, I. K., S2.8, S4.22

Barr, N., S6.3

Barr, S., S4.156

Bart, R., S4.148

Bartelt, K. D., 519

Bartholomay, L. C., S4.150

Bartz, J., S4.9

Bashir, N. S., S4.33

Basil. See Ocimum spp.

Bastidas, J., S4.80

Basu, D., S1.2

Batista da Silva, M., S4.9

Batuman, O., S4.9, S4.19

Baudoin, A., S3.1

Baughman, T. A., S2.11

Baum, T., S4.111

Baum, T. J., S4.107, S4.165
Baumgartner, K., S4.10

Bausher, M. G., S4.153

Baysal-Gurel, F., S4.10, S5.1

BBrMV. See Banana bract mosaic virus

BBTV. See Banana bunchy top virus

BCMV. See Bean common mosaic virus

$\mathrm{BCRV}$. See Blackberry chlorotic ringspot virus

BCTV. See Beet curly top virus

Beacham, J., S4.50

Bean. See Phaseolus vulgaris; Vigna spp.

Bean common mosaic virus (BCMV)

characterization of two field isolates of, $\mathrm{S} 4.93$

genome sequences of two isolates, S6.9

Bean golden mosaic virus (BGMV), epidemiology in transgenic lines, S4.37

Bean pod mottle virus (BPMV)

$5^{\prime}$ untranslated region and the 58 kilodalton protein and RNA2 replication, S5.6

detection with RT-PCR, RT-qPCR, and isothermal amplification, S4.20

Beanland, L., S3.2

Beaton, B. W., S4.62, S4.92

Beaty, B. J., S4.149

Beaudry, R. M., S5.5

Beauveria bassiana, for control of Sclerotinia sclerotiorum, S4.12

Beck, D., S4.166

Beckerman, J., S4.10, S4.64

Beckerman, J. L., S5.6

Becktell, M. C., S4.10

Beekman, V., 609

Beet. See Beta vulgaris

Beet curly top virus (BCTV)

characterization of genome plasticity of, S4.50

in sugar beet, host range studies of, S4.93

Begomoviruses

isolated from weed and cultivated plants in Yucatan Peninsula of Mexico, S4.83

in legumes, molecular identification in southeast Asia, S4.122

in stuffing cucumber, in Brazil, S4.71

transcriptome analysis of whitefly transmission of, S4.164

Behn, J. L., S5.2

Behringer, G., S4.11

Beirn, L. A., S1.

Bekal, S., S4.11

Bekoscke, K., S4.110

Bekoscke, K. A., S4.28

Belanger, F. C., S1.1

Beleza Yamagishi, M. E., S4.11

Bellizzi, M., S4.165

Below, F. E., S4.152

Bemisia tabaci (whitefly)

mtCOI primers for the rapid identification of, $\mathrm{S} 4.5$

transcriptome analysis of transmission of Begomoviruses and, S4.164

Benelli, J. J., S4.11

Benlioglu, S., S4.109

Benson, M., S4.14, S4.72, S4.73

Bent, A. F., S4.26

Bentgrass, creeping. See Agrostis stolonifera

Benzoic acid, for control of Magnaporthe oryzae on rice, $\mathrm{S} 4.126$

Beom, J., S4.58

Berberis vulgaris (barberry)

not alternate host for Puccinia striiformis f. sp. tritici in Pacific Northwest, S4.132

Puccinia graminis on, genetic variation in, 1006

Bereczky, Z., 707

Beresford, R. M., 147

Berg, A. S., S4.11

Bergamin Filho, A., S4.80, S4.82

Berger, P. H., S4.163

Bergstrom, G. C., S4.26

Berlin, A., 1006

Bermudagrass. See Cynodon dactylon

Bernal, A., S4.80, S4.117 
Berner, D. K., 761, S3.1, S4.13

Berthiller, F., S4.146

Bertolini, E., 114

Beseli, A., S4.11

Beta vulgaris (sugar beet)

Beet curly top virus in, host range studies of, S4.93

Cercospora beticola on

CbCyp 51 gene from, $\mathrm{S} 4.12$

characterization of $C b C y p 51$ from, 298

fungicide resistance in, S5.2

host sensing, stomatal tropism, initiation of

stomatal penetration and, S2.6

Macrophomina phaseolina on, S4.115

Phoma spp. on, variability in, S4.50

Pythium ultimum on, changes in bacterial

communities after organic amendments to two soils and, 413

Rhizoctonia solani on

azoxystrobin for control of, S5.7

fungicides for management of, S4.63

penthiopyrad for control of, S5.6

postharvest respiration rate and sucrose

concentration, S4.136

seed and in-furrow fungicides with and without postemergence azoxystrobin for control of, S4.16

Rhizoctonia-bacterial root rot complex in, influence of tillage systems on, S4.115

variability in postharvest rot response of sugar

beet, S5.5

Betaproteobacteria, molecular profiling of 16S RNA

sequence data, S4.112

Bettiga, L. J., S4.91

Betula platyphylla var. japonica (Japanese birch),

Inonotus obliquus on, peroxidase localization in infected plant, S4.141

Beuve, M., 717

BGMV. See Bean golden mosaic virus

Bhat, R. G., S4.16, S4.106

Bhatnagar, D., S4.84

Bhattacharrya, M., S4.1

Bienapfl, J. C., S4.11

Biernacka-Larocque, A., S4.22

Bignell, D. R., S4.158

Bilodeau, G. J., 331, S4.12

Bimolecular fluorescence (BiFC), for study of Iris

yellow spot virus proteins, $\mathrm{S} 4.121$

Bin-Umer, A., S1.2

Bioenergy crops

disease agents and, S4.156

grasses, increased susceptibility in, S4.157

impact of disease on biofuel production and, S4.156

sorghum, response of grain and stalk fungal pathogens, S4.157

viruses of, S4.157

Biofertilizers, effects on plant growth promotion,

S5.2

Biofilms

Bacillus subtilis, control of Ralstonia solanacearum on tomato and, S4.21

formation of by Xylella fastidiosa, zinc and, S4.85

Xylella fastidiosa on grape and, S4.147

Biofungicide

new generation of based on Bacillus amyloliquefaciens strain D747, S4.53

for Rhizoctonia solani on rice, screening for, S6.2

Biological control

of Ailanthus altissima, Verticillium nonalfalfae

for, S4.62

of apple replant disease, Brassicaceae seed meal

for, $\mathrm{S} 4.77$

of Aspergillus flavus

atoxigenic strains of Aspergillus flavus for,

$\mathrm{S} 4.58, \mathrm{~S} 4.89, \mathrm{~S} 4.133$

on corn, role for mating type in, S4.28

of Canada thistle, Puccinia punctiformis for, S3.1 of chestnut blight fungus, Cryphonectria hypo-

virus 1 for, 1161

of Clavibacter michiganensis subsp. michiganensis on tomato, production of DAPG and $\mathrm{HCN}$

by Pseudomonas sp. LBUM300 and, 967

of Cryphonectria parasitica, Lysobacter enzymogenes for, S4.90

of Erysiphe necator

Ampelomyces quisqualis for, $\mathrm{S} 4.68$

Ampelomyces spp. for, 707

of foodborne human pathogens, screening of

fresh produce for agents against, S4.30

of Fusarium graminearum on wheat Bacillus amyloliquefaciens for, S4.26 Cryptococcus flavescens for, S5.8

of Fusarium oxysporum f. sp. niveum on watermelon, Streptomyces lydicus for, S4.53

of grapevine crown gall, Rhizobium vitis (nonpathogenic) for, S4.62

of ground ivy, Sclerotinia isolate for, S4.96

of Jaragua grass, S6.5

of leaf miner and nettle caterpillar on oil palm,

Crematogaster ants for, S4.87

of Macrophomina phaseolina on flowering

dogwood, S4.74

microbial-induced carbon competition in the spermosphere leads to pathogen and disease suppression in a municipal biosolids compost, 588

of mile-a-minute, Colletotrichum gloeosporioides for, S3.1

of Monilinia fructicola, screening plum for resident bacteria with biocontrol activity against, $\mathrm{S} 4.58$

of pale cyst nematode, $\mathrm{S} 4.137$

of Phakopsora pachyrhizi on soybean, Simplicillium lanosoniveum for, 749

of Phoma exigua var. exigua on chicory, Trichoderma spp. for, $\mathrm{S} 4.8$

of Phytophthora spp.

P. capsici: on chili pepper, $\mathrm{S} 4.50$; on squash,

Bacillus subtilis IN937b for, S4.8

P. cryptogea on chicory, Trichoderma spp. for, $\mathrm{S} 4.81$

$P$. parasitica var. nicotianae on tobacco, 267

of Pierce's disease on grape, benign strain of

Xylella fastidiosa for, $\mathrm{S} 4.55$

of Pseudomonas syringae pathovars on sweet

cherry, Streptomyces lydicus for, S4.2

of Ralstonia solanacearum on tomato, Bacillus

subtilis biofilm formation and, S4.21

of Rhizoctonia solani on rice, S4.144, S6.2

of Sclerotinia sclerotiorium

application of selected fungal endophytes and

Coniothyrium minitans for, S4.12 on soybean, S5.4

of Sirex spp., S4.87

systemically induced resistance and microbial

competitive exclusion and, 260

of Verticillium dahliae on chili pepper, S4.50

of Xanthomonas axonopodis pv. vesicatoria on

tomato, Asophyllum nodosum extracts for, S3.2

Biological control agents

Afla-Guard

Aspergillus flavus diversity in fields treated

with, S2.9

for management of aflatoxin in corn, S4.133

Ampelomyces spp., for Erysiphe necator, 707,

S4.68

Asophyllum nodosum extracts for control of

Xanthomonas axonopodis pv. vesicatoria on tomato, S3.2

Aspergillus flavus (atoxigenic)

for management of Aspergillus flavus, S4.58,

S4.89, S4.133

sporulation and field movement of, S6.2

Bacillus amyloliquefaciens, for Fusarium graminearum on wheat, S4.26
Bacillus subtilis

antifungal compounds from, S1.8

for control of Phytophthora capsici on squash, S4.81

genomic comparison of strains AS 43.3 and

$\mathrm{OH} 131.1, \mathrm{~S} 4.32$

for Rhizoctonia solani on rice, $\mathrm{S} 4.144$

Brassicaceae seed meal for control of apple

replant disease, $\mathrm{S} 4.77$

Colletotrichum gloeosporioides for control of mile-a-minute, S3.1

Crematogaster ants, for control of leaf miner and nettle caterpillar on oil palm, S4.87

Cryphonectria hypovirus 1 , for control of

chestnut blight fungus, 1161

Cryptococcus flavescens, for control of Fusarium

head blight on wheat, S5.8

for ground ivy, S4.96

for Jaragua grass, S6.5

Lysobacter enzymogenes, for control of Cryphonectria parasitica, $\mathrm{S} 4.90$

new generation of bacterial biofungicides based on Bacillus amyloliquefaciens strain D747,

S4 53

for pale cyst nematodes, $\mathrm{S} 4.137$

Pseudomonas chlororaphis strain 30-84 differential regulation of phenazine biosynthesis by RpeA and RpeB in, S4.130

phenazine structural derivatives, fungal inhibition and biofilm formation and, S4.141

Pseudomonas fluorescens

defense gene induction by, S6.10

in vitro activity against phytopathogenic microorganisms, S4.119

for Pseudoperonospora cubensis on organic cucumber, S1.5

Puccinia punctiformis for control of Canada thistle, S3.1

reviewing in EPA, S4.154

Rhizobium vitis (nonpathogenic) for control of grapevine crown gall, S4.62

for Rhizoctonia solani on rice, S6.2

for Sclerotinia sclerotiorium on soybean, S5.4

screening of fresh produce for agents against

foodborne human pathogens, S4.30

screening plum for resident bacteria with biocontrol activity against Monilinia fructicola, S4.58

Simplicillium lanosoniveum, for Phakopsora pachyrhizi on soybean, 749

Streptomyces lydicus

for management of Fusarium oxysporum $\mathrm{f}$ sp. niveum on watermelon, S4.53

for Pseudomonas syringae pathovars on sweet cherry, S4.2

Trichoderma spp.

for control of Phoma exigua var. exigua and Phytophthora cryptogea on chicory, S4.81

gliotoxin and, S6.3

for Verticillium dahliae and Phytophthora capsici on chili pepper, $\mathrm{S} 4.50$

Verticillium nonalfalfae for control of Ailanthus altissima, $\mathrm{S} 4.62$

Xylella fastidiosa (benign strain) for control of

Pierce's disease on grape, S4.55

Biopesticides. See Biological control agents

Biopolymer coatings, for management of Pseudo-

monas savastanoi on olive, $\mathrm{S} 4.39$

Bipolaris spp.

azoxystrobin-resistant, alternative mechanisms of, S4.120

B. sorokiniana, microsatellite markers for, $\mathrm{S} 2.3$

on switchgrass, pathogenicity, virulence, and impact on biomass, S4.36

Birch, Japanese. See Betula platyphylla var. japonica

Birla, K., 298, S4.12, S5.2

Bissonnette, K. M., S6.7

Bitas, V., S4.12 
Bitsadze, N., S4.12

Bittner, R., S4.12

Bjornson, M. L., S4.100

Black root rot disease complex, on strawberry,

fungicides and mustard meal for management of, S4.72

Black walnut. See Juglans nigra

Blackberry. See Rubus spp.

Blackberry chlorotic ringspot virus (BCRV), TaqMan qPCR detection of, S4.53

Blagden, T., S4.155

Blair, J. E., S1.2, S4.76

Bland, W. L., 519

Blandón-Díaz, J. U., 323

Block, C., S4.12

Block, C. C., S4.101

Blomquist, C., S4.90

Blueberry. See Vaccinium spp.

Blueberry necrotic ring blotch virus (BNRBV) in blueberry, S4.17, S4.101 unique genus of plant RNA viruses, S4.96

Bluegrasses. See Poa annua; Poa pratensis

Bluhm, B. H., S2.6, S2.9, S4.38

Blumeriella jaapii

on flowering cherry, in Tennessee, S4.60 on tart cherry

boscalid resistance and, S5.8

effects on photosynthesis in foliage, 656

BNRBV. See Blueberry necrotic ring blotch virus

Bock, C. H., S4.13

Bockus, W. W., S5.3

Bocsanczy, A. M., 185

Boddu, J., S4.146

Boehm, M. J., S1.1

Boennighausen, J., S4.146

Bogdanove, A., S4.127

Bohannon, R., S4.143

Bohannon, S., S4.143

Boiteux, L. S., S4.105

Boland, G. J., S4.121

Bolton, M., S4.12

Bolton, M. D., 298, S5.2

Bombecini, J., S4.13

Bonants, P., 635, S4.155

Bond, J., S4.138

Bond, J. P., S4.11, S4.57, S4.112, S5.4

Bonde, M. R., 761, S4.13

Bonello, P., S4.65, S5.2, S5.3, S5.9

Bonman, J., S4.145

Bonman, J. M., 390

Boraks, A., S4.13

Borhan, H., S4.113

Bormann, J., S4.146

Borowicz, P., S5.4

Borth, W., S4.131

Borth, W. B., 122, S1.6

Boscalid

for Alternaria solani on potato, detection of resistance, $\mathrm{S} 4.36$

for Blumeriella jaapii on tart cherry, resistance to, S5.8

for Didymella bryoniae on watermelon, sensitivity of Florida isolates, S4.52

Bost, S., S4.14

Bostic, L., S4.14

Bostock, R. M., S4.95, S4.100, S4.103, S4.139,

S4.160, S6.12, S6.13

Bothe-Goralczyk, M. A., S1.7

Botryosphaeria spp.

B. dothidea

on apple, S4.127

on blueberry, S4.111

effects of phenolic compounds on reduction of growth and laccase, S4.113

Botrytis spp.

on blackberry

characterization and detection of new species, $\mathrm{S} 2.7$

in southeast United States, S4.68
B. cinerea

on apple: endogenous ethylene biosynthesis and resistance to, 135; Lamiaceae essential oils for control of, S4.112; molecular characterization of pyraclostrobin resistance and structural diversity of the cytochrome $b$ gene in, 315

on blueberry, sulfur dioxide for control of, S4.100

distribution and molecular characterization of isolates resistant to respiration inhibitors, $\mathrm{S} 2.3$

fluopyram resistance development in, S4.84

on grape: comparative analysis of techniques for detection of, S4.104; prebloom leaf removal for control of, S4.52

mechanisms of resistance to respiration inhibitor fungicides in, S4.4

on Solanum lycopersicoides, molecular and biochemical characterization of resistance, S2.9

on strawberry: characterization of isolates resistant to multiple fungicides, S4.38; deection and molecular characterization of fenhexamid resistance in, $\mathrm{S} 4.47$; recent epidemic in Florida, S4.4; resistance to multiple fungicides, S4.4

Trichoderma harzianum ETS 323, antagonism of ony mycelium in culture conditions, 1054 on strawberry

characterization of isolates resistant to multiple fungicides, S4.38

detection and molecular characterization of fenhexamid resistance in, $\mathrm{S} 4.47$ recent epidemic in Florida, S4.4 resistance to multiple fungicides, $\mathrm{S} 4.4$ in southeast United States, S4.68

Bottner-Parker, K. D., S4.8

Bouzar, H., S4.103

Bové, J. M., S4.138

Bowden, R. L., S4.61

Bowen, C. R., S4.21, S4.51, S4.134

Bowen, K. L., S2.5, S2.9, S4.14, S4.18, S4.49, S4.115

Bowman, H., S4.15, S4.97, S4.156

Bowman, L., S4.165

Boxwood. See Buxus spp.

Boyd, L. A., S4.16

Boyle, M., S4.50

Boyle, S., S4.85

Boyles, M. C., S4.28

Boyzo-Marín, J., S4.15

Bozan, O., 1168

Bozorgmagham, A., S3.4

BPMV. See Bean pod mottle virus

Brachiara, Rhizoctonia solani AG-1 IA on, in

Colombia, S4.97

Brachypodium distachyon

Cochliobolus sativus on, $\mathrm{S} 4.3$

as model system for studying disease in cereal crops, S4.143

Puccinia emaculata on, nonhost resistance, $\mathrm{S} 4.123$

Bradeen, J., S4.15

Bradeen, J. M., S4.6, S4.15, S4.42

Bradley, C., S5.7, S5.8

Bradley, C. A., S4.2, S4.21, S4.102, S4.133, S4.135,

S4.143, S4.157, S5.4

Bradysia impatiens (fungus gnat), as vector of

Pythium aphanidermatum and P. ultimum on geranium, 283

Branch, W. D., S2.2, S2.8

Brannen, P., S4.55

Brannen, P. M., S4.101

Brantner, J. R., S4.16, S4.136

Brassica spp.

for control of Rhizoctonia solani on rice, S6.2 cover crops, for Rhizoctonia solani on rice, S4.144
B. juncea, for control of apple replant disease, $\mathrm{S} 4.77$

B. napus (canola, oilseed rape)

Leptosphaeria maculans on: in seed and dockage, S4.38; timing of inoculation and, S4.28; wide hybridization for resistance transfer into, S4.136

Leptosphaeria spp. on, diagnostic assay for, S4.12

Pyrenopeziza brassicae on, reduced azole sensitivity of, S4.19

Sclerotinia sclerotiorum on, fungal gene expression patterns during infection, S4.23

B. oleracea, clubroot in, salicylic acid suppression of, S4.72

Plasmodiophora brassicae on, comparison of host resistance and, $\mathrm{S} 4.78$

Brassicaceae seed meal (SM), for apple replant disease, S4.77

Braun, S. E., 283

Breeding, marker assisted. See Marker-assisted

breeding

Bremmer, J., 609

Brennan, M., S4.91

Brenneman, T. B., S2.1, S2.4, S2.6, S2.7

Brenneria rubrifaciens, AHL signals, rubrifacine production and, 195

Bressan, A., S4.16, S4.18, S4.132

Breukers, A., 609

Brewer, M. T., 997, S4.16

Briere, S. C., S4.12

Bright, D. B., S4.59

Brlansky, R., S4.55

Brlansky, R. H., S4.24, S4.103, S6.1, S6.3

Broders, K., S4.13, S4.91

Broders, K. D., S4.160

Bromus laevipes, epichloid endophytes of, S4.117

Broome, J. C., S4.91

Brosnan, J. T., S4.11

Brouwer, H., 348

Brown, D., S4.104

Brown, H. M., S4.76

Brown, J. K., S4.5, S4.39, S4.51, S4.52, S4.56, S4.164

Brown, L. G., S4.163

Brown, R., S4.84

Brown, R. L., S4.40

Brownbridge, M., S4.93

Browne, G., S4.10

Browne, G. T., S4.16, S4.31, S4.106

Bruckart, W. L., S3.2, S4.16

Brueggeman, R., S4.145, S5.4

Brunelli, A., 1130

Bruns, T. L., S4.142

Brunson, B., S2.1

Brus, M., 878

Bryan, G., S4.120

Bryant, R., S4.16

Brychkova, G. G., S4.81

Bryner, S. F., 1161

Bryson, P., S4.38

BSMV. See Barley stripe mosaic virus

Buchnera GroEL from, Pentalonia nigronervosa, interaction with Banana bunchy top virus and, S4.132

Buck, J., S4.31

Buck, J. W., S4.125

Buckley, B., S4.99

Budahn, H., S4.136

Budakov, D. B., S4.115

Buddha hand. See Citrus medica var. sarcodactylis

Buehring, N., S4.3

Buell, C., S1.5, S4.113

Buell, C. R., S4.34

Buffalograss, Cercospora seminalis on, genetic diversity of, S4.4

Buiate, E. A., S4.17, S4.120, S4.138

Buitrago, C., S4.88

Bull, C. T., S4.103 
Bulluck, R., S4.59, S4.60, S4.90

Burbank, L., S4.17

Burchhardt, K. M., S4.17

Burelle, N. K., S4.153

Burgos-Garay, M. L., S1.2

Burkholderia spp.

B. glumae

on rice: antagonistic activities of rice-associated bacteria, S2.8; comparative genomic analysis of, S2.4; genetic and phenotypic variations among strains, S2.6; genetic dissection of regulatory network controlling virulence, S2.5; global regulatory network for virulence of, S4.148; naturally occurring avirulent strains, S4.62; non-thermal plasma seed treatment for control of, S6.1; quantification of yield losses caused by, S4.144; regulation of the virulence factors by the TofI/TofR quorum-sensing system, S2.2; tof $M$ and quorum-sensing independent biosynthesis of toxoflavin, S4.22

transposon mutagenesis of $336 \mathrm{gr}-1$, toxoflavin production and, S2.8

on rice, genomic island-based plasticity among genomes of, S4.41

Burkle, C., S4.17

Burlacu, V., S4.2

Burlakoti, R., S4.17

Burlakoti, R. R., S4.17

Burnett, A., S1.2

Burnett, A. L., 421, S1.4

Burns, B., S4.84

Burns, D., S2.5

Burr, T., S4.59

Burris, E., S2.5

Burrows, M., S6.13

Buttercup, creeping. See Ranunculus repens

Butternut. See Juglans cinerea

Buxus spp. (boxwood), Calonectria pseudonaviculata on, real-time PCR for detection of, S4.26

Buyer, J., S4.100

Buyer, J. S., S3.4, S4.58

Byamukama, E., S4.134, S5.2

Byrne, R., S2.6

Caasi, D. R., S4.20, S4.89

Cabanas, D. R., S4.18

Cabrera, A., S5.5

Cabrera, C. R., S4.15

Cacao. See Theobroma cacao

Cadle-Davidson, L., 65, 83, S4.7, S4.18, S4.104, S4.116

Cadle-Davidson, M., 83

Caesar, A. J., S4.67

Caesar-TonThat, T., S4.67

Caffi, T., 158, 707, S4.68

Cahill, D., S4.72

Cahill, D. M., S4.81

Cai, C. M., S4.37

CAI, G., S1.2

Cai, G., S1.4, S4.93

Cai, L. T., 267

Cai, R., S4.160

Cai, X., S4.148

Caiazzo, R., S4.18

Calacarus sp., Blueberry necrotic ring blotch virus and, S4.17

Calcium

fungal virulence in plants and humans and, S5.3 Xylella fastidiosa and, S4.27, S4.36

Calderón, C., S4.18

Callery pear. See Pyrus calleryana

Callicott, K. A., S4.89

Callosobruchus maculatus, insecticidal plants and organic flowers as inert carriers in controlling cowpea against, $\mathrm{S} 4.88$

Calonectria pseudonaviculata, on boxwood, realtime PCR for detection of, S4.26

Cambra, M., 114
Camelina sativa

Hyaloperonospora camelinae on, in Washington state, S4.8

Peronospora parasitica on, S4.114

Campbell, A., S4.19

Campbell, H. L., S4.14, S4.18, S4.49

Campbell, J., S6.1

Campbell, L. G., S4.136

Camuzeaux, D., S4.84

CaMV. See Cauliflower mosaic virus

Canada thistle. See Cirsium arvense

CANARY assay

overview of, S4.156

for Phytophthora spp., S4.15

for Ralstonia solanacearum isolates, S4.97

Canas, L., S4.144

Candidatus Liberibacter spp.

$\mathrm{Ca}$. L. americanus, genomic evaluation of strain São Paulo, S4.138

Ca. L. asiaticus

alternative hosts for, S6.3

cellular interactions and transcript profiling during psyllid infection and vector-mediated transmission, S4.39

on citrus, nutritional supplements in management of, S6.2

comparative genomic analysis of interactions with psyllids, S4.164

effect of citrus juice on viability of, S2.10

evolving diversity mediated by frequent

recombination and reassortment of prophages of, S4.144

genes orthologous with pSymA-borne genes of Sinorhizobium meliloti, S3.3

genetic diversity in southwest Asia and South America, S6.5

microsatellite-based genetic diversity and structure of worldwide populations, S6.3

novel autotransporters encoded by, S4.50

population diversity revealed by tandem repeat number variation in a hypervariable genomic locus, S4.74

putative virulence factors of, S4.141

RNA sequence analysis in citrus and in psyllid, S4.64

salicylate hydroxylase of, Xanthomonas citri subsp. citri and, $\mathrm{S} 4.121$

stress-induced response of prophage FP1 and

FP2 in, S4.30

survival in different media over time, S4.90

chemotherapy for control of, S4.143

on citrus and potato, physiological and proteomic characterization of, S4.71

ecological niche assessment of, S6.6

graft-based chemotherapy method for screening

effective molecules and rescuing affected

plants, 567

primers and probes for genus-specific detection of, S6.1

Ca. L. solanacearum

cellular interactions and transcript profiling during psyllid infection and vector-mediated transmission, S4.39

comparative genomic analysis of interactions with psyllids, S4.164

effect of on fitness of insect vector, Bactericera cockerelli on tomato, 41

effects of temperature on gene expression in, S4.164

loop-mediated isothermal amplification procedure for detection of in potatoes and psyllids, 899

on potato: effects of pathogen titer, vector numbers, and feeding sites, 1079; genetic characterization of strains in Washington and Idaho, S4.134; genotyping and population genetic analysis of, S4.71; psyllid source assessment in Pacific Northwest, S4.137; shifts in physiology after infection with, S4.129; translocation and quanti-

fication of, S6.4

on tomato, translocation and quantification of, S6.4

Candidatus Phytoplasma spp.

relatedness to phytoplasmas causing grapevine

yellows disease in eastern United States, S4.29 survey for in Nevada, S4.84

Canola. See Brassica napus

Cantaloupe. See Cucumis melo

Cantao, F., S4.152

Canteros, B. I., S4.45

Cantet, M., S2.5

Cantonwine, E. G., S2.2

Cantúa, J., S4.139

Cape gooseberry. See Physalis peruviana

Caplan, J. L., S4.55

Capsicum sp. (pepper)

C. annuum (jalapeño pepper), Streptomyces spp. on, electrophoretic profiles of peroxidases and polyphenol oxidases and, S4.46

C. annuum (pepper, chili pepper) cover crops and increased yields following, S4.49

incidences of viruses infecting in Mexico, S4.101

Phytophthora capsici on: correlation of host resistance with fruit traits, S4.85; effect of two inoculants on, S6.12; screening for biocontrol agents for, $\mathrm{S} 4.50$; in southern France, S2.5

Potato virus $Y$ in, $\mathrm{S} 1.4$

Tobacco etch virus in, strains inducing different disease phenotypes, S4.84

Verticillium dahliae on: examination of race structure in New Mexico, S4.50; screening for biocontrol agents for, $\mathrm{S} 4.50$

volatile organic compounds produced by London rocket and flixweed for control of, S6.12

Xanthomonas spp. on, cymoxanil and famoxadone for management of, S2.3

Tobacco etch virus (nonwilting strain) in, isolate overcoming two resistance genes, S4.127

Carballo, V., S5.9

Carbon dioxide, Alternaria leaf spot and black spot on basil and, S4.94

Carbone, I., S1.1, S4.95

Cárdenas, M., S4.18

Carica papaya (papaya), breeding for resistance to

Papaya root spot virus, $\mathrm{S} 4.129$

Carlton, C., S4.87

Carputo, D., S4.15

Carrot. See Dauca carota

Carter, H., S4.19

Carter, M. L., S4.73

Cartwright, R., S4.59

Cartwright, R. D., 700

Caruso, F. L., S4.19

Carya illinoensis (pecan)

Colletotrichum gloeosporioides on, asymptomatic foliar infections, S2.6

Fusicladium effusum on effect of height on disease severity, S4.13 ground application of fungicide for control of, S4.13

Castagnone-Sereno, P., 990

Castanea sativa (chestnut), Cryphonectria parasitica on, in Lebanon, S4.104

Castiblanco, L. F., S4.19

Castillo, H. A., S4.43

Castillo, Y. V., S4.80

Casuarina equisetifolia (ironwood), wood decay

fungi of, in Guam and Saipan, S4.106

Cating, R. A., S4.19

Cauliflower mosaic virus (CaMV), CHUP1 and

inclusion body assembly in, S4.6

Cavatte, P. C., 892

Cavin, C. A., S3.1 
CbCyp51 gene, Cercospora beticola on sugar beet and, 298, S4.12

CBS Culture Collection, overview of, S4.167

CDiT1 protein, Pyrenochaeta lycopersici on tomato and, 878

Ceibo. See Erythrina crista-galli

Celery. See Apium graveolens

Cellulase, characterization of bacteria producing, in

Thailand soils, S4.105

Celtis laevigata (sugarberry), novel ampelovirus

associated with, S2.11

Centipedegrass. See Eremochloa ophiuroides

Cepeda, M. V., S5.2

Ceratocystis fimbriata, volatile organic compounds produced by, growth of soilborne Rhizoctonia

solani and rice seed germination and, S4.70

Cercospora spp.

C. apii, on celery, fungicides for management of, S4.97

C. arachidicola, on peanut new runner-type cultivars, S2.8 penthiopyrad and pyraclostrobin for, S2.2

C. beticola, on sugar beet

CbCyp 51 gene from, $\mathrm{S} 4.12$

characterization of CbCyp51 from, 298

fungicide resistance in, S5.2

host sensing, stomatal tropism, initiation of stomatal penetration and, S2.6

C. coffeicola, on coffee, in three cropping systems, $\mathrm{S} 4.112$

genes conferring resistance to photoactivated

toxin cercosporin from, $\mathrm{S} 4.11$

C. hydrangeae, on hydrangea, light density and

host resistance, $\mathrm{S} 4.70$

C. janseana, on rice

effect of planting date, fungicide timing, and varietal susceptibility levels, S4.75

planting date, fungicide timing, varietal tolerance and, S2.6

C. kikuchii, on soybean

application timing and rates of application of demethylation inhibitor fungicide for, $\mathrm{S} 4.107$ effects of variety, inoculum source, and environment, S4.99

C. seminalis, on buffalograss, genetic diversity of, S4.4

C. sojina, on soybean, characterization of QoI

fungicide-resistant and sensitive isolates, S4.143

C. zeae-maydis, on corn

effects of hybrid and foliar fungicide on disease severity and yield, S5.7

host sensing, stomatal tropism, initiation of stomatal penetration and, S2.6

Cercosporidium personatum, on peanut

evaluation of ICRISAT varieties for resistance to, S2.4

evaluation of recombinant inbred line (RIL) derived lines for resistance, S2.4

new runner-type cultivars, S2.8

Cercosporin

genes conferring resistance against, S4.11

role of the $\mathrm{ABC}$ transporter ATR1 in resistance to, $\mathrm{S} 4.53$

Ceresini, P. C., S4.38, S4.97

Cernadas, A., S4.127

Certification programs

citrus spp. and use of young indicator plants and, S4.67

five common pests in nurseries participating in different programs, S4.89

potato seed and Potato virus Y, S4.149

proficiency test results summary for the 2011

National Plant Protection Laboratory Accredi-

tation Program (NPPLAP) citrus greening

(huanglongbing) detection assay, S4.108

Cervone, T. R., S4.20

Cevallos-Cevallos, J. M., S4.99, S4.126

Cevallose-Cevallos, J. M., S4.48

Cha, B., S4.63
Chai, Y., S4.21

Chakrabarty, P. K., S4.138

Chakraborty, S., S5.2

Chalam, C., S4.6, S4.20

Chalupowicz, L., 23, S4.20

Champaco, E. R., S4.20

Chanda, A. K., 749

Chang, P., S2.9

Chao, S., 94, S4.72, S4.145

Chapados, J. T., S4.22

Chapara, V., S4.21

Chapman, J. R., 1034

Charkowski, A. O., S4.42, S4.77, S4.147

Charlton, N., S4.21, S4.117

Charlton, N. D., S4.160

Chastagner, G. A., S6.8

Chatterton, S., S6.11

Chauhan, K., S4.66

Chaves, A., S4.45

Chaves, A. R. M., 892

Chawla, S., S4.21

Chellemi, D. O., 597

Chemotherapy

for Candidatus Liberibacter in field, S4.143

for screening for compounds effective against huanglongbing in citrus, 567

Chen, C., S5.3, S5.5

Chen, F., S2.3, S4.21

Chen, F. P., S2.2

Chen, J., 816, S4.22, S4.68, S4.74, S4.129

Chen, K., S2.7

Chen, L., S4.19, S4.22

Chen, M.-H., 478, 588

Chen, Q. Y., 267

Chen, R., S2.2, S2.5, S2.8, S4.22

Chen, S., S4.165

Chen, W., S1.5, S4.7, S4.22, S4.64, S4.95

Chen, X., S2.3, S4.22, S4.30, S4.63, S4.130, S4.132

Chen, Y., S4.21, S4.22, S4.25, S4.144

Chen, Z., S2.4, S4.40, S4.99, S4.150

Cheng, C.-H., 1054

Cheng, P., S4.22

Chenopodium quinoa (quinoa), Peronospora variabilis on, S1.7, S4.118

Cherry. See Prunus spp.

Cherry leafroll virus (CLRV)

genetic diversity of coat protein from different hosts, S4.79

multiplex RT-PCR for identification of, S4.20 in walnut, in California, S4.74

Cherry twisted leaf associated virus (CTLaV), in

cherry and apricot, S4.128

Chervil. See Anthriscus cerefolium

Chestnut. See Castanea sativa

Chestnut, S. L., S4.23

Chewachong, G., S5.3

Chiara, M., S4.120

Chickpea. See Cicer arietinum

Chicory. See Cichorium intybus

Chien, M., S3.2

Chigne, A., S4.118

Chikh Ali, M., S4.23

Childers, R., S4.84

Childers, R. A., S4.28

Chili pepper. See Capsicum annuum

Chilvers, M., S4.45

Chilvers, M. I., S4.102, S4.131, S4.132, S5.8

Chinese eaglewood. See Aquilaria agallocha

Chingandu, N., S6.8

Chiroleu, F., 733

Chitosan, for control of Phytophthora capsici on

tomato, $\mathrm{S} 4.80$

Chittem, K., S4.23

Chiusano, M. L., S4.15

Chiyaka, C., S4.23

Chlorine, organic, for Penicillium expansum on

apple, S4.125

Chlorine dioxide, for disinfecting fungi in wheat seeds, S4.59
Cho, S., S4.85, S4.146

Cho, Y., S4.24

Choi, H., S4.63

Choi, K., S4.24, S4.89

Choo, T.-M., 683

Chopra, S., S4.138

Choudhary, N., S4.24, S4.103

Choudhury, R. A., S4.24, S4.25, S6.8

Chow, V., S4.108

chp/tomA pathogenicity island, Clavibacter michi-

ganensis subsp. michiganensis on tomato and, 23

Chrysanthemum spp., Fusarium oxysporum f. sp.

chrysanthemi on, comparison of cultivar sensitivity, S1.2

Chuma, I., 674

CHUP1, Cauliflower mosaic virus inclusion body

assembly and, S4.6

Church, G., 597

Cianzio, S., S4.1

Cicer arietinum (chickpea)

Ascochyta rabiei on, solanopyrone production and, S4.64

Sclerotinia sclerotiorum on, transcriptome analysis using RNA sequencing, S4.95

Sclerotinia trifoliorum on, transcriptome analysis of interaction, S4.95

Cicero, J. M., S4.39

Cichorium intybus (chicory), Phytophthora cryptogea

and Phoma exigua var. exigua on, S4.41, S4.81

Cilantro. See Coriandrum sativum

Cilia, M. L., S4.164

Cirsium arvense (Canada thistle), Puccinia

punctiformis on, $\mathrm{S} 3.1$

Cisneros, F., S4.25

Citrullus lanatus (watermelon)

var. citroides, lines with improved resistance to

Fusarium oxysporum f. sp. niveum race 2 ,

S4.133

Acidovorax citrulli on

influence of pathway of bacterial invasion on localization in seeds, 461

localization in seeds, pathogen detection and transmission, S2.10

Didymella bryoniae on, sensitivity of Florida isolates to boscalid, S4.52

Fusarium oxysporum f. sp. niveum on, Vicia villosa green manure and Streptomyces lydicus for management of, S4.53

grafting of, for management of Fusarium oxysporum f. sp. niveum., S4.153

Pseudomonas syringae on, $\mathrm{S} 4.103$

Sphaerotheca fusca on

alternative spray schedule of fungicides and potassium phosphonate for control of, S4.61

control using egg yolk and cooking oil, S4.61

Squash vein yellowing virus in, resistant pollinizers and, S4.65

virus movement within grafted plants, S4.133

Citrus leprosis virus (CiLV-C)

in citrus, in Colombia, S4.103

monoclonal antibodies to expressed coat protein of, immunodiagnosis and, $\mathrm{S} 4.24$

Citrus psorosis virus (CPV), immunoassay for detection of, S4.97

Citrus spp.

Candidatus Liberibacter spp. on

$\mathrm{Ca}$. L. asiaticus on, RNA sequence analysis, S4.64

physiological and proteomic characterization of, S4.71

certification programs for, $\mathrm{S} 4.67$

Citrus leprosis virus in, in Colombia, S4.103

Citrus viroid III in, in northeastern Mexico,

S6.2

development of high-throughput assays for rapid and accurate 10-plex detection of pathogens of, S4.131 
Elsinö̈ spp. on

E. australis, in Texas, S4.110

E.fawcettii, fungicide application for control of sporulation, $\mathrm{S} 4.82$

Guignardia citricarpa on

baseline sensitivity to strobilurin fungicides, S4.53

copper sensitivity of Florida isolates, S4.52

nutritional and environmental effects on germination and appressorium formation, S4.13

postharvest symptom development and

viability of conidia, S4.35

huanglongbing on

first report in Texas, S4.66

graft-based chemotherapy method for screening effective molecules and rescuing affected plants, 567

thermal treatments for suppression or elimination of, S4.31

Xanthomonas citri subsp. citri and, S4.121

C. jambhiri (rough lemon), ACRTS1 gene

encoding hydroxylase involved in biosynthesis

of ACR toxin in, 741

C. japonica (kumquat), Xanthomonas citri pv.

citri on, comparative analysis of oxidative

management in, $\mathrm{S} 4.33$

C. limon (lemon), Citrus yellow vein clearing

virus (CYVCV) in, 1168

C. medica var. sarcodactylis (Buddha hand),

Xanthomonas citri pv. citri on, S4.66

C. x paradisi (grapefruit), Xanthomonas citri pv. citri on, comparative analysis of oxidative management in, S4.33

Phytophthora nicotianae on, volatile compounds produced by saprophytic fungi and, S4.99

phytoplasmas and rod-shaped bacteria associated with disease of unknown etiology in Mexico, S6.5

prevalent diseases of in Puerto Rico, S6.4 screening for resistance to huanglongbing, S4.63

Spiroplasma citri on, incidence and spatial temporal distribution, S4.141

Stenotrophomonas spp. and Alcaligenes faecalis on, in Iran, S4.3

C. tangerina (tangerine), Alternaria alternata on, geographic and cultivar distribution of QoI-

resistant isolates, $\mathrm{S} 4.127$

C. volkameriana, Hibiscus green spot virus in, 122

Xanthomonas citri subsp. citri on

$h m s F$ as virulence factor of, $\mathrm{S} 4.130$

huanglongbing infection and, S4.121

$n l x A$ gene and production of lipopoly-

saccharide and extracellular polysaccharide, motility, biofilm formation, and stress resistance, S4.140

predisposition of foliage to infection with, S4.13

TAL effector PthA4-mediated virulence and host gene induction, S4.55

Citrus tristeza virus (CTV), calculation of diagnostic parameters of advanced serological and molecular tissue-print methods for detection of, 114

Citrus viroid III (CVd-III), occurrence in northeastern Mexico, S6.2

Citrus yellow vein clearing virus (CYVCV), in

lemon, 1168

Cladosporium spp., current concepts, diversity, and

taxonomy of, S4.162

Clark, C., S4.28

Clark, C. A., S2.2, S2.10, S2.11, S4.138

Clark, M. M., S4.92

Clark, S., S6.13

Clarke, B. B., S1.1, S1.3, S1.6, S1.7

Clavibacter michiganensis

subsp. michiganensis

gaseous ozone treatments for elimination of on greenhouse surfaces, S5.10

GFP-labeled, colonization and movement of during tomato infection, 23 saprophytic bacteria reacting with in seed

health testing, S4.115

on tomato: colonization under different

humidity regimes, 177; LAMP assays for

detection of, S4.141; production of DAPG

and HCN by Pseudomonas sp. LBUM300

and biological control, 967

subsp. nebraskensis, on corn

alternate hosts for, S5.6

effects on grain quality and seed infection, S4.101

factors affecting development and severity of, S5.6

infection through natural openings, S4.75

in Minnesota, S4.75

Claviceps purpurea, on Kentucky bluegrass,

preconditioning cold treatments and incubation temperature and, S4.123

Clay, B., S4.104

Clayton, L. A., S4.61

Clergeot, P.-H., 878

Cleveland, K., S5.3

Cleveland, K. M., S4.44

Clifford, J., S4.147

Climate conditions

Alternaria leaf spot and black spot on basil and, S4.94

ascocarp formation by Podosphaera aphanis on strawberry and, S4.7

Botryosphaeria dothidea and Diplodia seriata on blueberry and, S4.111

Candidatus Liberibacter solanacearum gene expression and, S4.164

Colletotrichum spp. and

C. cereale, on annual bluegrass, temperature and appressorium formation, S4.132 on olive, 974

colonization of Clavibacter michiganensis subsp. michiganensis on tomato and, 177

colonization of Guignardia psidii on guava and, S4.25

Erysiphe necator on grape and, 857

Fusarium graminearum and perithecial development on the straws decomposed in different soils, S2.9, S4.115 variability in epidemics and, 55 on wheat and deoxynivalenol production, S4.5

Fusicladium carpophilum on nectarine and, 421

Guignardia bidwellii on grape, fungicide application and, S4.111

herbivory of purple marsh crab on Spartina alterniflora and, S1.3, S4.34

Macrophomina phaseolina growth and development and, S5.9

Magnaporthe oryzae on perennial ryegrass and, S1.5

modeling of, reliability and accuracy of in

Pennsylvania, S4.49

Neofusicoccum parvum on blueberry and, S4.34

Phakopsora pachyrhizi on soybean and, 761, 794, S4.13

Populus tremuloides mortality and, S4.137

Puccinia spp. and

$P$. graminis subsp. graminis $\mathrm{f}$. sp. tritici on wheat, effect on latent period across isolates from different cultivars, $\mathrm{S} 4.52$

$P$. striiformis on wheat, boosted regression trees to evaluate impacts of, S4.47

Ralstonia solanacearum and adaptation and, S4.56

on tobacco, host resistance and, S4.12 virulence and, 185

Rhynchosporium commune adaptation and, S4.114

risk of disease in grapevine and other perennial crops and, S4.42

Sclerotinia homoeocarpa and fungicides and, S4.56, S4.111
Stagonospora nodorum on wheat and, S4.65 sustainable grape pest management using weather data and disease risk models, S4.91

thousand cankers disease on black walnut and, S3.3

virus titer development and population growth of the wheat curl mite in wheat streak-resistant wheat cultivars and, S4.94

Closteroviruses, in ti in Hawaii, S1.6

Clostridium sp., on sweet potato, flooding and, S4.28

Clove. See Syzygium aromaticum

clp gene, Xanthomonas oryzae pv. oryzicola

virulence and, 252

Clp regulator, virulence of Xanthomonas oryzae pv.

oryzicola on rice and, 841

CLRV. See Cherry leafroll virus

Clubroot. See Plasmodiophora brassica

CLVd. See Columnea latent viroid

Coast live oak. See Quercus agrifolia

Coat protein

expression of in Oat blue dwarf virus, $\mathrm{S} 4.33$

genetic diversity of Cherry leaf roll virus from different hosts, S4.79

Wheat streak mosaic virus virion assembly and virus movement, $\mathrm{S} 4.118$

Cobine, P. A., S4.88

Cochliobolus spp.

C. miyabeanus, on rice, predisposition factors affecting disease development in, S4.74

C. sativus on barley: sensitivity of 1050 accessions, $\mathrm{S} 4.3$; unique genomic region of pathotype 2 and virulence of, $\mathrm{S} 4.68$

on Brachypodium distachyon, $\mathrm{S} 4.3$

Brachypodium distachyon and, as model system for studying disease in cereal crops, S4.143

velvet-like complex and development and virulence of, S5.9

Cochran, A. M., S4.37, S4.139

Cochran, K., S4.25

Cocos nucifera (coconut), Aspergillus flavus on,

detection using ammonia treatment, S4.1

Coelaenomenodera minuta (leaf miner), on oil palm,

S4.87

Coffea arabica (coffee)

center pivot irrigated, rust and brown eye spot on, S4.27, S4.28

Cercospora coffeicola on, in three cropping systems, S4.112

Coffey, M. D., 229, S4.76

Coffin, R. H., S1.5

Coggeshall, A., S6.13

Cogliati, E., S4.94

Cogongrass. See Imperata cylindrica

Coker, C., S4.3

Colletotrichum spp.

C. acutatum

on apple: factors involved in outbreaks, S5.6; in Indiana, S4.64; virulence and genotypic diversity of strains from New Hampshire, S4.91

on blueberry, host defenses, inheritance of resistance, and environmental effects, S4.150

draft genome assembly of, S4.93 on lupin, assessing disease symptoms in Andes, S4.37

pyraclostrobin for treatment of, simulated rainfall to evaluate removal of, S4.46 on strawberry, effect of inoculum concentration on, $\mathrm{S} 4.40$

survival on weeds, S4.41

on tree tomato, in Ecuador, S4.94

C. cereale

on annual bluegrass: mechanical injury and disease severity, S1.3; nitrogen fertilization and, S1.7; temperature and appressorium formation, S4.132 
on creeping bentgrass, temperature and appres-

sorium formation, S4.132

C. chlorophyti, on soybean, $\mathrm{S} 4.140$

C. coccodes, on potato

field flooding for control of, S6.11

organically grown, S4.77

volatile organic compounds for control of, S4.135

C. eremochloae, on centipedegrass, $\mathrm{S} 2.10$

C. gloeosporioides

on apple: factors involved in outbreaks, S5.6; in Indiana, S4.64

on basil, effects of increased $\mathrm{CO}_{2}$ and

temperature on, S4.94

on ceibo, S4.91

for control of mile-a-minute, S3.1

on pecan, asymptomatic foliar infections, S2.6

on sorghum, production practices and anthracnose severity and biomass yield of, S2.5

on strawberry, evaluation of epidemiology and prediction tools of, S4.17

C. graminicola

on maize: secondary metabolite genes and gene clusters of, S4.138; transcriptome analysis of, S4.120

role of fungal stress response in pathogenicity of, S4.17

C. lindemuthianum, on bean, phenotypic

variability in populations, 490

on mango and tree tomato, in Colombia, S4.18 on olive

effect of temperature, wetness duration, and planting density on, 974

mummified fruit as source of inoculum, 982

on ornamental nursery and landscape plants,

S4.27

on soybean, first report of new species, S4.140

on strawberry, inoculation of leaves for detection

of resistance, $\mathrm{S} 2.8$

C. sublineolum, on sorghum

secondary metabolite genes and gene clusters of, S4.138

silicon supplements, leaf gas exchange and oxidative stress and, 892

Colletti, A. R., S4.25

Collina, M., 1130

Collins, A. A., S1.2

Collmer, A., S4.2

Collmer, C. W., S4.2

Colocasia esculenta (taro), Phytophthora colocasiae on population structure using SNP markers, S4.109 SNP markers for, S2.9

Columnea latent viroid (CLVd), in tomato, in West

Africa, S4.9

Comparative genomics

Candidatus Liberibacter-psyllid interactions and, S4.164

new era for oomycete taxonomy, ecology and

diagnostics and, S1.5

for species resolution in Alternaria spp., S4.162

for studying evolution and speciation in fungi, S4.162

Compartmental models, time-dependent infectivity

and flexible latent and infectious periods in, 365

Competitive exclusion, systemic acquired resistance,

biological control and, 260

Compost, for prunus replant disease, $\mathrm{S} 4.93$

Composted manure soil amendment, Pythium ulti-

mum on sugar beet and, 413

Cong, P., S4.21

Conifers

ectomycorrhiza on seedlings colonized by dark septate endophytes and, S4.98

Heterobasidion irregulare on, seasonal variation

in presence and abundance of inoculum, S4.111

Coniothyrium minitans, for control of Sclerotinia

sclerotiorum, $\mathrm{S} 4.12$
Conlan, X., S4.72

Conley, S. P., S4.135

Conn, K., S4.62

Connell, T., 519

Conrad, A. O., S5.3

Constantelos, C. C., S1.8

Contreras, R., S6.1

Cook, A. Z., S4.13

Cook, D. E., S4.26

Cook, D. J., S4.98

Cooke, D. E., S4.76

Cooking oil, for control of Sphaerotheca fusca on watermelon, S4.61

Cools, H., S4.19

Cools, H. J., S4.41

Coombs, E. M., S4.16

Coop, L., S6.13

Coop, L. B., S4.19, S4.91

Cooper, J., S3.4

Cooper, M. L., S6.13

Copeland, G., S4.59

Copini, P., 827

Copper

for control of foliar bacterial pathogens of

tomato, $\mathrm{S} 4.14$

for control of Guignardia citricarpa on citrus, sensitivity of Florida isolates, S4.52

CorA, regulation of in Pectobacterium carotovorum, S4.32

Coral tree. See Erythrina crista-galli

Cordova-Kreylos, A., S4.119

Cordts, J. M., S4.152

Cordyline fruticosa (ti), closteroviruses infecting, in

Hawaii, S1.6

Coriandrum sativum (cilantro)

Plectosporium tabacinum on, S4.125

Pythium dissotocum, detection of in hydroponic system, S6.5

Corn. See Zea mays

Corn thrips. See Frankliniella williamsi (corn thrips)

Cornus spp. (dogwood)

Macrophomina phaseolina on, bacterial biocontrol agents for control of, S4.74 metagenomic analysis of fungal diversity associated with, S1.6

Corral, R., S4.127

Correll, J., S4.37, S4.59

Correll, J. C., S4.26, S4.38

Cortes-Cueto, A. L., S4.110, S6.6

Cortical tissue, normal destruction of in pine roots,

S4.129

Cortright, B., S5.4

Corylus avellana (European hazelnut), Anisogramma

anomala on

draft genome of, S1.2

microsatellite markers for, $\mathrm{S} 1.4$

Corynespora cassiicola

on cotton, in Alabama, S4.18

on tomato, resistance to respiratory inhibitors in isolates from Florida, S4.2

Costa, J., 306

Costa, L., S4.101

Cotter, H. T., S1.2

Cotton. See Gossypium spp.

Cottrell, T. E., S4.13

Cotty, P. J., S4.58, S4.89

Coutinho, T., S4.29, S4.109

Coutinho, T. A., S4.109

Cover crops

effects of on tomato diseases and nematodes, S4.36

for Fusarium oxysporum f. sp. niveum on watermelon, S3.3

increased pepper yields and, S4.49

organic tomato farming, impacts on rhizosphere pathogens in, S4.115

Pratylenchus penetrans and Verticillium dahliae on potato and, 519

for Rhizoctonia solani on rice, S4.144

for suppression of soybean diseases, S4.134
Vicia villosa, for management of Fusarium oxysporum $\mathrm{f}$. sp. niveum on watermelon, $\mathrm{S} 4.53$

Cowan, G., S4.120

Cowan, J., S6.11

Cowger, C., 498

Cowles, K., S4.50

Cowpea mosaic virus (CPMV), isolation of movement tubules and identification of host proteins involved in the viral movement from cell to cell, S4.44

Cox, K. D., S1.3, S4.26, S4.42, S4.128

Coy, E., S4.112

CPMV. See Cowpea mosaic virus

CPO, Phoma medicaginis on alfalfa, hyaline pycnidia formation and, $\mathrm{S} 4.24$

CPV. See Citrus psorosis virus

Cranberry. See Vaccinium spp.

Crane, J. M., S4.26

Craven, K., S4.117

Craven, K. D., S4.160

Crawford, J., S2.6

Creeping bentgrass. See Agrostis stolonifera

Crematogaster ants, for control of leaf miner and nettle caterpillar on oil palm, S4.87

Cromwell, W. A., S6.1

Cronartium ribicola, on white pine, proteomic study of interaction, S6.10

Cronn, R., S4.102

Crook, A. D., 498

Crop rotation, for suppression of Fusarium virguliforme on soybean, $\mathrm{S} 4.1$

CROPGRO: Soybean model, calibration and validation of, S4.101

Cropping sequence, impact on diseases, nematodes, and yield of peanut, cotton, and corn, S4.49

Crosby, M., S2.6

Crosslin, J., S4.164

Crouch, J., S1.1, S2.10, S4.26

Crous, P. W., S4.125, S4.138, S4.162, S4.167

CRT1 gene, plant immunity to Phytophthora infestans and, S4.75

Crucifers, Xanthomonas campestris pv. campestris on, evaluating control in greenhouse transplant production, S4.66

Crutcher, F. K., S6.3

Cruz, C. C., S5.3

Cruz, C. D., S4.27

Cruz, L., S4.36

Cruz, L. F., S4.27

Cruz Varona, A., S4.27

Cryphonectria hypovirus 1 , virulence and vegetative incompatibility in populations of chestnut blight fungus, 1161

Cryphonectria parasitica

on chestnut, in Lebanon, S4.104

Cryphonectria hypovirus 1 virulence and vegetative incompatibility in populations of, 116 invasion genetics of in Switzerland, 73 Lysobacter enzymogenes for control of, type IV pilus and, S4.90

Cryptococcus flavescens, for control of Fusarium

head blight on wheat, qPCR assay to track spread of, S5.8

CTLaV. See Cherry twisted leaf associated virus

(CTLaV)

CTV. See Citrus tristeza virus

Cubeta, M. A., S4.17

Cucumber. See Cucumis sativus

Cucumber, stuffing. See Cyclanthera pedata

Cucumber mosaic virus (CMV) in banana and plantain, in Central Africa, S4.87 GFP-tagged, in Nicotiana benthamii following transmission by aphid vector, $\mathrm{S} 4.65$ in passion fruit, in Korea, S4.63

Cucumis spp.

C. melo (cantaloupe), Salmonella spp. on, Erwinia tracheiphila and, S4.44

C. melo (melon), Cucurbit yellow stunting disorder virus (CYSDV) in, enhanced resistance and identification of reservoir hosts, S4.136 
C. melo (muskmelon), Podosphaera xanthii on,

resistant cultivars, $\mathrm{S} 1.6$

C. sativus (cucumber)

integrated approach to downy mildew management, S4.10

organic: Pseudoperonospora cubensis on, S1.5; Pythium ultimum and Rhizoctonia solani on, S3.4

Podosphaera xanthii on, suppression by UV-B, S4.116

Pseudoperonospora cubensis on, aerial concentration and escape of sporangia, disease severity and, S4.86

Pythium ultimum on: natural products for suppression of, S4.100; piperidine alkaloids from fire and, S4.68

root-knot nematodes on, optimizing use of MCW-2 for control of, S4.135

Cucurbit yellow stunting disorder virus (CYSDV), in melon, enhanced resistance and identification of reservoir hosts, S4.136

Cucurbita pepo (squash, zucchini)

Phytophthora capsici on, Bacillus subtilis IN937b

and host plant defense induction, S4.81

Pseudomonas syringae on, $\mathrm{S} 4.103$

Xanthomonas cucurbitae on, in midwest, S4.8

Zucchini lethal chlorosis virus in, insecticide application and secondary dissemination, S4.26

Cucurbits

grafting in, pros and cons of, S4.153

Pseudoperonospora cubensis on, sporangia

dynamics, population structure, and fungicide

efficacy, S5.4

Squash vein yellowing virus in, latent class analysis to estimate sensitivities and specificities of diagnostic tests for, $\mathrm{S} 4.122$

Culbreath, A., S2.7, S4.71, S4.113

Culbreath, A. Culbreath, A., S2.3

Culbreath, A. K., S2.2, S2.4, S2.8, S4.151

Cumagun, C. R., S4.27

Cunniffe, N. J., 365

Curland, R. D., S4.75

Curry, K. J., S2.8

Curtoviruses, reporter gene-transactivation system to study early events in infection process, S4.22

Cusicanqui, J., S4.45

Custódio, A. P., S4.27

CVd-III. See Citrus viroid III

Cyclanthera pedata (cucumber), begomovirus on, in Brazil, S4.71

Cyclic di-GMP, virulence of enteric plant pathogens and, S4.147

Cymoxanil, for Xanthomonas spp. on tomato and

pepper, $\mathrm{S} 2.3$

Cynodon dactylon (Bermudagrass) ectotrophic fungi isolated from roots of, S4.128 Ophiosphaerella korrae on, S4.39

CYP51 promoter insertions, Monilinia fructicola

fungicide sensitivity and, $\mathrm{S} 4.68$

CYP51A1, myclobutanil- and difenoconazole-resis-

tant Venturia inaequalis strains and, S4.128

CYP51B gene, Sclerotinia homoeocarpa propicona-

zole resistance and, $\mathrm{S} 4.56$

CYP83B1, transcript profiling during Alternaria spp. infection in cauliflower, $\mathrm{S} 4.108$

Cyst nematodes, effector proteins of, S4.166

Cytochrome $b$ gene, from Botrytis cinerea on apple,

structural diversity of, 315

CYVCV. See Citrus yellow vein clearing virus

Czymmek, K. J., S4.55

da Graça, J. V., S4.66

Da Silva, W. L., S2.2

da Silva, W. L., S4.28

Daane, K. M., S6.13

Daayf, F., S4.62

Dabade, S., S6.13

DADS. See Diallyl disulfide

Dagger nematode. See Xiphinema index
daGraca, J., S4.110

Dahlia spp., genetic diversity among endogenous plant pararetroviral sequences from geographically diverse sources of, $\mathrm{S} 4.3$

Dai, L., 779

Dally, E., S4.29

Dally, E. L., S3.2

Damann, K. E., S4.28

DaMatta, F. M., 892

Damicone, J. P., S4.28

Dandurand, L., S4.137

Dandurand, L. C., S4.64

Dang, H., S5.5

D'Angelo, D., S4.28

Daniels, J., S4.6, S4.155

Danies, G., S4.28, S4.84, S4.110

Dankers, H., S4.114

Danyluk, M. D., S4.126

2,4-DAPG. See 2,4-Diacetylphloroglucinol

Date palm. See Phoenix dactylifera

D'Attilio, D., S4.28

Daub, M. E., S4.11, S4.53, S4.86

Dauca carota (carrot)

Pythium spp. on, multigene analysis of species, in California and Michigan, S4.102

Rhizoctonia solani on, evaluation of seed treatments for, S5.1

Daugherty, M., S4.47

Daughtrey, M., S1.2, S1.4, S4.43

Davis, D. D., S4.8, S4.62

Davis, E., S4.111

Davis, E. L., S4.107

Davis, J. A., S2.11, S4.138

Davis, J. K., S4.106

Davis, R., S4.48

DAVIS, R. E., S3.2

Davis, R. E., S4.8, S4.29, S4.143

Davis, R. M., S4.38, S4.74, S4.160

Day, B., S4.45

Daylily. See Hemerocallis spp.

de Almeida Engler, J., 990

De Boer, S. H., 937

De Cock, A. M., S1.5

de Cock, A. W. A. M., 348

De La Fuente, L., S2.10, S4.27, S4.36, S4.85, S4.88,

S4.90, S4.157

De La Torre, C. M., 1176

de los Reyes, B. G., S4.20

de Maayer, P., S4.29

de Oliveira, R., 974

De Stradis, A., 1168

De Wolf, E., S5.2

Dean, R., S4.104

Dean, R. A., S4.41, S4.87

Debona, D., 1121

DeBuse, C., S4.39

Decision-making

fluid data and, S4.163

in regulatory plant pathology, $\mathrm{S} 4.163$

Dee, M. M., S4.36

Deep, S., S4.108

Dees, R., 1153

Dehesh, K., S4.100

Del Rio, L., S5.1

del Rio-Mendoza, L., S4.4

del Rio-Mendoza, L. E., S4.23

Demangeat, G., 627

Demers, J., S4.29

Demethylation inhibitor fungicides

for Cercospora beticola on sugar beet, CbCyp 51 gene and, 298, S4.12

for Cercospora kikuchii on soybean, application timing and rates of application of demethylation and, S4.107

for Monilinia fructicola

CYP51 promoter insertions and, S4.68

new resistance mechanism, $\mathrm{S} 2.2$

for Mycosphaerella graminicola, molecular mechanisms for decline in sensitivity to, S4.41 resistance and cross-resistance in Venturia inaequalis, 272

Sclerotinia homoeocarpa and, overexpression of ShCYP51B and ShatrD in resistant strains and, S4.56

Demoz, B., S4.38

den Holander, P. W., S4.44

Deng, J., S4.142

Deng, P., S2.7, S4.139

Deng, X., 779, S4.74

Dennis, G., S4.108

Deom, C. M., S4.101

Deora, A., S4.29

Deoxynivalenol (DON)

Fusarium graminearum on wheat and associations between the timing of fungicide application and percent control, S4.28 within-field variation in isolates, 128 influence of variable moisture patterns on, S4.5

in primary spikes and tillers of barley and wheat, S4.44

in wheat

cost-benefit assessment of integrated management strategies for, S5.8

integrating grain harvesting and preharvest management strategies to minimize losses due to, $\mathrm{S} 4.105$

wheat and barley candidate genes for host resistance to, S4.146

Deregulation of biotech crops

current processes involved in, S4.152

historical perspective of, S4.151

Derksen, R. D., S4.144

Descurainia sophia (flixweed), inhibitory effect of

volatiles of on soilborne pathogens of chili pepper, S6.12

Dew removal, Sclerotinia homoeocarpa on turfgrasses, fungicide efficacy and, S4.56

Dewdney, M., S4.53

Dewdney, M. M., S4.82, S4.127, S4.131

Dey, K., S1.6, S4.131

Dhiman, C., S6.11

Dhulipala, M. R., S4.24

Di, D., S4.80, S5.7

Di Bello, P. L., S3.2

2,4-Diacetylphloroglucinol

from Pseudomonas fluorescens, and induced systemic resistance in Arabidopsis thaliana against Xanthomonas translucens pv. undulosa, 390

from Pseudomonas sp. LBUM300, control of

Clavibacter michiganensis subsp.

michiganensis on tomato and, 967

Diallyl disulfide (DADS), for Sclerotium cepivorum on Allium spp., S4.39

Dianese, J. C., S4.105, S4.111

Diaphorina citri (Asian citrus psyllid)

Candidatus Liberibacter and comparative genomic analysis of interaction, S4.164

RNA sequence analysis, S4.64

cellular interactions and transcript profiling of Candidatus liberibacter asiaticus and solanacearum during psyllid infection and vectormediated transmission, S4.39

stylet morphometrics and ultrastructure in relation to feeding behavior of nymphs and adults of, S4.5

Diaporthe spp., on blueberry, in Chile, pathogenicity of, S4.34

Diatraea saccharalis, trypsin inhibitor from Inga laurina for control of, S4.97

Diaz, C. I., S4.43

Diaz, G. A., S4.29

Diaz-Arias, M. M., S4.30

Díaz-Pérez, J., S4.30

Dichlorofluorescein (DCFH), for estimation of reactive oxygen species, $\mathrm{S} 5.2$ 
Dickeya spp.

cyclic di-GMP, small RNAs, and quorum sensing in virulence of, S4.147

on potato, in Russia, S4.64

Dickstein, E. R., S4.19

Didymella bryoniae

microsatellite markers for assessing diversity of, S4.16

on watermelon, sensitivity of Florida isolates to boscalid, S4.52

Dietzgen, R., S4.121

Difenoconazole, for Venturia inaequalis, CYP51A1

overexpression and resistance, $\mathrm{S} 4.128$

Diffusible signal factor (DSF)

virulence of Xanthomonas oryzae pv. oryzicola on rice and, 841

Xylella fastidiosa on grape and, 1045

Dillard, H. R., S4.12

Dimock, M., S4.53

Ding, F., S4.30

Dinkeloo, K., S3.2, S3.4

Dipak, D., S4.30

Diplodia spp.

D. agrifolia, on coast live oak, S4.74

D. mutila, on pomegranate, $\mathrm{S} 4.83$

D. pinea, pine phenolics and systemically

induced resistance to, S5.9

D. seriata

on blueberry, S4.111

on pomegranate, $\mathrm{S} 4.83$

Direct repeat induced gene silencing (DRIGS), broad spectrum virus resistance and, S5.4

Disease resistance, against Sporisorium reiliana on

maize, $q H S 2.09$ locus and, 692

Disinfectants, for viruses, increasing efficacy and

effectiveness of, $\mathrm{S} 4.93$

Dita, M., S4.11

Dixon, R. A., S4.123

Djurle, A., 1006

DMI fungicides. See Demethylation inhibitor

fungicides

DMSO, herbivory of purple marsh crab on Spartina

alterniflora and, S4.34

DNA barcodes

for identification of rust populations on switchgrass, $\mathrm{S} 4.89$

reference biological collections and, S4.167

DNB. See Dothistroma needle blight

Dobhal, S., S4.30

Dobinson, K. F., S4.62

Dodine, resistance to in Venturia inaequalis, in

northeastern US populations after renewed use of

Syllit for apple scab management, S4.26

Dogwood. See Cornus spp.

Doll, D. A., S4.31

Dollet, M., S6.2

DON. See Deoxynivalenol

Donald, C., S4.72

Dong, W., S4.31

Dong, Z., S4.142

Donnua, S., S6.5

Donofrio, N., S3.4, S4.90

Donofrio, N. M., S3.2, S4.55

Donovan, S., S5.3

Doohan, F. M., S4.146

Doostdar, H., S6.2

Dorling, S., S4.16

Dornbusch, M., S4.105

Dorrance, A., S5.6, S5.9

Dorrance, A. E., S4.31, S5.5

dos Santos, P. C., S4.38

Dothistroma needle blight (DNB), 47

Dothistroma pini, on pine in France, 47

Doubledee, M. D., S2.3

Douce, K., S4.107

Doud, M. S., 567, S4.31

Douglas, S. M., S4.29

Douglas fir. See Pseudotsuga sp.

Dowd, P. F., S4.157
Dracaena spp., integrated measures as pest risk

management strategy for, S4.76

Drake, D. R., S4.57

Drake, K. A., S4.92

Draper, M., S6.13

Draper, M. A., S4.54

Drenth, A., S4.51

DRIGS. See Direct repeat induced gene silencing (DRIGS)

Driver, J., S4.72

Driver, J. G., S3.2, S4.31, S4.57

Dror, O., 23

Drought

herbivory of purple marsh crab on Spartina alterniflora and, S4.34

Puccinia striiformis on wheat, boosted regression trees to evaluate impacts of, S4.47

Druffel, K., S6.8

Druffel, K. L., S4.3

Dry, I. B., 65

DSF. See Diffusible signal factor

DsynD

for comparative genome analysis of members of the Magnaporthaceae, S4.104

for identification of syntenic regions between multiple genomes, S4.104

Du Toit, L. J., S6.8

du Toit, L. J., S4.38, S4.43, S4.125

Duan, Y., 567, S4.30, S4.31, S4.50, S4.63, S4.71,

S4.143, S4.144

Duarte, H. S., S4.32

Dubovoy, V., S4.57

Duerkop, B. A., 195

Dufault, N. S., S2.11

Dufualt, N. S., S4.114

Dugan, F., S4.125, S4.162

Dugyala, S., S5.4

Dull, A., S4.78

Dumenyo, K., S4.32

Dung, J. K., S4.32, S6.8, S6.9

Dunlap, C., S4.32

Dunn, A. R., S4.32, S4.115

Dunnell, K. L., S4.33

Đuragin, N. B., S4.115

Duressa, D., 443

Dutta, B., 461, S4.33

Dutta, M., S4.33

Dykema, N., S4.33

Dzhalilov, F., S4.64

Dzido, J., S6.2

Eaglewood, Chinese. See Aquilaria agallocha

Eastburn, D. M., S4.134

Eastwell, K. C., S4.2, S4.79, S4.128, S4.154

Ebel, R. C., S4.66

Eckhardt, L. G., S2.1, S2.8, S2.9, S2.11

Edema, M., S4.155

Edge effects, huanglongbing disease intensity and, S4.73

EDNA. See E-probe Diagnostic nucleic acids analysis

Edson, J., S1.2

Edwards, M. C., 539, S4.33, S4.72

Edwards, S. G., S4.98

Effector proteins

of cyst nematodes, S4.166

Magnaporthe oryzae on rice and, S4.165

Phytophthora infestans on potato and, S4.22

as probes to understand molecular mechanisms underlying plant-bacterial interactions and as markers for detecting bacterial diseases, S4.158

Effector-triggered immunity (ETI)

Pyrenophora teres f. teres on barley and, QTL mapping for, $\mathrm{S} 4.72$

VEGEVADERS game and, S4.2

Egel, D. S., S4.8

Egg yolk, for control of Sphaerotheca fusca on

watermelon, S4.61

Eggers, J. E., S4.32

Eggertson, Q. A., S1.5, S4.34
Eggplant. See Solanum melongena

Eichenlaub, R., 23

Eicosapentaenoic acid (EPA), in Arabidopsis and tomato, S4.100

Eicosapolyenoic acids (EP), in Arabidopsis and tomato, S4.100

Eid, S., S4.93

Eid, S. G., S4.3

Eisenmann, K., S1.2

Ejections, lagrangian stochastic models of spore trajectories within plant canopy turbulence and, 1026 Ekengren, S., 878

El Niño-Southern Oscillation, variability in Fusarium head blight epidemics and, 55

Elaeis guineensis (oil palm) leaf miner and nettle caterpillar on, S4.87 microorganisms associated with spear rot disease in, in Peru, S4.118

Electron microscopy, for characterization of biofumigated Ralstonia solanacearum cells, 105

Electronic nose technology, for detection of pesticide residues, $\mathrm{S} 4.136$

Elfar Aedo, K., S4.34

Elfekih, S., 456

Ellis, D., S4.167

Ellis, M. L., S4.31

Elmer, W., S1.2

Elmer, W. H., S1.3, S4.34

Elphinstone, J., S4.97

Elsinoë spp., on citrus

E. australis, in Texas, S4.110

E. fawcettii, fungicide application for control of sporulation, S4.82

Elymus spp., fungal endophytes in, $\mathrm{S} 4.21$

Emaraviruses, as mite viruses, S2.7

Emche, S. E., S3.4, S4.100

Enciso, J., S4.117

$\beta$-1,4-Endoglucanase, diet change in the foliar nematode Aphelenchoides fragariae and, 804

Endophytic bacteria, associated with butternut,

Japanese walnut, and hybrid butternut, inhibition of Ophiognomonia clavigignenti-juglandacearum by, S4.57

Endoribonuclease, plasmid-encoded PemK toxin of Xylella fastidiosa as, 32

Endornaviruses, in bean germplasm, S4.126

Enebak, S. A., S2.1

Eng, H., S4.53

Engler, G., 990

Enis, J. N., S4.24

Environmental Protection Agency (EPA), reviewing biopesticides in, $\mathrm{S} 4.154$

Environmental stress, modulation of plant resistance to viral pathogens by, S4.81

Ephelis spp., on perennial grasses, S4.14

E-probe Diagnostic Nucleic acids Analysis (EDNA) eliminating excessive sequence processing and, S4.155

for Phakopsora pachyrhizi from metagenomic samples, S4.35

for Plum pox virus, $\mathrm{S} 4.115$

for Pythium ultimum from metagenomic samples, S4.35

validation of, $\mathrm{S} 4.114$

epv gene, virulence of Xanthomonas oryzae pv.

oryzicola on rice and, 841

Er, H., S4.35

Erbs, G., S4.35, S4.116

Eremochloa ophiuroides (centipedegrass), Colletotrichum eremochloae on, S2.10

Ernest, E. G., S4.36

Ernst, S. C., S4.144

Erper, I., S3.1

Erwinia spp.

E. amylovora

amylovoran production by, orphan gene amyR as negative regulator of, $\mathrm{S} 4.131$ on apple: acyl carrier protein and virulence, S4.67; in Illinois, streptomycin-resistant, S4.60 
cyclic di-GMP, small RNAs, and quorum sensing in virulence of, S4.147 dynamics and environmental regulation of virulence gene expression in, $\mathrm{S} 4.5$

HrpL regulon and novel virulence factors in, S5.7

on pear, acyl carrier protein and virulence, S4.67

phytochelatin synthase and gamma-glutamyl peptidase for virulence of, S4.79

regulation of effector protein translocation by type iii secretion chaperones and $\mathrm{HrpN}$ in, S4.19

role of sigma factors in regulating virulence gene expression in, $\mathrm{S} 4.70$

small RNA chaperone Hfq and Hfq-regulated small RNAs RyhA and RprA and virulence of, S4.142

type III secretion system of, inhibitors and inducers of, S4.63

E. tracheiphila, Salmonella spp. on cantaloupe and, S4.44

Erysiphe necator

attack by phylogenetically diverse Ampelomyces strains in the field, 707

effects of prior vegetative growth, inoculum

density, light, and mating on conidiation of, 65 on grape

adaptation to heat stress in, S4.24

addressing uncertainty in epidemiology, S4.25

development and control under different levels of ascosporic inoculum dose, $\mathrm{S} 4.83$

effects on sunlight exposure on, 857

linkage disequilibrium and spatial aggregation of genotypes in sexually reproducing populations of, 997 modeling uncertainty in, S6.8

race-specific host resistance in North America, 83

sanitation and disease modeling for, $\mathrm{S} 4.68$

VitisGenPM for phenotyping of, S4.18

sentinel vines for monitoring fungicide resistance in, S3.1

Erythrina crista-galli (ceibo), Colletotrichum gloeosporioides on, $\mathrm{S} 4.91$

Escobar, C., S5.4

Eskalen, A., S4.35, S4.123

Eskandari, F. M., S3.2, S4.16

Esker, P., S5.7, S5.8

Esker, P. D., S4.21, S4.102, S4.135, S4.162, S6.6

Eskridge, K., S5.2

Esmenjaud, D., 627

Espindola, A. S., S4.35, S4.155

Esquivel, J. F., S4.79

Essential oils, for control of Botrytis cinerea and

Penicillium expansum on apple, S4.112

Estévez, C. E., S6.5

Estevez De Jensen, C., S6.4

Ethaboxam, for Phytophthora spp. and Pythium spp. amended agar and greenhouse assays for, S4.31 efficacy of, S4.31

Ethredge, R., S2.6

Ethylene, Botrytis cinerea on apple, endogenous resistance and, 135

Ethylene inhibitors, influence on plant physiology,

biomass, and yield, S4.152

ETI. See Effector-triggered immunity

Eujayl, I. A., S4.115

Euphorbia mosaic virus Yucatan Peninsula (EuMVYP), in Nicotiana benthamiana, virus-induced gene silencing and, $\mathrm{S} 4.83$

European hazelnut. See Corylus avellana

European water weed. See Trapa natans

Euwallacea fornicatus (Asian ambrosia beetle),

Fusarium sp. on avocado in California and, S4.35

Evans, E., S4.94

Evans, M. R., S4.36

Evans, R. G., S4.67

Evans, T. A., S4.36
Eveleigh, D., S4.105

Everhart, S. E., S4.36

Eversole, K., S4.166

Everts, K., S4.53

Everts, K. L., 652, S3.3, S4.115

Exserohilum turcicum

baseline sensitivity to pyraclostrobin, S4.21 on corn

effects of hybrid and foliar fungicide on disease severity and yield, S5.7

field evaluation of foliar fungicides for control of, S4.133

Extension plant pathology programs, recommendations for strengthening of, 652

Extracellular polysaccharide (EPS), Xanthomonas citri subsp. citri haloacid dehalogenase family phosphatase and, S4.69

Fabre, B., 47

Fageria, M., S4.149

Fagus grandifolia (American beech), Fusarium spp. on, in central Appalachians, S3.4

Fairchild, K. L., S4.36

Fajolu, O. L., S2.3, S4.36

Fakhoury, A. M., S4.11, S4.57, S4.84, S4.112

Falconi, C. E., S4.37

Fallopia japonica (Japanese knotweed), Pilidium concavum on, S4.16

Fallow periods, fungal and bacterial community responses to in Bolivian highlands, $\mathrm{S} 4.45$

Famoxadone, for Xanthomonas spp. on tomato and pepper, $\mathrm{S} 2.3$

Fan, J., 252, 841

Fang, W. H., S4.37

Faria, J. C., S4.37

Faris, J. D., 94, S4.33, S4.72, S4.73, S4.108

Farman, M. L., S5.3

Farnham, M., S4.133

Fauquet, C. M., S4.49, S4.155

Fayette, J., S2.3

FBV-1. See Fig badnavirus-1

Federal Bureau of Investigation (FBI), attacks on

U.S. food or agriculture and, S4.163

Fei, Z., S4.70

Feldman, T. S., 166

Felix, F., S2.5

Felix, R., S4.37

Feng, C., S4.26, S4.37, S4.38

Feng, J.-X., 948

Feng, S., S2.3, S4.71

Feng, X., S4.93, S6.9

Fenhexamid, for Botrytis cinerea on strawberry, resistance to, $\mathrm{S} 4.47$

Fennimore, S. A., S4.31

Ferguson, G., S4.93, S5.10

Feria, T. P., S6.6

Fern, leatherleaf. See Rumohra adiantiformis

Fernandes, J. C., S4.101

Fernandez-Ortuno, D., S2.3, S2.7

Fernández-Ortuño, D., S4.38, S4.47, S4.68

Fernando, D., S4.38

Ferrandino, F. J., 728, S1.3, S4.38

Ferraudo, G. M., S4.38

Ferro, C. G., S4.38

Ferry, A., S4.38

Fertigation, of coffee, rust and brown eye spot and, S4.28

Fibrillin4 (FBN4), apple disease resistance and, S4.110

Fichtner, E. J., S4.39

Ficke, A., S4.42

Ficus carica (fig), Fig badnavirus-1 in, 1182

Fiedler, K., S3.2, S4.39

Fig. See Ficus carica

Fig badnavirus-1 (FBV-1), in fig, 1182

Figueira, A., S4.62

Figueira, A. R., S4.44, S4.97

Filgueira-Duarte, J. J., S4.39

Filion, M., 967

Finger, M., S4.30
Fiola, J. A., S3.2

Fir, balsam. See Abies balsamea

Fir, Douglas. See Pseudotsuga sp.

Fire, identification of potential pyrophilous fungus following, S4.78

Fischer, I. H., S4.25

Fischer, K., S4.155

Fischer, K. F., S4.49

Fisher, K., S4.92

Fisher, T., S4.164

Fisher, T. W., S4.39, S4.164

Fjellstrom, R., 700

Flagella, phylogenetics of, S4.101

Flanders, T., S2.6

Flax, Verticillium spp. on, diagnostic assay for, S4.12

Fleites, L. A., S4.39, S4.138

Fletcher, J., S4.5, S4.6, S4.20, S4.35, S4.44, S4.58,

$\mathrm{S} 4.114, \mathrm{~S} 4.155$

Flixweed. See Descurainia sophia

Flooding

for control of soilborne potato pathogens, S6.11

Phytophthora cinnamomi on rhododendron and, S4.65

Flores, F., S4.39

Flowering ginger. See Alpinia purpurata

Fludioxonil, fitness and competitiveness of Penicil-

lium $\mathrm{spp}$. isolates with reduced sensitivity to, S6.9

Fluegel, M., 23

Fluopyram

for Alternaria alternata and Botrytis cinerea, resistance to, $\mathrm{S} 4.84$

for Sclerotinia minor on peanut, $\mathrm{S} 2.11$

Fluorimetric probes, for estimation of reactive oxygen species, S5.2

Flutriafol, for Phymatotrichopsis omnivora on cotton, S4.57

Foley, M., S4.58

Fondio, L., 733

Fonseca, M. E., S4.105

Forcelini, B. B., S4.40, S4.46

Ford, R., S4.125

Forster, H., S4.2, S4.129, S6.9, S6.10

Förster, H., 528

Fortunato, A., S4.40

Fortunato, A. A., 957

Fossdal, C., S4.40

Foster-Hartnett, D., S4.105

Fountain, J., S4.40

Fountain, J. C., S2.4

Fourrier, C., 908

Fowler, G., S5.3

Fowler, G. A., S4.27

Fox, G. M., S1.5, S1.6

Fraaije, B., S4.19

Fraaije, B. A., S4.41

Fragaria $\times$ ananassa (strawberry)

anaerobic soil disinfestation for control of disease in, $\mathrm{S} 4.77$

black root rot disease complex on, fungicides and mustard meal for management of, S4.72

Botrytis spp. on

B. cinerea: characterization of isolates resistant to multiple fungicides, S4.38; detection and molecular characterization of fenhexamid resistance in, $\mathrm{S} 4.47$; recent epidemic in Florida, S4.4; resistance to multiple fungicides, S4.4

in southeast United States, S4.68

Colletotrichum acutatum on, effect of inoculum concentration on, S4.40

epidemiology and prediction tools of gray mold, anthracnose fruit rot, and powdery mildew on, S4.17

inoculation of leaves with Colletotrichum spp. detection of host resistance and, S2.8

Macrophomina phaseolina on, control of, S4.80

methyl bromide alternatives for, $\mathrm{S} 4.86$

Phytophthora cactorum on, cultivar resistance and chemical and cultural control, S4.107 
Podosphaera aphanis on

early-season cryptic development, S4.7

temperature as repressor of ascocarp

formation, $\mathrm{S} 4.7$

Verticillium dahliae on

assay for rapid detection and quantification in soil, 331

management with and without fumigation, S6.9

Fraisse, C. W., S4.101

France, R. A., S4.41, S4.81

Francis, D. M., S5.10

Francis, F., S2.4, S4.41

Franck, W., S4.41, S4.87

Franco-Lara, L., S4.41

Frank, K., S4.33, S4.45

Frankliniella spp. (thrips)

F. bispinosa (Florida flower thrips), Groundnut

ringspot virus and Tomato chlorotic spot virus in, reassortment and, S4.133

F. fusca (tobacco thrips), Groundnut ringspot

virus and Tomato chlorotic spot virus in,

reassortment and, $\mathrm{S} 4.133$

F. occidentalis (western flower thrips) acquisition and transmission of Tomato spotted wilt virus by, $\mathrm{S} 4.98$

Groundnut ringspot virus and Tomato chlorotic spot virus in, reassortment and, S4.133

Salmonella enterica transmission to crops and, S4.112

Tomato spotted wilt virus and feeding behavior of, S4.149

Tomato spotted wilt virus in tomato and, S4.19

F. williamsi (corn thrips), Maize chlorotic mottle virus in corn and, S4.18

Frantz, G., S4.133

Frare, G. F., S4.41

Fraxinus spp. (ash), fluorimetric probes dichloro-

fluorescein (DCFH) and Amplex Red in estimating

reactive oxygen species in, $\mathrm{S} 5.2$

Frederick, R., S4.68

Frederick, Z., S4.42

Frederick, Z. A., S1.3

Freeman, J., S4.78

Freier, J., S4.128

French, R., S4.42, S4.118

French-Monar, R. D., S4.108, S6.3, S6.6

Frenkel, O., 83, 997

Friesen, T. L., 94, 498, 539, S4.33, S4.72, S4.73, S4.108

Friskop, A., S4.42

Friso, G., S4.119

Frohning, J. R., S5.4

Fromme, D. D., S4.57

Frost, K., S4.148

Fruit flies. See Anastrepha spp

Fry, W. E., S4.28, S4.84, S4.110, S4.118

Fu, L. Y., 1064

$\mathrm{Fu}, \mathrm{Z} ., 804$

Fuchs, M., S4.46, S4.92, S4.154

Fugate, K. K., S4.136

Fujie, M., 244, 469

Fujiyoshi, P., S4.10

Fukuhara, T., S4.126

Fukumoto, T., 741

Fulcher, A., S4.144

Fulladolsa, A. C., S4.42

Fulmer, A., S2.6

Fulmer, A. M., S2.4

Fumonisins, Fusarium fujikuroi on rice in Philippines and, S4.27

Funderburk, J., S4.133

Funding, international cooperation in, S4.166

Fungal Genetics Stock Center, best practice guide-

lines for microbial germplasm repositories at, S4.167

Fungicides. See also Resistance; Specific fungicides

ABC transporter gene from Sclerotinia homoeocarpa and, S4.105

for Alternaria spp.
A. alternata: resistance to, $\mathrm{S} 4.84$; on tangerine, geographic and cultivar distribution of resistant isolates, $\mathrm{S} 4.127$

A. solani on potato: detection of resistance,

S4.36; evaluation of in Wisconsin, S4.44

automatic application to corn field, yield and net return on investment, $\mathrm{S} 4.3$

bacterial, new generation of based on Bacillus amyloliquefaciens strain D747, S4.53

for Bipolaris spp., alternative mechanisms of resistance in, $\mathrm{S} 4.120$

for black root rot disease complex on strawberry,

S4.72

for Botrytis cinerea

on apple, resistance to, 315

resistance to, $\mathrm{S} 4.84$

on strawberry: characterization and management of isolates resistant to multiple fungicides, S4.38; resistance to, S4.47; super-resistance in Florida, S4.4

for Cercospora spp.

C. apii on celery, $\mathrm{S} 4.97$

C. arachidicola on peanut, penthiopyrad and pyraclostrobin for, $\mathrm{S} 2.2$

C. beticola on sugar beet: CbCyp51 gene and, S4.12; characterization of resistance, S5.2

for $C$. sojina on soybean, characterization of sensitive and resistant isolates, $\mathrm{S} 4.143$

for Corynespora cassiicola on tomato, resistance

to, $\mathrm{S} 4.2$

for Didymella bryoniae on watermelon,

sensitivity of Florida isolates, S4.52

effect of dose rate on emergence of resistance,

$\mathrm{S} 4.54$

for Elsinö̈ fawcettii sporulation, S4.82

for Exserohilum turcicum

baseline sensitivity to, $\mathrm{S} 4.21$

on corn, $\mathrm{S} 4.133$

and fruit rot following simulated hail event, S4.134

for Fusarium spp.

$F$. graminearum on wheat, percent control and deoxynivalenol contamination, S4.28 on potato, resistant strains, S4.92

for Fusicladium effusum on pecan, ground application, S4.13

for Guignardia citricarpa on citrus, baseline sensitivity to strobilurin fungicides, S4.53

for management of avocado branch canker in

California, S4.123

for Monilinia fructicola

CYP51 promoter insertions and, $\mathrm{S} 4.68$

dual resistance, fungicide-mediated transposition of genetic elements and, S4.21

on peach, new resistance mechanism, S2.2

for Mycosphaerella graminicola, molecular me-

chanisms for decline in sensitivity to, S4.41

for peanut foliar and soilborne diseases, S2.1

for Penicillium spp.

P. expansum on apple, resistance to, $\mathrm{S} 4.18$

fitness and competitiveness isolates with reduced sensitivity, S6.9

for Peronospora belbahrii on basil, S1.3

for Phakopsora pachyrhizi on soybean, isolate

sensitivity and timing of application, S4.122

for Phymatotrichopsis omnivora on cotton, S4.57

for Phytophthora infestans

EST analysis for candidate genes involved in resistance to, $\mathrm{S} 4.20$

sensitivity of recent strains in U.S., S4.84

Pithomyces chartarum on Miscanthus $\times$

giganteus and, S4.2

plant health benefit on creeping bentgrass, S4.11

for Plasmopara viticola on grape, G143 mutation and resistance, $\mathrm{S} 4.23$

for Pyrenopeziza brassicae on oilseed rape, reduced sensitivity, $\mathrm{S} 4.19$

rainfastness of on grape leaves, S4.106

for Rhizoctonia solani on sugar beet, S4.16, S4.63, S5.6, S5.7 for Sclerotinia spp.

S. homoeocarpa: overexpression of ShCYP51B and ShatrD in resistant strains and, S4.56; on turfgrass, heterokaryon formation and nuclear disproportion and, S4.63

S. minor on peanut, $\mathrm{S} 2.11$

S. sclerotiorum, characterization of metconazole sensitivity in north central United States, S4.4

seed and in-furrow, for Rhizoctonia solani on sugar beet, $\mathrm{S} 4.16$

sentinel vines for monitoring Erysiphe necator resistance, $\mathrm{S} 3.1$

simulated rainfall to evaluate removal of,

S4.46

for Sphaerotheca fusca on watermelon, S4.61

for Stagonospora nodorum on wheat, application timing and, S4.135

for Stenocarpella maydis on corn, S5.8

on switchgrass, rust intensity, biomass yield and, S4.14

two high-risk, concurrent, alternating, and mixture use of as resistance management strategy, S4.53

for Uromyces appendiculatus on bean, broadspectrum resistance and, S4.90

use of in corn, $\mathrm{S} 4.152$

for Ustilaginoidea virens and Neovossia horrida on rice, $\mathrm{S} 4.144$

for Venturia inaequalis

CYP51A1 overexpression and resistance, S4.128

dodine resistance in northeastern US populations after renewed use of Syllit for apple scab management, S4.26 resistance to, 272

for Xanthomonas spp.

on pepper, $\mathrm{S} 2.3$

on tomato, S2.3, S4.129

Funnell-Harris, D. L., S4.157

Furutani, N., S4.23

Fusarium spp.

on American beech, in central Appalachians, S3.4

on avocado in California, Asian ambrosia beetle and, S4.35

on barley

candidate genes for host resistance to, S4.146 prevalence and impact in U.K., S4.98

comparative study of transcription regulation in, S4.48

genomics for species recognition in, S4.162

on legumes, evaluating seed treatments for control of, S4.52

phylogenetic analysis using DNA

microsequences, S4.39

on potato, fungicide-resistant, detection and management of, S4.92

recovery of with unmanned aerial vehicles, S3.4

shift in species dominance of in southern Idaho, S6.7

on soybean, in Iowa, frequency of isolation, aggressiveness, and impact on yield, S4.30

on wheat

candidate genes for host resistance to, S4.146 molecular identification of species and chemotypes, S4.134

Fusarium spp.

F. circinatum

grasses as host of, S4.116

on Monterey pine, induced resistance in seedlings, S4.116, S6.13

F. fujikuroi, on rice in Philippines, phylogenetic analysis, fumonisin production, and genetic variability of, S4.27

$F$. graminearum

Bacillus amyloliquefaciens for control of, S4.26 on barley, trichothecenes and, S4.146 functional characterization of the gene $\mathrm{GzOch} 1$ for mannosyltransferase in, S4.95 
host colonization and sporulation in, S4.147 mycotoxin biosynthesis and, S4.146 origins of individual lineages, clues from genome-wide SNPs, S4.120

perithecial development on the straws decomposed in different soils with different levels of temperature, S2.9, S4.115

on wheat: association analysis to detect regions of genome conferring resistance, S5.5; associations between the timing of fungicide application and percent control, S4.28; atmospheric patterns and, 55; characterizing heterogeneity of disease incidence in a spatial hierarchy, 867 ; within-field variation in aggressiveness and DON production, 128; influence of moisture pattern on deoxynivalenol contamination, S4.5; soil moisture and temperature and, S2.9, S4.115; trichothecenes and, S4.146; variation for resistance to kernel infection and toxin accumulation, 306

F. incarnatum- F. equiseti species complex, on

blueberry, in Argentina, S4.91

F. oxysporum

f. sp. canariensis, on palms, in California, S6.12

f. sp. cepae, molecular identification of two vegetative compatibility groups of, 204

f. sp. chrysanthemi, on chrysanthemum, comparison of cultivar sensitivity, S1.2

for control of pale cyst nematode, S4.137

f. sp. cubense, on banana: genome sequence of tropical race 4 strain II5, S4.11; silicon and resistance to, $957, \mathrm{~S} 4.40$

f. sp. lycopersici: detection of in soil, S4.56; Fusarium oxysporum, genetic relationships among subpopulations of competitive nonpathogenic strains, S4.132; genetic relationships among subpopulations of competitive nonpathogenic strains, S4.132; on tomato, effect of plant products on rhizosphere population of, S4.126; on tomato, impact of divergent land management practices on crop health, 597

f. sp. niveum: Citrullus lanatus var. citroides lines with resistance to, S4.133; foliar leachate of Vicia villosa and growth rate of, S3.3; grafting for management of, S4.153; Vicia villosa green manure and Streptomyces lydicus for management of, S4.53

f. sp. spinaciae, on spinach, effects of micronutrients and limestone application, S4.43 strain Fo162, induction of resistance against Meloidogyne incognita and, 260 on tomato: diversity of endophytic populations, S4.29; endophytic populations as host adapted, S4.29

volatile organic compounds from affecting growth and defense of Arabidopsis thaliana, S4.12

$F$. palustre, herbivory of purple marsh crab on Spartina alterniflora and, S1.3, S4.34

F. solani

for control of pale cyst nematode, S4.137 on sweet potato, infection prior to harvest, $\mathrm{S} 2.2$

$F$. verticillioides

on corn, genetic diversity of, S6.4

SDA1 and polyol pathway in, S6.1

$F$. virguliforme

disruption of Fvepl gene in, S4.57

on soybean: disease occurrence after adoption of Roundup Ready technology in North America, S4.140; growing conditions and phytotoxin production in, $\mathrm{S} 4.139$; histological and genomic studies of interaction, S4.96; improved detection by real-time qPCR, S4.131; long-term crop rotations for suppression of, S4.1; microsatellite markers for, S4.132; profiling communities in soil using next-generation sequencing, S4.112 watering and interaction with Heterodera glycines in roots, $\mathrm{S} 4.118$

on wheat

cost-benefit assessment of integrated management strategies for, S5.8

Cryptococcus flavescens for control of, S5.8

integrating grain harvesting and preharvest management strategies to minimize losses due to, S4.105

Fusicladium spp.

F. carpophilum

on nectarine, sporulation of, relative humidity and temperature and, 421

on peach, sporulation model, S1.4

F. effusum

on pecan: effect of height on disease severity, S4.13; ground application of fungicide for control of, S4.13

Fusicoccum sp., on cranberry, S4.19

Fvepl gene, disruption of in Fusarium virguliforme, S4.57

Gaba, V., S4.20

Gabler, F., 83

Gabriel, D., S4.39

Gabriel, D. W., S4.138

Gadkar, V. J., 967

Gadoury, D. M., 65, S4.7, S4.18, S4.42, S4.83,

S4.116

Gaffoor, I., S4.138

Galactomyces citriaurantii, distinguishing from Galac-

tomyces geotrichum, characterization of population structure and, 528

Gallego-Giraldo, L., S4.123

Gallipoli, L., 827

Galvez, L. C., S5.4

Galvino Costa, S. B., S4.44, S4.97

Galvino-Costa, S., S4.62

Game, V., S4.2

Gamma-glutamyl transpeptidase, Erwinia amylovora

virulence and, S4.79

Ganiger, M., S4.150

Ganiger, M. C., S2.4

Gantt, S., S4.105

Gao, L., S4.15, S4.42

Garcia, A., S4.50

Garcia De La Cruz, R., S6.9

Garcia-Morales, S., S4.110

Gardiner, S., S4.146

Gardner, C. A., S4.166

Garibaldi, A., S4.94, S4.112

Garlic. See Allium sativum

Garrett, K. A., S4.45, S4.46, S4.160, S4.161

Garrido, P. A., S4.43

Gartemann, K.-H., 23

Gartung, J., S4.16

Garzon, C., S4.155

Garzon, C. D., S4.35, S4.43, S4.89

Gaskins, V. L., S4.43, S4.92, S4.127

Gatch, E. W., S4.43

Gautam, D., S4.44

Gautam, P., S4.44

Gee, C. T., S4.23

Geiser, D. M., S4.162

Geisler, M., S4.84

Genetically modified crops, serological tests of, S4.51

Genger, R. K., S4.77

Genome plasticity, of Burkholderia glumae on rice, S2.4

Gent, D. H., S4.137

George, S., 794

Geosmithia spp. See also Thousand cankers disease evolution, diversity, and ecology of, S4.159

G. morbida, on black walnut comparison of two isolation methods for, S4.128

genetic diversity in southeastern U.S., S4.49
Geotrichum candidum, on tomato

effect of irrigation regimes on, S4.39

non-invasive inoculation method to evaluate postharvest disease management strategies, S3.2

Geraldino Duarte, P. d., S4.44

Geraldino Duarte, P. S., S4.44

Geranium sp., Pythium aphanidermatum and $P$.

ultimum on, Bradysia impatiens as vector of, 283

Germplasm collections. See also Specific collections best practices for curation, S4.167

informatics tools for management associated data, S4.166

Gevens, A. J., 652, S4.44, S4.45, S4.107, S4.133,

S5.3, S5.9

GfkV. See Grapevine fleck virus

GFLV. See Grapevine fanleaf virus

GFP, to determine effects of relative humidity on infection, fungal colonization, and conidiation of Magnaporthe oryzae on perennial ryegrass turf, S4.69

GH61 family, of pathogenic white-rot fungus, substrate-specific expression during growth on wood, S4.40

Ghimire, S., S4.117

Ghimire, S. R., S4.160

Ghosh, S., S4.59, S4.60, S4.90

Giachetto, P., S4.11

Giampetruzzi, A., 1168

Gibberella fujikuroi

high-depth genome coverage of unusual species complex isolate that is cross-fertile with multiple species, $\mathrm{S} 4.120$

on rice, non-thermal plasma seed treatment for control of, S6.1

Gibberellic acid, twister disease of onion and, S6.7

Gibson, D. M., S4.26

Giese, W., S3.1

Giesler, L., S4.102, S5.8

Gilbertson, R. L., S4.9, S4.19, S4.22, S4.79

Gill, B. S., S4.61

Gill, R. K., S2.4

Gillett, J. M., S4.106

Gilley, M. D., S2.5, S4.45

Gilligan, C. A., 365

Gillikin, J. W., S4.53

Ginger, flowering. See Alpinia purpurata

Giordano, P. R., S4.45

Gislerod, H. R., S4.116

Gitaitis, R. D., S2.5, S4.33

Gladiolus, Uromyces transversalis on, fungicides for management of, S4.125

Glassy-winged sharpshooter. See Homalodisca vitripennis

Glechoma hederacea (ground ivy), Sclerotinia isolate for control of, S4.96

Gliocephalotrichum spp., on rambutan G. bulbilium, persistence of, S6.6

scanning electron microscopic analysis of speciation in, S6.3

G. simplex, persistence of, S6.6

Gliotoxin, biological control by Trichoderma virens and, S6.3

Globalization, management of invasive pathogens at farm level and, 609

Globodera spp. (cyst nematodes)

G. pallida (pale cyst nematode)

assay for estimating viability of, 140

dispersal measurement using historical and spatial statistical analyses, 620 nematophagous fungi and bacteria for control of, S4.137

on potato, predictive model of eradicative and management strategies for, S4.64

G. rostochiensis (potato cyst nematode) assay for estimating viability of, 140 dispersal measurement using historical and spatial statistical analyses, 620

Glomus constrictum, Macrophomina phaseolina on green gram and, S4.85 
Glover, K. D., S4.61, S5.5

GLRaV. See Grapevine leafroll-associated viruses

Glycine max (soybean)

Cercospora spp. on

C. kikuchii on: application timing and rates of application of demethylation inhibitor fungicide for, S4.107; effects of variety, inoculum source, and environment, S4.99

C. sojina on, characterization of QoI fungicide-resistant and sensitive isolates, $\mathrm{S} 4.143$

cover crops for suppression of diseases on, S4.134

effects of planting environment and seed quality on field emergence, S4.25

Fusarium spp. on

in Iowa, frequency of isolation, aggressiveness, and impact on yield, S4.30

$F$. virguliforme: disease occurrence after adoption of Roundup Ready technology in North America, S4.140; disruption of Fvep1 gene in, S4.57; growing conditions and phytotoxin production in, S4.139; histological and genomic studies of interaction, S4.96; improved detection by real-time qPCR, S4.131; interaction with Heterodera glycines in roots and, S4.118; long-term crop rotations for suppression of, S4.1; microsatellite markers for, S4.132; profiling communities in soil using next-generation sequencing, $\mathrm{S} 4.112$

glyphosate application rate, soybean sudden death syndrome and, S4.86

Heterodera glycines on engineering plant defenses to broaden host resistance, $\mathrm{S} 4.75$

interaction with Rhizoctonia solani, S5.4

RNA interference-induced resistance in, S4.69

F. virguliforme in roots and, S4.118

identification and characterization of seedborne

fungi on, S4.91

Macrophomina phaseolina on, effect of environ-

ment and genotype on, S2.3

Meloidogyne incognita on, recombinant inbred

lines for resistance against, $\mathrm{S} 4.138$

modeling effect of rust on yield of, S4.101

Nested Association Mapping (NAM) population, screening for resistance to Phytophthora sojae,

Fusarium graminearum and Pythium irregulare in, S5.9

oomycete diversity in soil samples from asymp-

tomatic fields, S1.2

pathogen and pest resistance in select commercial cultivars from 1923-2007, S4.134

Phakopsora pachyrhizi on

effects of daily temperature highs on development of, 761

effects of dew-period temperature changes on initiation of infection, S4.13

epidemiology of, S2.11

evaluation of recombinant inbred line (RIL) derived sister lines for resistance to, S2.4

fungicide sensitivity and timing of application and, S4.122

multiplexed immunofluorescence method for identification and viability determination, 1143, S4.128

new resistance gene in PI 567102B, S4.68

proteomics study of host-fungus interaction, S4.150

Simplicillium lanosoniveum for control of, 749

solar radiation and infection severity, 794

temporal dynamics of, leaf area index and, S4.82

Phytophthora sojae on

combining isolates to screen for novel sources of resistance to, $\mathrm{S} 4.77$

evaluation of commercial cultivars for pathogen and pest resistance, $\mathrm{S} 4.21$ identification and comparison of quantitative trait loci conferring partial resistance to, S5.6 identification of QTL for partial resistance to, S4.1

increase in virulence and pathotype number in

Minnesota since 1984, S5.1

race-specific resistance Rps $3 \mathrm{a}$ and $R p s 8$ to, S5.5

posttranscriptional gene silencing of the gene encoding aldolase from soybean cyst nematode by transformed soybean roots, $\mathrm{S} 4.77$

Q-PCR for fungi causing diseases of, S4.51

Rhizoctonia solani on

in fields undergoing rotation with rice, S4.113 interaction with Heterodera glycines, S5.4 strain AG-1 IA, genetic variation and evolutionary adaptability of, $\mathrm{S} 4.38$

Sclerotinia sclerotiorium on, assessing biological control agents for, S5.4

soybean target spot in, assessment of damage in 2011/2012 in Brazil, S4.80

Soybean vein necrosis associated virus in, epidemiology of, S4.144

Soybean yellow shoot virus in, in Brazil, S4.44

strains of oomycete species associated with seedling disease in U.S., S4.102

survey of oomycete species associated with seedling disease in U.S., S5.8

Glycohydrolase family proteins, of Xanthomonas citri subsp. citri, regulation of in xylan utilization during pathogenesis, S4.108

Glycoside hydrolase, characterization of bacteria producing, in Thailand soils, S4.105

Glynn, J., S6.3

Glyphosate, application rate, soybean sudden death syndrome and, S4.86

Gobena, D., S2.5

Gochez, A. M., S4.45

Godoy, C. V., S4.80

Godsey, C. B., S4.28

Goeke, S., S4.25

Goenaga, R., S6.3, S6.6

Goeser, N., S4.45

Gokce, E., S4.41, S4.87

Goldberg, N. P., S4.114

Golden, B. R., S4.3

Goldman, G., S5.3

Golino, D. A., S4.6, S4.7

Gomez-Montano, L., S4.45, S4.46

Gomi, K., 741

Gonçalves, C., S4.13

Gonçalves, C. R., S4.82

Gonçalves, F. P., S4.40, S4.46

Gonzales, M. A., S4.45

González, A. M., 1086

Gonzalez-Franco, A., S4.46, S4.101

Gonzalez-Gamez, E., S4.46

Gonzalez-Jaen, M., S4.27

Goodin, M., S4.121

Goodwill, T. R., S4.50, S5.5

Gooseberry, cape. See Physalis peruviana

Gooseberry vein banding associated virus (GVBAV),

in Ribes spp., of National Clonal Germplasm

Repository, S4.100

Gorbet, D. W., S2.2

Gordon, T. R., S4.99, S4.116, S6.9, S6.13

Goss, E., S4.160

Gossen, B. D., S4.29, S4.46, S4.78, S4.108

Gossypium spp. (cotton)

atoxigenic Aspergillus flavus on, sporulation and field movement of, S6.2

Corynespora cassiicola on, in Alabama, S4.18 impact and management of foliar diseases in Georgia, S2.6

impact of cropping sequence on diseases, nematodes, and yield of in southwest Alabama, S4.49

nematodes on, nitrogen rate and Telone II treatment, $\mathrm{S} 2.5$
Phymatotrichopsis omnivora on, flutriafol for management of, S4.57

transmission of Pantoea agglomerans by Nezara viridula and, S4.79

Goswami, R. S., S4.23, S4.52, S4.93

Gottula, J., S4.46

Gottwald, T., S4.73

Gottwald, T. R., S4.13, S4.65, S4.161

Gould, A. B., S4.11

Government, process overview, S4.166

Govers, F., 348

Gowen, S. R., S4.126

Grabke, A., S4.38, S4.47, S4.68

Gradziel, T. M., S4.139

Grafting

as alternative to methyl bromide, S4.120

of cucurbits, pros and cons of, S4.153

of eggplant, to manage soilborne disease, S4.153

for management of Meloidogyne spp. M. arenaria on eggplant, S4.104

M. incognita, S4.153

on melon, S4.119

on tomato, $\mathrm{S} 4.78$

for management of Phytophthora spp. on almond and stone fruits, S4.106

for management of Ralstonia solanacearum on tomato, $\mathrm{S} 4.85$

for management of Verticillium dahliae race 2 on tomato, S4.57

for prunus replant disease, $\mathrm{S} 4.93$

for screening for compounds effective against huanglongbing in citrus, 567

of tomato, to manage soilborne pathogens, S4.153

virus movement within grafted watermelon plants, S4.133

of watermelon, for management of Fusarium oxysporum $\mathrm{f}$. sp. niveum, $\mathrm{S} 4.153$

Graham, J. H., 597, S4.13, S4.47, S4.59

Gram, green. See Vigna radiata

Granke, L., S4.47

Granke, L. L., S5.4

Grant, J., S4.128

Grape. See Vitis spp.

Grapefruit. See Citrus paradisi

Grapevine fanleaf virus (GFLV)

control by fallow plants, 627

large satellite RNAs associated with, S4.46

multiplex RT-PCR for identification of, S4.20

Grapevine fleck virus (GfkV), in Virginia, S3.3,

S4.60

Grapevine leafroll-associated viruses (GLRaV)

GLRaV-2, in Virginia, S3.3

GLRaV-3

analysis of subjectivities about disease management among Napa Valley growers and vinters, S4.7

statistical parameters of spatial patterns of spread for, S4.6

in Virginia, S3.3

in grape, grape mealybug ecology and, S6.13 statewide survey and management of its vector in Virginia, S4.60

transmission of by Phenacoccus aceris, 717

Grapevine yellows, multilocus molecular genetic

characterization of phytoplasmas affecting

commercial vineyard, S3.2

Grass-clover soil amendment, Pythium ultimum on sugar beet and, 413

Grasses. See also Specific grasses

high-throughput screening for understanding symbioses with endophytes of, S1.1

modified for biofuel production, increased virus susceptibility in, S4.157

Neotyphodium spp. on, hybridization and evolution of, S4.160

Gray, L., S4.137

Gray, M. E., S4.2, S4.157

Gray, S. M., S4.62, S4.148, S4.149 
Gray mold, on strawberry, evaluation of epidemiology and prediction tools of, S4.17

Graybosch, R. A., S4.134

Green gram. See Vigna radiata

Green manure

for apple replant disease, $\mathrm{S} 4.77$

for control of Rhizoctonia solani on rice, S6.2 effects of on tomato diseases and nematodes, $\mathrm{S} 4.36$

increased pepper yields and, S4.49

Pratylenchus penetrans and Verticillium dahliae on potato and, 519

Vicia villosa, for management of Fusarium

oxysporum $\mathrm{f}$. sp. niveum on watermelon, $\mathrm{S} 4.53$

Green peach aphid. See Myzus persicae

Greenberg, E. P., 195

Greenbriar. See Smilax rotundifolia

Gregory, N. F., S4.36

Greidinger, A. L., S1.2

Griffin, G., S3.3

Griffin, G. J., S4.159

GRIN-Global, overview of, S4.166

GroEL, from Buchnera sp. on Pentalonia nigronervosa, interaction with Banana bunchy top virus and, S4.132

Groenewald, J. Z., S4.138, S4.162

Grönberg, L., 429

Groom, T., S4.92

Gross, D., S4.126

Gross, D. C., 899, S6.4

Großkinsky, D. K., 662

Groth, D., S2.6

Groth, D. E., S2.6, S4.75

Groth-Helms, D. L., S4.47

Ground ivy. See Glechoma hederacea

Groundnut ringspot virus (GRSV), Tomato chlorotic spot virus and, thrips transmission of virus reassortment, S4.133

Grove, G. G., S4.72, S4.137

Grover, K., S6.12

Groves, R., S4.112, S4.148

Grower Assisted Inspection (GAIP) programs, inci-

dence of five common pests in nurseries participating in, S4.89

GRSV. See Groundnut ringspot virus

Gruber, B., S4.47

Gruber, B. R., 656

Grunwald, N., S4.76, S4.117

Grünwald, N. J., S4.43, S4.48

Gu, C. S., S4.69

Gu, G., S4.48, S4.126

$\mathrm{Gu}$, J., S4.144

$\mathrm{Gu}$, Y., S4.74

Guan, W., S4.48

Guava. See Psidium spp.

Gubler, W. D., S4.24, S4.25, S4.91, S6.8

Gubler-Thomas (GT) model, for Erysiphe necator on grape, S6.8

Gudmestad, N., S4.71

Gudmestad, N. C., S4.134

Guerra-Peraza, O., S4.83

Guerrero, C. E., S6.2

Gugino, B. K., 652, S1.1, S1.7, S4.29, S4.92

Guha, S. Roy, S4.110

Guignardia spp.

G. bidwellii, on grape, weather-based fungicide application advisor for, $\mathrm{S} 4.111$

G. citricarpa, on citrus

baseline sensitivity to strobilurin fungicides, S4.53

copper sensitivity of Florida isolates, S4.52

nutritional and environmental effects on

germination and appressorium formation, S4.131

postharvest symptom development and viability of conidia, S4.35

G. psidii, on guava, effect of temperature on colonization, S4.25

Gulino, M., S4.112
Gullino, M., S4.94

Gulya, T., S4.42, S4.51

Gulya, T. J., S4.12

Gunadi, A., S5.5

Gundersen, B., S6.11

Gunderson, B., S6.11

Guo, B., S2.3, S2.7, S4.71

Guo, J., S4.21

Guo, L., S4.48

Guo, X., S4.26

Guo, Y., 567, S4.143

Gurung, S., 390, S4.48, S4.109

Guttieri, M., 306

Gutting, H., S4.85

GVBD. See Gooseberry vein banding associated virus

Gwinn, K., S4.14, S4.36

Gwinn, K. D., S2.3

Gymnosporangium sabinae, on callery pear, S1.4

Gysophila, Pantoea agglomerans pv. gypsophilae on, polar auxin transport and gall formation, S4.20

Haag, P., S4.124

Haatje Jan Kema, G., S4.11

Hackett, W. P., S4.78

Hadziabdic, D., S4.49

Haefele, D., S4.156

Haegele, J. W., S4.152

Hafez, Y. M., 848

Hagan, A., S4.115

Hagan, A. K., S2.5, S4.14, S4.18, S4.49

Hahn, M. G., 461

Hail, fungicides for control of fruit rot following, S4.134

Halbert, S. E., S4.23, S4.63

Halbrendt, N. O., S4.49

Hall, B., S4.117, S4.160

Hall, D., S4.31

Hall, D. G., S4.5

Hall, T. J., S4.64

Hallen-Adams, H., S4.134

Halley, S., S4.44

Halloran, J. M., S4.67

Haloacid dehydrogenase family phosphatase, Xantho-

monas citri subsp. citri virulence and, S4.69

Halterman, D., S4.22

Ham, J., S2.2, S2.4, S2.5, S4.22, S4.41, S4.62, S4.148

Ham, J. H., S2.6, S2.8

Hamann, A., S4.137

Hambleton, S., S4.22

Hametner, C., S4.146

Hamilton, J., S1.5

Hamilton, J. P., S4.34, S4.113

Hamm, P. B., S4.32, S4.137

Hammes, G. G., S2.2

Hammond, J., S4.49, S4.58, S4.69, S4.85, S4.155

Hammond, R. W., S4.85

Han, C., S4.69

Handelsman, J., S4.159

Handiseni, M., S6.2

Hanna, J., S4.102

Hanna, J. W., S4.63

Hanna, L. T., S4.104

Hannukkala, A., 323

Hansen, J. M., 390

Hansen, Z., S4.49

Hanson, B., S4.31

Hanson, L. E., S4.50, S5.5

Hanson, S., S4.50

Hao, G., S4.50

Hao, J., S4.102, S5.4

Hao, L., S4.50

Hao, Z., 692

Haplaxius crudus, transmission of Texas Phoenix palm decline to Pritchardia pacifica by, S6.2

Haque, M., S4.114

Hari, Y., 222

Harmon, C., 652
Harmon, P., S4.55

Harmon, P. F., 506, S4.17

Harris, G., S2.6

Harteveld, D. O., S4.51

Hartman, G. L., 1143, S4.21, S4.51, S4.103, S4.122,

S4.128, S4.134, S4.139, S4.140

Hartung, J. S., S3.3, S4.103

Harveson, R., S4.42, S4.51

Hassan, M., 1182

Hassan, M. H., S2.1

Hassell, R. L., S4.119, S4.133, S4.153

Hassett, B. T., S6.2

Haudenshield, J. S., 1143, S4.51, S4.128, S4.134, S4.140

Hausbeck, M., S4.47

Hausbeck, M. K., S4.85, S5.4

Hay, F. S., S4.92

Hayes, R. J., 443

Haygood, R., S2.5

Hayslett, M. C., S4.51

Hazelnut. See Corylus avellana

He, M., 413

He, R., S4.164

He, Y.-Q., 948

He, Z., S4.51

HealthCheck ${ }^{\mathrm{TM}}$ Panel, for detection of viruses in grapevine, S4.82

Heat stress, adaptation to in Erysiphe necator on grape, $\mathrm{S} 4.24$

Heath, S. M., S4.4

Hed, B., S4.52

Heeb, S., 575

Hegde, N., S4.52

Hein, G. L., S4.134, S5.2

Heinemann, A., S4.101

Helder, J., 140, 1153

Helianthus spp. (sunflower)

Plasmopara halstedii in seeds of, optimized duplex real-time PCR assay for detection of, 908

Puccinia helianthi on, race diversity in northern Great Plains in 2011, S4.42

Sclerotinia spp. on, identifying resistant germplasm, S4.12

unknown virus-like disease of in Nebraska, S4.51

Heliothis virescens, trypsin inhibitor from Inga

laurina for control of, S4.97

Heller, G., S4.103

Helminthosporium solani, on potato, organically grown, S4.77

Hemerocallis spp. (daylily), Puccinia hemerocallidis on, cultivar resistance to, $\mathrm{S} 4.31$

Hemipteran nymphs, new method for studying stylets of and the salivary sheaths in host plants, S4.5

Hempfling, J. W., S1.3

Henderson, D. C., S4.49, S4.155

Henderson, L., S4.47

Hendricks, K., S4.35

Hendricks, K. E., S4.52

Henkes, M., S4.59

Henn, A., S4.3

Henninger, A. S., S4.152

Herai, R., S4.11

Herbicides. See also Specific herbicides application rate, soybean sudden death syndrome and, S4.86

for Monilinia vaccinii-corymbosi on blueberry, propiconazole resistance and, S4.119

Herman, M., S4.45

Hernandez, J., S4.60

Hernandez Nopsa, J., S4.52

Hernandez-Gonzalez, J., S6.5

Hernandez-Zepeda, C., S4.52

Herranz, M. C., 1108

Herrbach, E., 717

Herrero, S., S4.11, S4.53, S4.86

Hert, M. M., S6.9

Heterobasidion irregulare on conifers, seasonal variation in presence and abundance of inoculum, S4.111 
substrate-specific expression of the enigmatic

GH61 family of during growth on wood, S4.40

Heterodera glycines (soybean cyst nematode)

genes at Rhg1 locus impacting development,

S4.26

reproduction of accessions of core bean collec-

tion, $\mathrm{S} 4.93$

on soybean

engineering plant defenses to broaden host resistance, $\mathrm{S} 4.75$

interaction with Rhizoctonia solani, S5.4

RNA interference-induced resistance in, S4.69

watering and interaction with Fusarium

virguliorme in roots, $\mathrm{S} 4.118$

transmission and population frequency of viruses in, S4.11

Heuser Gale, W. L., S4.155

Hfq, Erwinia amylovora virulence and, S4.142

HGSV. See Hibiscus green spot virus

Hibiscus green spot virus (HGSV), in Citrus volk-

ameriana, 122

High plains virus (HPV), detection with loop-

mediated isothermal amplification, S4.6

Highland, H., S4.53

High-throughput assays, for detection of citrus patho-

gens, S4.131

High-throughput sequencing technology

for understanding grass-endophyte symbiosis,

S1.1

understanding of plant-pathogenic bacteria and, S4.148

Higrevirus, as new virus genus, 122

Hildebrand, P. D., S4.121

Hilf, M. E., S4.90

Hill, A., S5.2

Hill, M., S6.13

Hillman, B., S1.2, S1.4, S4.90, S4.93

Himmelstein, J., S3.3

Himmelstein, J. C., S4.53

Hincapie, M., S4.53

Hirsch, R. L., S2.6

$H m s F$, as virulence factor of Xanthomonas citri

subsp. citri, S4.130

Ho, T., S4.53

Hoang, N., S4.9

Hobbelen, P., S4.54

Hobbelen, P. H., S4.53

Hobbs, H. A., S4.21

Hodda, M., 620

Hodges, A. C., S4.54

Hoffman, M. T., S4.31

Hoffstetter, A. L., S5.5

Högberg, N., 323

Hogg, E. H., S4.137

Holbrook, C., S2.3, S2.4, S2.8

Holbrook, C. C., S2.2

Holland, J. B., 1016

Holland, R., S4.25

Holland, R. M., S4.54

Holland, R. T., S2.3

Hollier, C., S2.6, S4.75

Hollier, C. A., S4.3

Holmes, E. C., S1.7

Homa, K., S1.3

Homalodisca vitripennis (winged sharpshooter),

Xylella fastidiosa and, plant water stress and vector

feeding behavior, $\mathrm{S} 4.8$

Hong, C., S4.55, S4.140

Hong, J. C., 924

Hop. See Humulus lupulus

Hopkins, D., S4.55

Hopkins, D. L., S4.55

Hoplolaimus sp. (lance nematode), on corn, two

methods for extraction from roots, $\mathrm{S} 4.9$

Hordeum vulgare (barley)

Cochliobolus sativus on

sensitivity of 1050 accessions, S4.3

unique genomic region of pathotype 2 and virulence of, S4.68 deoxynivalenol and Fusarium diseases of, identification of candidate resistance genes, S4.146

deoxynivalenol concentration in primary spikes and tillers of, S4.44

Fusarium graminearum on, trichothecenes and,

S4.146

Magnaporthe oryzae on

MoHyrl and MoyAP1, reactive oxygen species and, S4.55

novel locus $R$ mo 2 conditioning resistance to host-specific subgroups, 674

marker-assisted breeding for disease resistance in, 560

prevalence and impact of Fusarium and

Microdochium species in U.K., S4.98

Puccinia striiformis on, in United States in 2011,

S4.130

Pyrenophora teres on

identification of multiple virulence QTL, S4.108

QTL mapping of effector-triggered sensitivity interaction, S4.72

in United States, S4.67

virulence profile and genetic structure of a

North Dakota population of, 539

Septoria passerinii on, identification of novel resistance loci, 683

Horizontal gene transfer

Alternaria arborescens on tomato and, S4.161, S5.5

bacterial crop pathogen emergence and, S4.160

Pseudomonas syringae on tomato and, S4.160

Horn, B. W., S4.1

Horner, D., S4.120

Horsetail. See Hyparrhenia rufa

Horvath, B. J., S4.11, S4.111

Host adaptation, of Fusarium oxysporum on tomato,

S4.29

Host gene silencing

influence of parasitic interactions on, S4.130

root-knot nematodes and, S5.9

Host resistance. See also Induced systemic resistance

against Agrobacterium tumefaciens, on walnut,

identification of sources of resistance in germplasm, $\mathrm{S} 4.78$

of alfalfa, isoflavenoid compounds and, S4.105

against Alternaria solani

in hybrids between a Solanum tuberosum

haploid and S. raphanifolium, 214

on potato, $\mathrm{S} 4.36$

against Amarillaria mellea, identification of tree-

crop rootstocks with, $\mathrm{S} 4.10$

of apple

against Botrytis cinerea, endogenous ethylene biosynthesis and, 135

plastoquinone partitioning in chloroplast and, S4.110

of Arabidopsis thaliana

against Hyaloperonospora arabidopsidis,

sublethal UV irradiation and, S4.81

against Xanthomonas translucens pv. undu-

losa, 2,4-diacetylphloroglucinol and, 390

against Aspergillus flavus, on corn

tissue-specific components of, 787

WRKY transcription factors and, S2.4

AvrPiz-t suppresses host innate immunity by

targeting the RING finger E3 ligases APIP6 and APIP10, S4.165

of banana, against Fusarium oxysporum f. sp.

cubense, silicon amendments and, 957, S4.40

of barley

against Magnaporthe oryzae, Rmo2 gene and, 674

against Septoria passerinii, identification of novel resistance loci, 683

of basil, against Peronospora belbahrii, peroxi-

dase, total phenolics, and host resistance, S4.79

of bean, against Xanthomonas campestris on,

image analysis and studies of, 434 of blueberry

against Colletotrichum acutatum, S4.150

against Xylella fastidiosa, xylem hydraulic

conductance and, S4.54

against Botrytis cinerea

on apple, endogenous ethylene biosynthesis and, 135

on wild tomato, S2.9

of Brassica spp., against Plasmodiophora

brassicae on, comparison of host resistance

and, S4.78

against Cercospora spp., S4.11

C. hydrangeae, on hydrangea, light density and, $\mathrm{S} 4.70$

against Cercosporidium personatum, on peanut, evaluation of recombinant inbred line (RIL) derived lines for, $\mathrm{S} 2.4$

of chile pepper, against Phytophthora capsici,

following inoculation with nonhost Phytoph

thora nicotianae, S4.114

of coast live oak, against Phytophthora ramorum, metabolite profiling to predict, S5.3

against Colletotrichum spp.

C. acutatum, on blueberry, $\mathrm{S} 4.150$

on strawberry, inoculation of leaves for detection of, S2.8

C. sublineolum, on sorghum, silicon supplements, leaf gas exchange and oxidative stress and, 892

of corn

against Aspergillus flavus: tissue-specific components of, 787; WRKY transcription factors and, S2.4

induced systemic resistance, $\mathrm{S} 4.92$ against Johnsongrass mosaic virus and Sorghum mosaic virus of, Wsm loci and, S4.114 against Maize rayado fino virus, S5.10

against Stenocarpella maydis, mapping genes associated with, S4.102

of daylily, against Puccinia hemerocallidis, S4.31 against deoxynivalenol and Fusarium diseases of

wheat and barley, identification of candidate

genes for, S4.146

against Diplodia pinea, phenolic compounds and, S5.9

against Erysiphe necator, on grape, 83

evaluating select pea varieties for, $\mathrm{S} 1.1$

against Fusarium spp.

F. circinatum, on Monterey pine, S4.116

$F$. graminearum: on wheat, association analysis to detect regions of genome conferring, S5.5; on wheat, variation in, 306

F. oxysporum f. sp. cubense, on banana, silicon amendments and, 957, S4.40

F. oxysporum f. sp. niveum, on watermelon, S4.133

of grape

against Erysiphe necator, 83

against Plasmopara viticola, mode of, 1094 against Heterodera glycines

on soybean: engineering of, S4.75; RNA interference-induced, S4.69

of hop, against Podosphaera macularis, S4.137 against huanglongbing, acidbenzolar-S-methyl

and, S4.47

against Hyaloperonospora arabidopsidis, on

Arabidopsis thaliana, sublethal UV irradiation and, S4.81

of hydrangea, against Cercospora hydrangeae,

light density and, S4.70

induced systemic resistance in maize, S4.92

induction of against Meloidogyne incognita, 260

induction of in wheat by Pseudomonas fluores-

cens, S6.10

isoflavenoid compounds and, in alfalfa, S4.105 against Johnsongrass mosaic virus and Sorghum mosaic virus, of corn, Wsm loci and, S4.114 against Leptographium spp., on pine, familial variation in, S2.9 
against Leptosphaeria maculans, on oilseed rape, hybridization for resistance transfer into, S4.136

of lima bean, against Phytophthora capsici, evaluation of germplasm for, S4.36

against Magnaporthe oryzae

on barley, Rmo2 gene and, 674

on rice: disease reactions of IRRI near-

isogenic rice to U.S. isolates, S4.37; identi-

fication of blast resistance genes, S4.130;

identification of $\mathrm{Pib}$ gene in National Small

Grains Collection and, 700; methods for

identifying and quantifying, S4.135; Pi2-1

and Pi51(t) genes and, 779; Pik- $h$ and,

S4.142

on ryegrass, silicon and, $\mathrm{S} 4.96$

against Maize rayado fino virus, in corn, S5.10

marker-assisted breeding for in wheat and barley,

minor gene-for-minor gene interaction

explaining, nonhypersensitive polygenic partial, 1086

of Monterey pine, against Fusarium circinatum,

S4.116

of muskmelon, against Podosphaera xanthii, S1.6 of oilseed rape

against Leptosphaeria maculans, hybridization for resistance transfer into, S4.136 against Pyrenopeziza brassicae, S4.19

of peanut

against Cercosporidium personatum, evaluation of recombinant inbred line (RIL)

derived lines for, S2.4

evaluation of ICRISAT peanut varieties for resistance to foliar diseases, $\mathrm{S} 2.4$

against Puccinia arachidis, S2.8, S4.151

against Sclerotinia minor, S2.11

against Tomato spotted wilt virus

identification of putative genes for, S2.3,

S4.37; improvements in, S2.2; interactions with thrips and, S4.113

of pepper, against Phytophthora capsici, correla-

tion with fruit traits, $\mathrm{S} 4.85$

against Peronospora spp.

$P$. belbahrii, on basil, peroxidase, total phenolics, and host resistance, S4.79

P. farinosa f. sp. spinaciae, on spinach, S4.26 against Phakopsora pachyrhizi, on soybean

evaluation of recombinant inbred line (RIL)

derived sister lines for, S2.4

new gene in PI 567102B, S4.68

against Phytophthora spp.

P. cactorum, on strawberry, S4.107

$P$. capsici: on chile pepper following inoculation with nonhost Phytophthora nicotianae, S4.114; on lima bean, evaluation of germplasm for, S4.36; on pepper, correlation with fruit traits, $\mathrm{S} 4.85$

$P$. infestans, CRT1 gene and, S4.75

$P$. ramorum, on coast live oak, metabolite profiling to predict, S5.3

P. sojae, on soybean: combining isolates to screen for novel sources of, S4.77; evaluation of commercial cultivars for, $\mathrm{S} 4.21$; identification and comparison of QTL for, S5.6; identification of QTL for, S4.1; racespecific resistance Rps3a and Rps8, S5.5

of pine, against Leptographium spp., familial

variation in, S2.9

against Plasmodiophora brassicae, on Brassica spp., S4.78

against Plasmopara viticola, on grape, mode of, 1094

against Podosphaera spp.

P. macularis, on hop, S4.137

P. xanthii, on muskmelon, S1.6

of potato

against Alternaria solani, S4.36

against Potato virus $Y$, breeding for, S4.148 against Pseudomonas syringae, on Arabidopsis thaliana, compartment-specific antioxidative defense, 662

against Puccinia spp.

$P$. arachidis, on peanut, $\mathrm{S} 2.8, \mathrm{~S} 4.151$

P. emaculata, on switchgrass, $\mathrm{S} 4.157$

P. hemerocallidis, on daylily, $\mathrm{S} 4.31$

$P$. kuehnii, on sugarcane, S4.13

P. striiformis f. sp tritici, on wheat,

temperature shifts and, S4.16

P. triticina, on wheat: Aegilops tauschii as a source of, S4.61; histological characteri-

zation of wheat pre-and post-haustorial resistance components, S5.4

against Pyrenopeziza brassicae, on oilseed rape, S4.19

against Ralstonia solanacearum

on tobacco, temperature and, S4.12

on tomato, transcriptomic and genetic analysis of, S4.151

of rice

AvrPiz-t suppresses host innate immunity by targeting the RING finger E3 ligases APIP6 and APIP10 in, S4.165

against Magnaporthe oryzae: disease reactions of IRRI near-isogenic rice to U.S. isolates, S4.37; identification of blast resistance genes, S4.130; identification of $P i b$ gene in National Small Grains Collection and, 700; methods for identifying and quantifying, S4.135; Pi2-1 and Pi51(t) genes and, 779; Pik- $h$ and, S4.142

against Xanthomonas oryzae pv. oryzae, Xa33 gene and, 222

of ryegrass, against Magnaporthe oryzae, silicon and, S4.96

against Sclerotinia minor, on peanut, S2.11

against Septoria passerinii, on barley, identifi-

cation of novel resistance loci, 683

of sorghum, against Colletotrichum sublineolum,

silicon supplements, leaf gas exchange and

oxidative stress and, 892

of soybean

against Heterodera glycines, RNA interference-induced, S4.69

against Phakopsora pachyrhizi: evaluation of recombinant inbred line (RIL) derived sister lines for, S2.4; new gene in PI 567102B, S4.68

against Phytophthora sojae: combining isolates to screen for novel sources of, S4.77; evaluation of commercial cultivars for, S4.21; identification and comparison of QTL for, S5.6; identification of QTL for, $\mathrm{S} 4.1$; race-specific resistance $R p s 3 \mathrm{a}$ and Rps8, S5.5

screening Nested Association Mapping (NAM) population for, S5.9

in select commercial cultivars from 1923 2007, S4.134

of spinach, against Peronospora farinosa f. sp spinaciae, $\mathrm{S} 4.26$

against Stenocarpella maydis, on corn, mapping genes associated with, S4.102

of strawberry against Colletotrichum spp., inoculation of leaves for detection of, $\mathrm{S} 2.8$ against Phytophthora cactorum, S4.107

of sugarcane, against Puccinia kuehnii, S4.13

of switchgrass, against Puccinia emaculata,

S4.157

of tobacco, against Ralstonia solanacearum, temperature and, S4.12

of tomato, against Ralstonia solanacearum, transcriptomic and genetic analysis of, S4.151

against Tomato spotted wilt virus, in peanut identification of putative genes for, S2.3, S4.37

improvements in, S2.2 interactions with thrips and, S4.113

to viral pathogens, modulation by abiotic stress, S4.81

of walnut, against Agrobacterium tumefaciens, identification of sources of resistance in germplasm, S4.78

of watermelon, against Fusarium oxysporum $\mathrm{f}$. sp. niveum race $2, \mathrm{~S} 4.133$

of wheat

against Fusarium graminearum: association analysis to detect regions of genome conferring, S5.5; variation in, 306

against Puccinia striiformis f. sp tritici, temperature shifts and, S4.16

against Puccinia triticina: Aegilops tauschii as a source of, S4.61; histological characterization of wheat pre-and post-haustorial resistance components, S5.4

of wild tomato, against Botrytis cinerea, S2.9

against Xanthomonas spp.

$X$. campestris, on bean, image analysis and studies of, 434

X. oryzae pv. oryzae, on rice, Xa33 gene and, 222

X. translucens pv. undulosa, on Arabidopsis thaliana, 2,4-diacetylphloroglucinol and, 390

against Xylella fastidiosa, on blueberry, xylem

hydraulic conductance and, S4.54

Hosta virus $X(\mathrm{HVX})$, biological and molecular

characterization of U.S. isolate, 1176

Host-selective toxins (HST). See also Necrotrophic

effectors, Alternaria alternata on rough lemon,

ACRTS1 gene and, 741

Hotchkiss, M. H., S4.13

Hoy, M. A., S4.19

Hoyt, P. R., S4.155

HPV. See High plains virus

HrpL regulon, in Erwinia amylovora, novel virulence factors and, S5.7

HrpN, in Erwinia amylovora, translocation of effector proteins and, S4.19

HrpS, Erwinia amylovora virulence and, S4.70

hshB gene, Xanthomonas oryzae pv. oryzicola virulence and, 252

HsplO4 gene, Magnaporthe oryzae pathogenicity and gene regulation and, S3.4

HST. See Host-selective toxins

$\mathrm{Hu}$, B., 252, 841

Hu, H., S4.55, S6.1, S6.3

Hu, J., S1.6, S4.99, S4.131, S5.5

$\mathrm{Hu}$, J. S., 122

$\mathrm{Hu}, \mathrm{X} ., \mathrm{S} 4.140$

$\mathrm{Hu}, \mathrm{Y} ., \mathrm{S} 4.55$

Hua, L., S4.142

Huamani, G., S4.118

Huang, C., S4.56, S4.139

Huang, G., S4.107

Huang, H., 779, S4.22

Huang, K., S3.2, S4.55

Huang, M., S4.116

Huang, Q., S3.2, S4.48

Huang, Y., S4.56

Huang, Y. F., 267

Huanglongbing. See also Specific causal agents early root infection and damage in disease development, S4.59

edge effects and disease intensity, S4.73 graft-based chemotherapy method for screening effective molecules and rescuing affected plants, 567

integration of soil-applied neonicotinoid insecticides and acibenzolar-Smethyl for systemic acquired resistance (SAR) control of, S4.47 modeling flush-to-flush transmission, effects of control strategies on disease dynamics and, S4.23

proficiency test results summary for NPPLAP detection assay, $\mathrm{S} 4.108$ 
real-time PCR quantification of live bacteria in citrus and noncitrus hosts of, S4.55

screening citrus and relatives for tolerance to, S4.63

in Texas, first report, $\mathrm{S} 4.66$

thermal treatments for suppression or elimination of, $\mathrm{S} 4.31$

Hudson, M., S4.26

Huerta, A. I., S4.56

Hughes, G., S4.163

Hughes, T. J., S5.9

Hulbert, S., S4.141

Hulbert, S. H., S4.8

Hulvey, J., S1.4, S4.56, S4.63, S4.105

Humann, J. L., S4.125

Humann, R., S4.42

Humidity

colonization of Clavibacter michiganensis subsp. michiganensis on tomato and, 177

Fusicladium carpophilum on nectarine and, 421

Hummel, A., S4.127

Humulus lupulus (hop), Podosphaera macularis on characterization of ontogenic resistance, S4.137 mating type distribution in Pacific Northwest, S4.137

Hunsberger, L. K., S1.5, S1.6

Hurburgh, C. R., S4.101

Hurd, H., S4.150

Hussey, R., S4.111

Hussey, R. S., S4.107

Hutchins, J. T., S6.13

Huyen, B., S4.122

HVX. See Hosta virus $X$

Hyaloperonospora spp.

H. arabidopsidis, on Arabidopsis thaliana, sublethal UV irradiation and host resistance, S4.81

H. camelinae, on Camelina sativa, in Washington state, $\mathrm{S} 4.8$

Hyatt, L., S1.2

Hybridization

and evolution of Neotyphodium spp. on grasses, S4.160

Phytophthora pathogens and, S4.160

Verticillium longisporum host range and, S4.160

Hydrangea macrophylla, Cercospora hydrangeae on, light density and host resistance, S4.70

Hydraulic conductance, resistance to Xylella fastidiosa on blueberry and, S4.54

Hydrogen cyanide, from Pseudomonas sp. LBUM300, control of Clavibacter michiganensis subsp. michiganensis on tomato and, 967

Hydrogen peroxide, up-regulation of antioxidants in tobacco by and suppression of necrotic disease symptoms, 848

Hydroponic culture, of cilantro, Pythium dissotocum and, S6.5

Hyon, G.-S., 674

Hyparrhenia rufa (Jaragua grass, horsetail), patho-

genic fungi for control of, S6.5

Hypersensitive response (HR)

Potato virus $Y$ strain from Syria inducing, S4.23

Tomato bushy stunt virus in Nicotiana spp. and, S4.5

Xanthomonas citri subsp. citri and Xanthomonas fuscans pv. aurantifolii, comparison between avrGf1 and avrGf2 which elicit hypersensitive reactions in, $\mathrm{S} 4.45$

Ichimura, K., 741

ICRISAT, evaluation of varieties for resistance to

foliar peanut diseases in Haiti, S2.4

Idris, A. M., S4.51, S4.56

Iftikhar, R., S4.65

Ignatov, A., S4.57, S4.64

lizuka, K., S4.141

Ilarviruses, of Prunus spp., 1108

ILT1. See Inga laurina trypsin inhibitor (ILT1)

Ilut, D., S4.162

Image analysis, Xanthomonas campestris on common bean, studies of quantitative disease resistance and, 434

Immunoassays

for detection of Citrus psorosis virus, S4.97

for Phakopsora pachyrhizi on soybean, 1143 , S4.128

Impatiens, Plasmopara obducens on, in Florida, S6.4

Imperata cylindrica (cogongrass), impact on root-

feeding bark beetle populations associated with

Southern Pine Decline, S2.1

Inácio, C. A., S4.111

Inclusion bodies, CHUP1 and Cauliflower mosaic virus, $\mathrm{S} 4.6$

Inderbitzin, P., S4.109, S4.160

Indicator plants, citrus certification programs and, S4.67

Induced systemic resistance (ISR)

in Arabidopsis thaliana against Xanthomonas translucens pv. undulosa, 2,4-diacetylphloroglucinol and, 390

of aspen to pathogens and wounding, S4.40

against Fusarium circinatum on Monterey pine, S4.116

in maize, $\mathrm{S} 4.92$

Infectious period, importance of, S4.38

Inga laurina trypsin inhibitor (ILT1), for control of

Diatraea saccharalis and Heliothis virescens, S4.97

Inglis, D. A., S6.11

Ingram, D., S4.3

Ingram, T. W., S2.6

Innate immunity

AvrPiz-t suppresses host innate immunity by targeting the RING finger E3 ligases APIP6 and APIP10 in rice, S4.165

peptidoglycan and activation of, $\mathrm{S} 4.35$

perception and signalling induced by a bacterial microbe-associated molecular pattern (MAMP) in plants, $\mathrm{S} 4.116$

Inoculum production, time scales of, dynamics of epidemic and, 728

Inonotus obliquus, on birch, peroxidase localization

in infected plant, S4.141

Inoue, K., S4.62

Inoue, Y., 674

Insecticides

for mealybugs on grape, S3.3

secondary dissemination of Zucchini lethal chlorosis virus and, S4.26

for Tomato spotted wilt virus in California, S4.122

Integrated pest management (IPM)

for cucumber downy mildew, S4.10

for tomato, farmer participatory approach and, S4.62

Interactome, predicted, for Zea mays, S4.84

Internal transcribed spacer. See ITS

Internet media, for disease detection and tracking, S4.161

Into, F., S6.3

Invasive species

Cryphonectria parasitica, invasion genetics of in Switzerland, 73

engaging researchers, county faculty, and K-12 teachers in education about, S4.54

Iodomethane, for control of Armillaria mellea on

cherry and peach, S6.10

Ioos, R., 47, 908

Iorizzo, M., S4.15

Iott, M., S4.57

Iott, M. C., S4.31

$i$ PhyClassifier II, for phytoplasma identification and classification, S4.143

IPI-O, Phytophthora infestans on potato and, S4.22 Ipomoea batatas (sweet potato)

Clostridium sp. on, flooding and, S4.28

Fusarium solani on, infection prior to harvest, S2.2

Macrophomina phaseolina on, infection prior to harvest, S2.2

potyviruses in, role of virus titer and aphid species population abundance in spread of S4.138

Rhizopus stolonifer on, hot-water baths for treatment of, S2.10

Sweetpotato feathery mottle virus in, host plant, aphid species and virus infection status, S2.11 Ipomoea setosa, Sweet potato virus $G$ in, S4.130 IR-4 Ornamental Horticulture Research Program,

update on 2010-2011 research in, S1.6

Iraki, N., 23

Irey, M. S., S4.73, S4.161

Iris yellow spot virus (IYSV)

analysis of N-gene sequences, in United States, S4.65

in onion

onion thrips and seasonal dynamics, S4.8 overwintering onion thrips as source of, S4.117

synergistic interaction with Tomato spotted wilt virus, $\mathrm{S} 6.8$

in vitro interaction studies using bimolecular fluorescence, S4.121

Ironwood. See Casuarina equisetifolia

Irrigation regimes

of coffee, rust and brown eye spot and, S4.27, S4.28

Geotrichum candidum on tomato and, S4.39

Irrigation water

characterizing oomycetes in irrigation ponds associated with vegetable production in southern Georgia, S4.90

isolation of Phytophthora and Pythium species from different depths of sediments in a runoff water sedimentation pond, S4.140

oomycete and bacterial pathogens in, in New York, S4.60

Phytophthora spp. in risks to ornamental nursery plants and, S4.73 stream baiting for, S2.1, S4.94

recycled, influence of Pythium aphanidermatum $P$. irregulare, and $P$. cryptoirregulare on the bacterial community in, $\mathrm{S} 1.2$

validation of water quality fluctuation patterns in runoff water containment basins of eastern and central Virginia, S4.55

Isakeit, T., S4.57, S6.2

Isard, S., S4.86

Isaria fumosorosea, for control of Sclerotinia sclero-

tiorum, S4.12

Ishiga, Y., S4.123, S4.157

Ishiguri, F., S4.141

Ishikawa, F. H., 490

Ishimaru, C. A., S4.75

Islam, K. T., S4.57

Islam, M., S6.3

Islam, M. S., S4.71

Isoflavonoid compounds, alfalfa disease resistance and, S4.105

Isothermal amplification methods. See also Loopmediated isothermal amplification procedure, overview of, S4.156

ITS (internal transcribed spacer), of Phakopsora pachyrhizi, variability of, $\mathrm{S} 4.103$

ITS 2 region, of Peronosclerospora spp. on sugarcane, S4.73

Ivors, K., 652, S4.14, S4.72, S4.73

Ivy, ground. See Glechoma hederacea

IYSV. See Iris yellow spot virus

Izumi, Y., 741

Jack, A. L. H., 478

Jackson, A. O., S4.69

Jackson, C., S4.104

Jackson, K., S4.17

Jackson, T., S5.2

Jackson-Ziems, T. A., S5.6

Jackwood, R., 306

Jacobs, J., S2.6, S4.57, S4.102

Jacobs, J. L., S4.131, S4.132, S5.8 
Jacobs, J. M., S4.151

Jaime, R., S4.58

Jalan, N., S4.58

Jalapeño pepper. See Capsicum annuum

Jama, A. N., S4.126

James, M. M., S4.58

James, T. Y., S4.162

Jang, C., S4.58, S4.69, S4.85

Janisieswicz, W. J., S4.127

Janisiewicz, W. J., S4.43, S4.58, S4.92

Jansky, S. H., 214, S4.148

Japanese andromeda. See Pieris japonica

Japanese birch. See Betula platyphylla var. japonica

Japanese knotweed. See Fallopia japonica

Jaragua grass. See Hyparrhenia rufa

Jardine, D., S4.102, S5.8

Jardini, T. M., S4.103

Jatropha yellow mosaic virus (JYMV), in Dominican

Republic, S4.79

Jecmen, A. C., S2.6

Jeffers, S., S4.125

Jensen, S., S1.4

Jeon, H., S4.144

Jeon, Y., S4.59

Jepson, P., S6.13

JGMV. See Johnsongrass mosaic virus

Ji, P., S4.30, S4.90

Jia, H., S4.146

Jia, M. H., 700

Jia, Y., 700, S4.59, S4.130

Jiang, H., S4.102

Jiang, N., 779

Jibilian, G., S4.107

Jiménez, P., S4.18, S4.112, S4.117

Jimenez-Gasco, M., S4.29

Jimenez-Gasco, M. M., S4.7

Jin, X., S4.68

Jin, Y., S4.145

Jing, L., S4.86

Jo, Y., S6.1, S6.2, S6.4

Johal, G. S., S4.102

Johnson, C., S4.134, S4.165

Johnson, D. A., S4.32, S6.8, S6.9

Johnson, E., S4.59

Johnson, K. L., S4.59

Johnson, W., S4.87

Johnson-Brousseau, S. A., S4.59, S4.60, S4.90, S4.103

Johnsongrass mosaic virus (JGMV), in maize, resis-

tance conferred by Wsm loci to, S4.114

Jomantiene, R., S4.29

Jones, J., S2.3, S4.49, S4.89

Jones, J. B., 924, S4.45, S4.55, S4.94, S4.101,

S4.108, S4.148

Jones, L. A., S4.60

Jones, M. W., S4.114

Jones, T. J., S3.3, S4.60

Jones, W., S2.9

Jonkers, W., S4.11, S4.48

Jordan, D. L., S2.4

Jordan, R. L., S4.49, S4.155

Jordan, S., S5.3

Jordan, S. A., S4.44, S4.133

Joshua, J. O., S4.60

Juglans spp.

Agrobacterium tumefaciens on

in California, S4.76

identification of sources of resistance in germplasm, $\mathrm{S} 4.78$

J. cinerea (butternut), Ophiognomonia clavigig-

nenti-juglandacearum on

effect on genetic diversity of regenerating populations, S4.13

inhibition in vitro by fungi associated with butternut, Japanese walnut, and hybrid butternut, S4.57

J. nigra (black walnut)

Geosmithia morbida on: comparison of two isolation methods for, S4.128; genetic diversity in southeastern U.S., S4.49 thousand cankers disease on, progression in Tennessee in 2010-2011, S3.3

J. regia (walnut), Cherry leaf roll virus in, in

California, S4.74

thousand cankers disease on

distribution and impact in western U.S., S4.158

pathologist's perspective on in eastern U.S., S4.158

as recently emerging disease in eastern U.S., S4.159

Julia, J., S6.2

Julian, J., S4.155

Jumpponen, A., S4.45, S4.46

Jung, G., S1.4, S4.56, S4.63, S4.105

Jungman, M. P., S4.57

Jurado-Bello, J., 974

Jurgens, A. G., S4.60

Jurick, W. M., S4.43, S4.58, S4.92, S4.127

Justino, F. B., S4.101

Juszczak, S., S4.47

Juzwik, J., S4.111

JYMV. See Jatropha yellow mosaic virus

Kaewan, S., S4.59

Kajihara, H., S4.85

Kale, S. D., S4.165

Kalia, B., S4.61

Kalih, R., 128

Kamei, E., 741

Kaminski, J., S4.56

Kaminski, J. E., S4.8, S4.111

Kamitakahara, H., S4.141

Kammeijer, K. E., S4.26

Kandel, Y. R., S4.61, S5.5

Kandouh, B., S4.61

Kang, H., 779, S4.75

Kang, S., S4.12, S4.64, S4.162, S4.166

Kano, Y., S4.23

Kantartzi, S. K., S4.138

Kanuya, E., S4.61

Karasev, A., S4.23, S4.51, S4.62, S4.101

Karasev, A. V., S4.23, S4.61, S4.93, S4.149, S6.9

Karen, K., S2.11

Karki, H., S2.5

Karki, H. S., S2.6, S2.8, S4.62

Karlov, A., S4.64

Karlov, G., S4.64

Karssen, G., 1153

Kashefi, J. N., S3.1

Kasinathan, H., S4.46

Kassen, A., S4.148

Kasson, M. T., S4.8, S4.62

Kasuga, T., S4.100

Kasugamycin

for Pseudomonas syringae pathovars on sweet cherry, S4.2

for Xanthomonas spp. on tomato, S4.129

Kasun, G., S4.39, S6.13

Katagiri, F., S4.42

Katawczik, M., S4.122

Kaur, I., S2.5

Kaushik, N., S4.62

Kawaguchi, A., S4.62

Kawara, T., S4.85

Kawasaki, T., 244, 469

Kawchuk, L. M., S4.62

Kayim, M., S4.97

Keinath, A., S4.49

Keinath, A. P., S4.153

Keller, K. E., S4.119

Kelley, J., S4.3, S4.81

Kemerait, R., S2.6

Kemerait, R. C., S2.4

Kenaley, S., S1.4

Kenerley, C. M., S6.3

Kennedy, B., S4.103

Kennelly, M., S4.46, S4.86

Kentucky bluegrass. See Poa pratensis
Kenyon, L., S4.122

Keremane, M., S4.63, S4.97

Kerns, J., S4.100, S4.111

Kessler, D., S4.63

Khalil, M. S., S4.120

Khan, M., S4.63

Khan, M. F. R., S5.6, S5.7

Khang, C., S4.165

Khokhani, D., S4.63

Kichler, J., S2.6

Kim, D., S4.76

Kim, H., S4.58, S4.85

Kim, J., S2.4, S2.5, S4.41, S4.63

Kim, K., S4.63

Kim, K. S., 147

Kim, M., S4.63, S4.102

Kim, S., S4.64

Kim, W., S4.64

Kim, Y., S4.58, S4.142

Kim, Y. K., 315, S4.18

Kinard, G., S4.71

Kinkel, L. L., S4.6

Király, L., 848

Király, Z., 848

Kirk, W., S4.33, S4.135

Kirkpatrick, B., S4.39, S6.11, S6.13

Kirkpatrick, T., S2.5

Kiss, L., 707

Kistler, C. H., S4.48

Kistler, H., S4.11

Kistler, H. C., S4.146

Kitajima, E. W., S2.7

Kiwifruit. See Actinidia spp.

Klessig, D. F., S4.75, S4.119

Kloepper, J. W., S4.144

Klopfenstein, N., S4.102

Klopfenstein, N. B., S4.63

Klosterman, S. J., 443

Kluepfel, D., S4.10

Kluepfel, D. A., 195, S4.16, S4.76, S4.78, S4.106, S6.9

Knudsen, G. R., S4.64

Knuteson, D. L., 519

Kobayashi, D., S4.11, S4.90, S4.105

Koch, K., S5.9

Kocide, for management of Pseudomonas savastanoi on olive, S4.39

Koebnik, R., 957

Koenig, S., S4.10, S4.64

Koenig, S. M., S5.6

Koffler, B. E., 662

Kogenaru, S., S4.64

Koike, S., S4.26, S6.10

Koike, S. T., 331, 443, S4.48, S4.103

Kolarik, M., S4.159

Kolkman, J. M., 1016

Komorowska-Jedrys, J., S1.2

Kon, T., S4.79

Koné, D., 733

Kong, H. S., 575

Kopsell, D. A., S4.11

Kornev, K., S4.64

Korzun, V., 560

Kosta, K. L., S4.59, S4.60, S4.90

Kota, R., S4.42

Koundal, V., S4.65

Kousik, C., S4.133

Kousik, C. S., S4.65, S4.133

Kousik, S., S4.122

Kovács, G. M., 707

Kovalsky Paris, P., S4.146

Krause, C. R., S4.144

Krebs, S., S4.65

Kreiser, B. R., S2.8

Kreitner, M. M., S4.163

Krenz, B., S4.65

Kriss, A. B., 55, 867, S4.65

Kroon, L. P. N. M., 348

Krueger, W. H., S4.39 
Kruger, E. L., 656

Kruger, G. R., S5.6

Krugner, R., S4.8

Kuar, K., S2.6

Kubota, R., S4.121

Kudzu. See Pueraria lobata

Kuehne, S. A., 575

Kumar, D., S4.58, S4.138

Kumar, N., S4.66

Kump, K., 1016

Kumquat. See Citrus japonica

Künstler, A., 848

Kunta, M., S4.66, S4.110

Kurle, J., S5.1

Kurle, J. E., S5.1

Kurowski, C., S4.115

Kusaba, M., 674

Kuykendall, L. D., S3.3

Kwak, H., S4.63

Kwan, G., S4.66

Laccaria bicolor, ectomycorrhiza on conifer seedlings colonized by dark septate endophytes and, S4.98

Laccase, Botryosphaeria spp. growth and phenolics and, S4.113

Lacey, L., S4.14

LaCrosse virus (LACV), Aedes triseriatus mosquito mating behavior and, S4.149

Lactuca sativa (lettuce) diseases observed in high tunnel and open field organic production, S6.11

Lettuce necrotic stunt virus and Tomato bushy stunt virus in, environmental factors and disease development, S4.136

Plectosporium tabacinum on, S4.125

Verticillium dahliae on, sources of, 1071

Verticillium wilt in, S6.12

LACV. See LaCrosse virus

Lafferty, J., S4.107

LaFountain, J. P., S4.2

Lagacé, M., S1.8

Lagopodi, A. L., S3.1

Lagos, L. E., S4.80

Lagrangian stochastic models, of spore trajectories within plant canopy turbulence, 1026

Laha, G. S., 222

Lakshman, D. K., 575, S3.4, S4.66, S4.85, S4.100

Lalancette, N., 421, S1.4

Lambert, D., S4.90

Lambert, K. N., S4.11

Lamiaceae essential oils, for control of Botrytis

cinerea and Penicillium expansum on apple, S4.112

Lamondia, J. A., S1.4, S4.66

Lamour, K., S2.5, S2.9, S4.109

LAMP. See Loop-mediated isothermal amplification procedure

Lance nematode. See Hoplolaimus sp.

Land management practices, tomato crop health and, 597

Landeweert, R., 140

Landi, L., 290

Landschoot, P., S4.56

Laney, A. G., 1182, S2.7

Langdon, D. H., S4.121

Lange, H. W., S4.66

Langemeier, C. B., S5.6

Langham, M. A., S5.2

Langston, D., S4.33

Langston, D. B., S2.7

Lanteigne, C., 967

Laodelphax striatellus, inoculation of Rice blackstreaked dwarf virus in maize and, S4.80

Lapato, D., S4.46

Laremore, T. N., S4.110

Larkin, R. P., S4.20, S4.67

Larson, E., S4.3

Lartey, R. T., S4.67

Latent class analysis, for assessment of assays for Squash vein yellowing virus in cucurbits, S4.122
Latent period, importance of, S4.38

Latoni-Brailowsky, E. I., S4.108, S6.3, S6.6

Latorre, B. A., S4.29, S4.34, S4.100

Laughlin, D. A., S6.3

Lawrence, A., S4.2

Lawrence, C., S5.5

Lawson, L. H., S4.64

Lazarus, C., S4.100

Le Maguet, J., 717

Le Strange, M., S4.122, S6.7

Leach, J., S4.127

Leach, J. E., 948

Leadbetter, C., S1.2

Leadbetter, C. W., S1.4

Leaf area index, Phakopsora pachyrhizi on soybean and, S4.82

Leaf miners. See Coelaenomenodera minuta

Leafhoppers, detection of phytoplasmas in, in

Colombia, S4.41

Leandro, L. F., S4.1, S4.30, S4.118

Lear, M., S3.2

Leatherleaf fern. See Rumohra adiantiformis

Lebeau, A., 733

Lebeis, A., S4.47

Lebsky, V., S6.5

Lee, H., S4.59

Lee, I., S3.2, S4.8, S4.29, S4.143

Lee, J., 547

Lee, K., S4.81

Lee, L., S4.163

Lee, M., S4.67, S4.139

Lee, M. W., 32

Lee, R. F., S4.63, S4.67, S4.97, S4.131

Lee, S., S4.59, S4.63, S5.5, S5.6

Lee, S. A., S4.67

Lee, Y., S4.59

Lefebvre, V., S2.5

Legler, S., S4.68

Legler, S. E., 707

Legumes. See also Specific species

begomoviruses in, molecular identification in southeast Asia, S4.122

Fusarium spp. on, evaluating seed treatments for control of, $\mathrm{S} 4.52$

Lehman, B., S4.67

Leifsonia xyli, on sugarcane, methods of DNA extraction for, S4.124

Leisner, S., S4.6

Lemaire, O., 717

Lemmens, M., S4.146

Lemon. See Citrus jambhiri; Citrus limon

Lenardon, S., S4.51

Leng, Y., S4.68, S4.143, S5.9

Lens culinaris (lentil), Sclerotinia sclerotiorum on,

transcriptome analysis using RNA sequencing, S4.95

Leon, G. A., S4.24, S4.103

Leonardo, L., S4.112

Leptographium spp., on Pinus spp., variation in family resistance to, $\mathrm{S} 2.9$

Leptosphaeria spp.

on canola, diagnostic assay for, S4.12

L. coniothyrium, on blackberry, effect of early floricane removal and fungicides on, S3.4

L. maculans

on canola: in seed and dockage, S4.38; timing of inoculation and, S4.28

on oilseed rape, wide hybridization for resistance transfer into, $\mathrm{S} 4.136$

Leslie, C., S4.10

Leslie, J. F., S4.120

Lesniak, K. E., S4.68

Lettuce. See Lactuca sativa

Lettuce necrotic stunt virus (LNSV), in lettuce, environmental factors and disease development S4.136

Leuconostoc mesenteroides, on sugar beet, influence of tillage systems on, $\mathrm{S} 4.115$

Leveau, J. H., S4.74, S4.139
Leveillula taurica, on tomato, in central California, S6.7

Levesque, C., S1.5, S4.101, S4.113

Lévesque, C. A., S4.22, S4.34, S4.167

Levi, A., S4.119, S4.133

Levy, J., 899, S4.141

Levy, J. G., S6.4

Levy, L., S4.15, S4.24, S4.97, S4.103, S4.156

Lewandowski, D. J., 1176

Lewis, C. T., S4.22

Lewis, R., S4.107

Lewis Ivey, M. L., S4.166, S5.7

Li, D., S4.69

Li, J., S4.69

Li, J. Z., S4.69

Li, J.-L., 1045

Li, K., 267

Li, M., 692, S4.58, S4.69, S4.85

Li, Q., S4.69, S4.70

Li, Q. J., S4.69, S4.70

Li, R., S4.70, S4.71, S4.130

Li, S., S4.68

Li, W., S4.66, S4.70, S4.123, S4.144

Li, W. H., 267

Li, X., 692, 937, S1.8, S2.7, S4.38, S4.68, S4.142

Li, Y., S1.5, S4.69, S4.70

Liberator, K. L., S4.70

Liberti, D., 506

Liebman, M., S4.1

Liess, L., S6.12

Lightle, D., 547

Lignin

alfalfa disease resistance and, S4.123

Plasmodiophora brassica progression from cortical to stele cells and, S4.29

Lim, H., S4.58, S4.69, S4.85

Lim, S., S1.5

Lima, M. F., S4.71

Lima bean. See Phaseolus lunatus

Limestone amendment, Fusarium oxysporum $\mathrm{f}$. $\mathrm{sp}$ spinaciae on spinach and, $\mathrm{S} 4.43$

Lin, B., S3.4

Lin, F., S4.142

Lin, H., S4.71, S6.3

Lin, J., S5.6

Lin, L., S4.71

Lincoln Nucleic-acid Kit (LiNK), for rapid extraction of plant pathogen DNA, S4.15

Lindeberg, M., S4.2, S4.165

Lindow, S. E., 1045

Ling, K., S4.70, S4.71

Ling, K. S., S4.133

Links, M., S4.113

Lipopolysaccharide (LPS)

plant innate immunity and, S4.116

Xanthomonas citri subsp. citri on citrus and, $n l x A$ gene and production of, $\mathrm{S} 4.140$

Xylella fastidiosa on grape and, S4.147

Little, C. R., S4.91

Liu, B., S4.72

Liu, C., 252, 692, 841

Liu, C. J., 1064

Liu, E., 779

Liu, F., 252, 841

Liu, G., S4.144

Liu, H., S4.21, S4.144

Liu, J., 779, S6.10

Liu, P., S4.119

Liu, Q., S4.72

Liu, S.-Y., 948

Liu, W., S4.130

Liu, X., 692, 779, S4.21

Liu, X. L., S2.2

Liu, Y., 779, S2.7, S4.139, S5.6

Liu, Z., S2.3, S2.7, S4.15, S4.22, S4.71, S4.72,

S4.97, S4.108, S4.131, S4.142, S4.156

Liu, Z. H., 498, 539

Live oak. See Quercus agrifolia

LNSV. See Lettuce necrotic stunt virus 
Loblolly pine. See Pinus taeda

Locke, J. C., S4.144

Lockhart, B., S4.82

Loconsole, G., 1168

Logrieco, A., S4.120

Lolium spp. (ryegrass), Magnaporthe oryzae on GFP-tagged, S4.69

Magnaporthe oryzae on, effects of relative humidity on infection, conidia production, and mycelial colonization, $\mathrm{S} 1.5$

silicon-induced resistance in, $\mathrm{S} 4.96$

Lombard, K., S4.84

Lommel, S. A., S4.119

London rocket. See Sisymbrium irio

Lookabaugh, E., S4.72

Loop-mediated isothermal amplification procedure

(LAMP)

for Bean pod mottle virus, S4.20

for Candidatus Liberibacter solanacearum on potato and psyllids, 899

for Clavibacter michiganensis subsp.

michiganensis on tomato, S4.141

for High plains virus, S4.6

for Rhizoctonia spp., S4.91

Lopez, G., S4.112

Lopez, P., S6.4

Lopez-Ochoa, L. A., S4.83

Los, L., S1.3

Lotrakul, P., S4.105

Lourenço, S. d., S4.25

Louws, F., S3.2, S4.72

Louws, F. J., S4.31, S4.57, S4.153

Lovelock, D., S4.72

Loyd, A., S4.73

LPS. See Lipopolysaccharide

Lu, J., 1094

Lu, S., S2.7, S4.33, S4.73, S4.139

Lu, X., S4.65

Lu, X. H., S4.102

Lu, Y., S4.80

Luck, J., 1034

Luckert, D., 683

Lujan, M., S4.89

Lujan, P. A., S4.73, S6.10

Luke, E., S6.13

Luo, M., S4.40

Luo, W., S4.73

Lupien, S., S4.125

Lupinus spp. (lupin), Colletotrichum acutatum on,

assessing disease symptoms in Andes, S4.37

Lurvey, E., S1.6

Luster, D., S4.64

Luster, D. G., S4.73

Lutz, L., S4.6

Lydon, J., 575

Lympus, K., S4.96

Lynn, N., S4.74

Lysobacter enzymogenes, for control of Crypho-

nectria parasitica, type IV pilus and, S4.90

Ma, L., S4.11, S4.48, S4.104

Ma, L. M., S4.30, S4.44

Ma, W., S4.74, S4.158

Ma, X, S5.7

MAB. See Marker-assisted breeding

Maccree, M. M., S4.76

MacDonald, B., S4.96

MacDonald, J. D., S4.95, S6.12

MacDonald, W. L., S3.4

MacFarlane, S., S4.120

MacGuidwin, A., S4.26, S4.45

MacGuidwin, A. E., 519

Machado, F., S4.32

MacKasmiel, L., S4.74

Macknicki, C. J., S4.100

MacPhail, A., S4.62

Macroarrays, for detection of onion bulb rot pathogens, S4.125

Macrophomina phaseolina on flowering dogwood, bacterial biocontrol agents for control of, $\mathrm{S} 4.74$

on green gram, synergistic effects of arbuscular mycorrhiza, Glomus constrictum, nitrogen fixing bacteria Rhizobium sp. and, $\mathrm{S} 4.85$

impact of temperature on growth and development of, S5.9

on soybean, effect of environment and genotype on, $\mathrm{S} 2.3$

on strawberry, control of, S4.80

on sugar beet, S4.115

on sweet potato, infection prior to harvest, S2.2

Madden, L. V., 55, 867, S4.5, S4.28, S4.65, S4.105,

S4.135, S5.8

Madeira, N. R., S4.71

Maeda, M., S4.85

Maffia, L. A., S4.82, S4.112

Magarey, R., S5.3

Magarey, R. D., S4.27

Magculia, N. F., S4.74

Magnaporthe spp.

comparative genomic analysis of using DSYND, S4.104

M. grisea, on triticale, pathogenic, mating type, and population structure of, $\mathrm{S} 4.124$

M. oryzae

on barley: MoHyr1 and MoyAP1, reactive oxygen species and, S4.55; novel locus Rmo 2 conditioning resistance to host-specific subgroups, 674

characterization of proteome during appressorium formation, $\mathrm{S} 4.41$

Hsp104 and pathogenicity and gene regulation in, S3.4

identification of blast resistance genes for management of, S4.130

natural variation and evolution of avirulence genes in, S4.59

polyubiquitin and growth, development and pathogenicity of, S4.87

on rice: disease reactions of IRRI near-isogenic rice to U.S. isolates, S4.37; effector proteins and delivery into living cells, S4.165; ianjingyeshengdao cultivar, mapping resistance genes of, 779; identification of $P i b$ gene in National Small Grains Collection and, 700; methods for identifying and quantifying partial resistance, S4.135; nep1like fungal toxin targets a conserved ubiquitin-like protein and necrotic cell death, S4.131; Pik- $h$ and resistance, S4.142; resistance inducers and, S4.126

on ryegrass: effects of relative humidity on infection, conidia production, and mycelial colonization, S1.5; GFP-tagged, S4.69; silicon-induced resistance in, S4.96

searching for the sensor of reactive oxygen species in, $\mathrm{S} 3.2$

on wheat: as emerging threat, S5.3; probability of introduction into United States, S4.27

Magnetic capture hybridization, and real-time PCR

for Agrobacterium vitis on grape, S4.59

Maguire, I., S6.4

Mahaffee, W. F., S4.91, S6.8

Mahanil, S., 83

Maharaj, N. N., S4.74

Mahovic, M., S4.9

Mahuku, G., S6.6

Maier, R., 662

Maize. See Zea mays

Maize chlorotic mottle virus (MCMV), in corn,

development of infectious clones for, S4.18

Maize dwarf mosaic virus (MDMV), real-time PCR for, S4.89

Maize fine streak virus (MFSV), molecular mecha-

nisms of replication and infection, $\mathrm{S} 4.25$

Maize rayado fino virus (MRFV)

in maize, novel sources of resistance to, S5.10 in Nicotiana benthamiana, selective RNA packaging of, $\mathrm{S} 4.85$

Makarov, A., S4.57

Maketon, C., S6.10

Malapi-Wight, M., S6.1

Maldonado, A., S4.75

Malik, N., S4.110

Mallowa, S., S4.75

Mallowa, S. O., S4.142, S5.7

Malmstrom, C. M., S4.157

Malpica-Gutierrez, A. M., S4.110

Malus domestica (apple)

Alternaria spp. on

A. alternata on: dynamics of growth regulators during infection by, S4.21; effect of host physiology on, 769

in Australia, S4.51

in Italy, comparison with A. mali and other AM-toxin producing strains, 1130

Botryosphaeria dothidea on, S4.127

Botrytis cinerea on

endogenous ethylene biosynthesis and resistance to, 135

Lamiaceae essential oils for control of S4.112

molecular characterization of pyraclostrobin resistance and structural diversity of the cytochrome $b$ gene in, 315

Brassicaceae seed meal for control of apple replant disease, $\mathrm{S} 4.77$

Colletotrichum spp. on

C. acutatum on: factors involved in outbreaks, S5.6; virulence and genotypic diversity of strains from New Hampshire, S4.91

C. gloeosporioides on, factors involved in outbreaks, S5.6

in Indiana, S4.64

Erwinia amylovora on acyl carrier protein and virulence, $\mathrm{S} 4.67$ streptomycin-resistant, S4.60

Neonectria galligena on, climatic rule and fuzzy sets to model geographic distribution of climatic risk for, 147

Penicillium spp. on

$P$. expansum on: bin-top sprays for controlling, S1.7; Lamiaceae essential oils for control of, S4.112; organic chlorine for control of, S4.125; pyrimethanil resistance in, $\mathrm{S} 4.18$

new species on stored fruit, S4.92

sensitivity of isolates from decayed fruit to postharvest fungicides, S4.43

Phacidiopycnis washingtonensis and Sphaeropsis pyriputrescens on, PCR assays for, S4.109

plastoquinone partitioning in chloroplast and disease resistance in, $\mathrm{S} 4.110$

Pseudomonas viridiflava on, detection using specific designed primers, S4.117

Venturia inaequalis on, real-time PCR for detection and quantification of trifloxystrobinresistant strain, $\mathrm{S} 4.128$

Malvick, D., S4.112, S5.8

Malvick, D. K., S4.75, S4.102

Mangifera indica (mango)

Colletotrichum spp. on, in Colombia, S4.18

fungi isolated from diseased inflorescences of, in Puerto Rico, S4.108

Mango. See Mangifera indica

Mangravita-Novo, A., 185

Mani, K. K., S4.75

Manjunath, K., S4.67

Mann, H., S4.15

Mannosyltransferase, characterization of in Fusarium graminearum, $\mathrm{S} 4.95$

Manosalva, P. M., S4.75

Mansfield, M., S4.92

Mansfield, M. A., S1.7

Manulis-Sasson, S., 23, S4.20

Maoka, T., S4.23 
Marafivirus, identification of new from buttercup, S4.2

Marasas, C., S4.76

Marçais, B., 47

Marcel, T. C., 1086

Marek, L. F., S4.12

Marek, S., S4.39

Marek, S. M., S4.24, S4.89

Marella, H., S5.9

Margenthaler, E., S4.2

Margosan, D. A., 83

Marin, P., S4.27

Markell, S., S4.42, S4.102, S5.8

Marker-assisted selection (MAS)

for disease resistance in wheat and barley, 560

for resistance of rice against Magnaporthe oryzae, 700

Marois, J. J., 794, S2.11, S4.113, S4.114, S4.163

Maroof, S., S4.77

Maroon-Lango, C. J., S4.76

Marra, R. E., S1.5, S4.26

Marrone, P. G., S4.119

Marroquin-Guzman, M. R., S6.4

Marsden, C., S4.78

Marsh crab, purple. See Sesarma reticulatum.

Marshall, J. M., S6.7

Marthe, F., S4.136

Martin, A., S5.1

Martin, D., S3.2

Martin, F. N., 229, 331, S4.76

Martin, R., S2.11

Martin, R. R., 547, S4.96, S4.119

Martínez, E., S6.4

Martinez-Espinoza, A. D., S4.76

Martinez-Gonzalez, C. R., S4.110

Martinez-Uribe, O. A., S4.76

Martins, E. C., S4.138

Martins, S. C. V., 892

Martinuz, A., 260

Marutani-Hert, M., S4.76

Maruthachalam, K., 443, 1071, S4.48, S4.77, S4.109

Mass spectrometry, for virus-vector interface, S4.164

Masunaka, A., 741

Masuya, H., S1.6

Mating type loci

biological control of Aspergillus flavus on corn and, S4.28

genetic analysis of Sclerotinia homoeocarpa populations and, S4.95

Matthews, B. F., S4.77

Matthiesen, R., S4.1, S4.77

Mattupalli, C., S4.77

Matveeva, E. M., 620

Mauch-Mani, B., S4.92

Maul, J. E., S3.4, S4.100

Mavrodi, D., S4.141

Mavrodi, D. V., 403

Mavrodi, O., S4.141

Mavrodieva, V., S4.108

Maximova, S. N., S4.110

May, M., S4.115

Mayer, R. T., S6.2

Mayorquin, J., S4.123

Mazzaglia, A., 827

Mazzola, M., S4.77, S4.109

Mbofung, G. C., S4.1

McAninch, G., S4.89

McAvoy, T., S4.78

McBeath, J. H., S4.69

McBride, S. A., S4.78

McCann, D. P., S3.4

McClean, A. E., 195, S4.76, S4.78, S6.9

McClean, P. E., 94

McClure, M., S4.86

McCluskey, K., S4.167

McCollum, G. G., S4.153

McConnell, M., S4.78

McCormick, S., S1.2, S4.146

McCreight, J. D., S4.136

McDaniel, R., S2.6
McDonald, B., S4.114

McDonald, B. A., S4.97

McDonald, G., S4.102

McDonald, M., S4.29, S4.46, S4.78, S4.108

McDuffee, D., S4.31

McFarland, K. A., 421, S1.4

McGrath, J., S5.5

McGrath, M. T., S1.5, S1.6, S4.78

McGuire, I. C., 478

McHale, L., S5 6

McInnes, B., S2.2

McIntyre, L., S5.9

McKay, A. H., 528

McKenna, L. F., S4.100

Mckenna, L. F., S3.4

McLaughlin, J., S1.2

Mclean, K., S4.120

McLeod, A., 204

McMahon, M. B., S4.73

McManus, P., S4.134

McManus, P. S., 656

McMillan, M., S4.133

McNally, R. R., S4.79, S4.142

Mcnally, R. R., S5.7

McNellis, T., S4.67, S4.110

McOwen, N., S4.143

McPherson, B. A., S5.3

McRoberts, N., S4.6, S4.7, S4.19, S4.24, S4.25,

S4.99, S4.162, S4.163, S6.8, S6.13

McSpadden Gardener, B., S4.10

McSpadden Gardener, B. B., S4.115, S5.2, S5.8

McTaggart, A., S4.103

MCW-2, for root-knot nematodes on tomato and

cucumber, S4.135

MDMV. See Maize dwarf mosaic virus

Meador, C. B., S4.31

Mealybugs

ecology of, grapevine leafroll-associated viruses and, S6.13

on grape, foliar insecticidal treatments for, S3.3

statewide survey and management of its vector in Virginia, S4.60

transmission of six ampeloviruses and two vitiviruses to grapevine by, 717

Medicago spp.

M. sativa (alfalfa)

isoflavenoid compounds and disease resistance in, S4.105

lignin modification and tolerance to soilborne fungal pathogens in, S4.123

Phoma medicaginis on: characterization of mutant forming hyaline pycnidia, S4.24; poly(A) RNA polymerase gene disruption and, S4.24

Verticillium spp. on, diagnostic assay for, S4.12

M. truncatula, Tnt1 retrotransposon insertion lines, loss of abaxial leaf epicuticular wax in, S4.124

Medrano, E. G., S4.79

Meeker, J., S4.87

Mefenoxam, for Phytophthora infestans, sensitivity

of recent strains in U.S., S4.84

Megen, H. van, 1153

Mehl, A., S4.19

Meksem, K., S4.138

Mekuria, T. A., S4.79

Melander, C., S4.70

Melanson, R., S2.5

Melanson, R. A., S2.8

Melcher, U., 166, S4.49, S4.58, S4.155

Melcher, U. K., S4.33, S4.114, S4.115

MeLCV. See Merremia leaf curl virus

Melgarejo, T. A., S4.79

Meliola sp., on native Fabaceae in Brazil, S4.111

Mellinger, H. C., S4.133

Melnick, R. L., S3.4

Meloidogyne spp. (root knot nematodes) on Arabidopsis thaliana, host gene silencing pathways and, S4.130
M. arenaria, on eggplant, grafting for management of, S4.104

M. enterolobii, on noni, Chinese eaglewood, and clove in China, $\mathrm{S} 4.37$

M. fallax, primers specific to, amplification of Meloidogyne minor with, S4.86

host gene silencing pathways and, S5.9

M. incognita on cotton, nitrogen rate and Telone II treatment, S2.5

grafting for management of, S4.153

induction of resistance against, 260

parasitism genes of, functional analysis in Arabidopsis thaliana, S4.111

on soybean, recombinant inbred lines for resistance against, $\mathrm{S} 4.138$

infection rate in tobacco expressing RNAi targeted

to nematode parasitism gene and, S4.107

$M$. javanica, on tomato and cucumber, optimizing use of MCW-2 for control of, S4.135

M. kikuyensis, on sugarcane, morphology and molecular biology, $\mathrm{S} 4.34$

on melon, grafting for management of, S4.119

M. minor, amplification of with primers specific to Meloidogyne fallax, S4.86

on potato, cultivar susceptibility, S4.61

on tomato

impact of divergent land management practices on crop health, 597

management using resistant rootstocks, $\mathrm{S} 4.78$

Melon, root-knot nematodes on, grafting for

management of, S4.119

Melzer, M., S4.131

Melzer, M. J., 122, S1.6

MeMV. See Merremia mosaic virus

Menasha, S. R., S1.6

Mendes, O., 635

Mendi, R. C., S4.106

Mengesha, B. G., S2.9

Mengiste, T. D., S2.9

Mentha spp. (min), Verticillium dahliae on disease development and, S6.9 population biology of, S6.8

Mera, J., S4.10

Merremia leaf curl virus (MeLCV), in Merremia spp., in Puerto Rico, S4.51

Merremia mosaic virus (MeMV), in Merremia spp., in Puerto Rico, S4.51

Merremia spp., Merremia leaf curl virus, Sweet potato leaf virus, and Merremia mosaic virus in, S4.51

Mersha, Z., S4.79, S4.80

Mertely, J., S4.107

Mertely, J. C., S4.80

Mescher, M. C., S4.150

Mesquini, R. M., S4.80

Metabolomics

for analysis of rhizosphere, S4.159

for resistance in coast live oak to Phytophthora ramorum, S5.3

Metagenomics

for analysis of rhizosphere, S4.159

for complex microbial communities, S4.159 in fungal community ecology, S4.159

of fungal diversity associated with dogwood, S1.6 for nonculturable oomycetes, S4.117 use of for plant pathology research, S4.160

Metarhizium brunneum, for control of Sclerotinia sclerotiorum, S4.12

Metconazole, for Sclerotinia sclerotiorum, characterization of sensitivity in north central United States, S4.4

Methacrylate, protein localization in life stages combined with plant tissues and, 990

Methanol oxidase, Moniliophthora perniciosa on cacao and, S4.88

Methyl bromide

alternatives to for strawberry, S4.86 grafting as alternative to, $\mathrm{S} 4.120$ 
Mexican fruit fly. See Anastrepha ludens

Meyer, F. W., S1.7

Meyer, G. A., S4.125

Meyerpeter, M. B., S2.8

MFSV. See Maize fine streak virus

MgCYP51, Mycosphaerella graminicola resistance to DMI fungicides and, S4.41

Mian, R., S5.6

Miao, H., S4.80, S5.7

Michael, J. L., S3.2

Michaelian, M., S4.137

Michailides, T. J., S4.83

Michel, A., S4.25

Michler, C., S4.57

Microarrays

for detection of fungal pathogens involved in young vine disease of grape, $\mathrm{S} 4.124$

progress in development of universal for plant viruses, S4.49

universal plant virus, development and validation of, S4.155

Microbe-associated molecular pattern (MAMP), Xan-

thomonas campestris on Arabidopsis and, S4.116

Microbe-associated molecular pattern (MAMP)-

triggered immunity (MTI), VEGEVADERS game and, S4.2

Microdochium spp., on barley, prevalence and impact in U.K., S4.98

Micro-Raman spectroscopy, for characterization of

biofumigated Ralstonia solanacearum cells, 105

Microsatellite markers

for Anisogramma anomala on Corya spp., S1.4

for Bipolaris sorokiniana, S2.3

Candidatus Liberibacter asiaticus genetic diversity and structure and, S6.3

characterization of Phytophthora infestans lineages in U.S. and, S4.110

for Fusarium virguliforme on soybean, S4.132 genetic analysis of Sclerotinia homoeocarpa populations and, S4.95

for Waitea circinata var. circinata on turfgrasses, S1.6

Microscopy, for characterization of biofumigated

Ralstonia solanacearum cells, 105

Microsequence analysis, of Fusarium spp., S4.39

Mideros, M., S4.117

Mideros, M. F., S4.80

Mideros, S. X., 787

Miedaner, T., 128, 560

Mila, A., S4.12, S4.122

Mile-a-minute. See Persicaria perfoliata

Miles, C., S6.11

Miles, L. A., S4.36

Miles, T. D., S4.36, S4.106, S4.150

Milgroom, M. G., 83, 997

Milkweed, green. See Asclepias viridis

Millas, P. A., S4.41, S4.81

Mille, S. A., S5.10

Miller, G. L., S4.8

Miller, N. A., S2.9, S4.109

Miller, S., S5.1

Miller, S. A., 177, S4.10, S4.153, S5.7

Miller, S. J., S1.6

Miller-Butler, M. A., S2.8, S4.111

Millett, B. P., S4.15

Milling, A., S4.56, S4.121, S4.151

Milus, E., S4.81

Min, B.-E., 166

Minerals, Xylella fastidiosa interactions with host plants and, S4.157

Minsavage, G., S4.45

Minsavage, G. V., S4.108, S4.148

Mint. See Mentha spp.

Mintoff, S. J., S4.81

Minzenmayer, R. R., S4.57

Mirik, M., S4.137

Mirjafary, N., S4.9

Miscanthus $\times$ giganteus

diseases of in Mississippi, S4.45 foliar lesions on, S2.5

frequence of fungi associated with in 2011, S4.45

Pithomyces chartarum on, screening for fungi-

cide control and, S4.2

Mishra, B., 222

MitchelL, A. J., S5.9

Mitchell, P. J., S4.45

Mitchell, T., S4.39, S4.161, S5.3, S5.5

Mitchum, M. G., S4.107

Mitkowski, N., S4.45

Mitochondrial haplotype analysis, for differentiation

of isolates of Phytophthora cinnamomi, 229

Mitra, A., S5.4

Mitra, R. M., S4.151

Mixon, J., S4.14

Miyamoto, Y., 741

Miyao, E., S6.7

Miyao, E. M., S4.74

Mizubuti, E., S4.32

Mizubuti, E. S., S4.112

Mlotshwa, S., S4.165

MLST. See Multilocus sequence typing

Mo, T., S4.50

Mo, X., S4.80, S4.81

Mock, R., S4.71

Modeling

aphid vector flights and Potato virus $Y$ control, S4.148

area under the disease progress stairs, 381

effect of soybean rust on soybean yield using the CSM CROPGRO: Soybean, S4.101

of eradicative and management strategies for pale cyst nematode on potato, $\mathrm{S} 4.64$

of Erysiphe necator on grape, uncertainty and, S4.25

Erysiphe necator on grape, S6.8

of flush-to-flush transmission of huanglongbing, S4.23

of fungicide resistance, concurrent, alternating, and mixture use of two high risk fungicides as resistance management strategy, $\mathrm{S} 4.53$

of Fusarium circinatum on Monterey pine, S4.99

of Fusicladium carpophilum on nectarine, sporulation of, relative humidity and temperature and, 421

of geographic distribution of climatic risk for European canker on apple, 147

information in multiscale epidemiological models, S4.161

lagrangian stochastic models, of spore trajectories within plant canopy turbulence, 1026

of longitudinal data, 1016

of microbial communities, S4.160

probability of introduction of Magnaporthe oryzae on wheat into U.S., S4.27

rank regression for analyzing ordinal qualitative data for treatment comparison, 1064

SkyBit 2011, reliability and accuracy of in Pennsylvania, S4.49

sporulation of Fusicladium carpophilum on peach, $\mathrm{S} 1.4$

sustainable grape pest management using weather data and disease risk models, S4.91

time-dependent infectivity and flexible latent and infectious periods in compartmental models, 365

of Tomato spotted wilt virus in tomato, S4.19

wavelet analysis, for spatial and temporal analysis of epidemics, S4.65

Moersfelder, J., S4.78

Moktan, K., S1.1

Moldakimova, N. A., S4.81

Moleleki, L., S4.109

Molina-Gayosso, E., S4.110

Mollov, D., S4.82

Molnar, S. J., 683

Molnar, T., S1.2

Molnar, T. J., S1.4

Momol, M. T., 924
Mondal, S. N., S4.82

Monfort, S., S2.9

Monfort, W., S4.113

Monilinia spp.

M. fructicola

dual fungicide resistance in, fungicide-mediated transposition of genetic elements and, S4.21

inhibitory effects of 2-aminoimidazole compounds on, S4.70

on peach: fine-scale genetic structure of populations within tree canopies, S4.36; fruit surface chemistry and susceptibility to, S4.139; new mechanism of DMI fungicide resistance in, $\mathrm{S} 2.2$

screening plum for resident bacteria with biocontrol activity against, $\mathrm{S} 4.58$

sensitivity to sterol demethylation inhibitors and CYP51 promoter insertion analysis, S4.68

M. vaccinii-corymbosi, on blueberry population genetics in United States, S4.17 propiconazole resistance and, S4.119

Moniliophthora spp.

M. perniciosa, on cacao, secreted methanol oxidase and pectin metabolism, $\mathrm{S} 4.88$

M. rore, on Theobroma cacao, S3.4

Monis, J., S4.82

Monitoring network, in Canada for microbial phytopathogens in air and rain samples, S4.22

Monteil, C. L., S4.160

Monterey pine. See Pinus radiata

Montoya, Y., S4.118

Moorman, G. W., S1.2

Mooyman, P., 1153

Moral, J., 974, 982

Morales, Z., S4.82

Moreira, A. S., S4.82

Moreira, E. N., S4.82

Moreira, W. R., 892

Moreno, A., 114

Moreno-Valenzuela, O. A., S4.83

Morgan, D. P., S4.83

Morgan, G. D., S4.57

Mori, S. R., S5.3

Morii, S., S4.125

Morillo, E., S4.94

Morin, E., 627

Morinda citrifolia (noni), Meloidogyne enterolobii on, in China, S4.37

Moriyama, H., S4.126

Morris, C. E., S4.160

Morris, J. G., S4.23

Morse, A., S5.9

Mortensen, L., S4.116

Mørtz, E., 878

Mosch, M., S4.136

Mosquitoes

LaCrosse virus and mating behavior of, S4.149 molecular basis of vector competence, S4.149

Mostert, G., 204

Mota, S. F., 490

Motavalli, P., S4.45

Mott, D. A., S4.57

Mou, B., 443

Movement tubules, of Cowpea mosaic virus, S4.44

Moyer, M. M., S4.42, S4.83

MRFV. See Maize rayado fino virus

MSMA, for monitoring Penicillium expansum, S4.125

MTI. See Microbe-associated molecular pattern

(MAMP)-triggered immunity

Muddiman, D. C., S4.41, S4.87

Mudge, J., S2.9, S4.109

Muehlbauer, G. J., S4.146

Al-Mughrabi, K. I., S1.5

Mukiyanova, G. S., S4.81

Multer, W. L., S4.57

Multilocus sequence typing (MLST), importance of, Xylella fastidiosa as example of, 456 
Multiplex assays, for detection of citrus pathogens, S4.131

Multiplex real-time PCR

for Asian prunus viruses, Plum bark necrosis stem pitting associated virus, and Peach latent mosaic viroid, $\mathrm{S} 4.71$

for distinguishing among Cherry leafroll virus,

Grapevine fanleaf virus, and Tomato ringspot virus, $\mathrm{S} 4.20$

for multiple seedborne spinach pathogens, S4.38

Multiscale epidemiological models, information in, S4.161

Multivariate mixed linear modeling, of longitudinal

data, 1016

Munck, I. A., S4.84

Mundt, C. C., S4.161

Munkvold, G. P., S4.30

Munoz, A., S4.84

Munyaneza, J., S4.164

Muramoto, J., S4.77

Murolo, S., 290

Murphy, J. A., S1.3, S1.7

Murphy, J. F., S4.84, S4.127

Musa spp. (banana and plantain)

Banana bunchy top virus and Cucumber mosaic virus in, $\mathrm{S} 4.87$

Fusarium oxysporum f. sp. cubense on genome sequence of tropical race 4 strain II5, S4.11

silicon and resistance to, $957, \mathrm{~S} 4.40$

Muskmelon. See Cucumis melo

Musson, G., S4.84

Mustard meal, for black root rot disease complex on strawberry, S4.72

Musungu, B. M., S4.84

Muthukumar, V., 166

Myclobutanil, for Venturia inaequalis, CYP51A1

overexpression and resistance, $\mathrm{S} 4.128$

Mycosphaerella spp.

M. dearnessii, on white pine, S4.84

M. fijiensis, polyketide synthase gene clusters, phytotoxin production and, S4.86

M. graminicola, molecular mechanisms responsible for the decline in sensitivity to DMI fungicides in, $\mathrm{S} 4.41$

Mycotoxins. See also Specific toxins

Aspergillus flavus on coconut and, detection using ammonia treatment, S4.1

produced by Aspergillus section Nigri species, effect of drying methods on incidence, S4.89 production during infection of cereals, S4.146 synthesis by Fusarium graminearum, S4.146

Myers, J. R., S4.93, S6.9

Myers, K. L., S4.28, S4.84, S4.110

Myers, M. E., S4.47

Myriogenospora spp., on perennial grasses, S4.14

Myrta, A., 1108

Mysore, K. S., S4.123, S4.157

Myzus persicae (green peach aphid), GFP-tagged

Cucumber mosaic virus expression in Nicotiana

benthamii following transmission by, S4.65

Na, F., S4.123

Nachappa, P., 41

Naegele, R. P., S4.85

Nagy, L. G., 707

Nahar, M. S., S4.153

Naidu, R. A., S4.61

Nakaho, K., S4.85

Nakhla, M. K., S4.24, S4.66, S4.103

Nalanthamala vermoesenii, on palms, in California, S6.12

Nam, J., S4.58, S4.69, S4.85

NAM populations. See Nested Association Mapping (NAM) population

Nan, T., S4.11

NAPPFAST modeling system, for probability of

introduction of Magnaporthe oryzae on wheat into U.S., S4.27
Nargi, F., S4.15

Narváez, D. F., 794

Narvaez, M., S6.2

Nascimento, K., S4.40

Nascimento, K. J. T., 957, 112

Nash, T. D., 1079

Natilla, A., S4.85

National Clean Plant Network (NCPN)

diagnosing and cleaning up viruses in imported fruit tree nursery stock and, S4.154

industry's perspective on, S4.155

new threats to fruit tree industry and, S4.154

overview of, S4.154

Plum pox virus and, S4.154

quantifying economic benefits to tree fruit industry in Pacific Northwest, S4.155

National Plant Diagnostic Network (NPDN), expanded analysis of national repository, S6.13

National Plant Germplasm System (NPGS), overview of, S4.166

National Plant Protection Laboratory Accreditation

Program (NPPLAP), citrus greening detection assay of, $\mathrm{S} 4.108$

Natraj Kumar, P., 222

Natsuaki, T., S4.23

Navabi, A., 434

Navarrete, F., S4.85

Navarrete, F. Navarrete, F., S2.10

Navi, S. S., S4.86

Navia Gine, P. A., S 2.8

NE. See Necrotrophic effectors

Necrosis and ethylene-inducing peptide1 (Nep1)-like protein. See Nep1-like protein

Necrotrophic effectors (NE)

Stagonospora nodorum on, host gene interactions and, 94

from Stagonospora nodorum on wheat, host sensitivities and, 498

Nectarine. See Prunus persica var. nucipersica

Neeraja, C. N., 222

Neher, O. T., S4.115

Nelson, A., S4.113, S4.162

Nelson, B., S4.145, S5.8

Nelson, B. D., S4.4, S4.93, S4.102

Nelson, B. Jr., S4.145

Nelson, E. B., 478, 588

Nelson, M. E., S4.72, S4.137

Nelson, N. P., S4.161

Nelson, R. J., 787

Nelson, R. S., 166, S4.6, S4.156

Nematodes. See also Specific species

DNA sequence-based identification method for S4.50

extraction of from corn, comparison of methods and root types, S5.2

immunocytochemical procedure for protein localization in life stages combined with plant tissues, 990

Neofusicoccum spp.

$N$. mediterraneum, on pomegranate, $\mathrm{S} 4.83$

$N$. parvum, on blueberry, influence of temperature on canker development, S4.34

Neonectria galligena, on apple, climatic rule and

fuzzy sets to model geographic distribution of climatic risk for, 147

Neotyphodium spp., on grasses, hybridization and evolution of, S4.160

Neovossia horrida, on rice, field evaluation of

fungicides for control of, S4.144

Nep1-like protein, Magnaporthe oryzae on rice and, S4.13

Nephelium lappaceum (rambutan), Gliocephalotrichum spp. on

G. bulbilium on, persistence of, S6.6

scanning electron microscopic analysis of speciation in, S6.3

G. simplex on, persistence of, S6.6

Nerium oleander (oleander), Xylella fastidiosa on, realtime PCR for detection and quantification of, S4.48
Nested Association Mapping (NAM) population, screening for resistance to Phytophthora sojae,

Fusarium graminearum and Pythium irregulare in, S5.9

Nester, S. E., 761, S4.13

Nettle caterpillar. See Parassa vitidissima

Network models, for understanding micropolis,

S4.160

Neufeld, K., S4.86

Neurospora crassa, ATR1 gene and cercosporin resistance in, $\mathrm{S} 4.53$

Neves, F. W., S4.82

Newcomb, M., S4.145

Newman, M., S4.35, S4.116

Next Generation Sequencing

for detection of Phakopsora pachyrhizi from metagenomic samples, $\mathrm{S} 4.35$

for detection of Pythium ultimum from metagenomic samples, S4.35

reference biological collections and, S4.167

Nezara viridula, transmission of Pantoea agglomer-

ans by, $\mathrm{S} 4.79$

Nga, N. T. T., 674

N'Guessan, C. A., 733

Ngugi, H., S4.52

Ngugi, H. K., 272, S4.49, S4.67

Nguyen, K., S6.10

Niblack, T. L., S5.4

Nichols, R. L., S4.57

Nicolas, M. E., S4.125

Nicotiana spp. (tobacco)

ATR1 gene and cercosporin resistance in, S4.53

$N$. benthamiana

Euphorbia mosaic virus Yucatan Peninsula derived vector in, virus-induced gene silencing and, S4.83

Maize rayado fino virus in, selective RNA packaging of, $\mathrm{S} 4.85$

PSBO1 of, interaction with Alternanthera mosaic virus, $\mathrm{S} 4.58$

Phytophthora parasitica var. nicotianae on, rapid microbioassay for discovery of antagonistic bacteria for, 267

Potato virus $Y$ in, $\mathrm{S} 1.4$

Ralstonia solanacearum on comparison with strains from vegetables, S4.122 effect of temperature on resistance, $\mathrm{S} 4.12$

Tomato bushy stunt virus in, hypersensitive response and, S4.5

up-regulation of antioxidants in by hydrogen peroxide, suppression of necrotic disease symptoms and, 848

Nie, X., S4.149

Nielsen, J. D., S4.16

Nielsen, L., S4.98

Niem, J., S6.11

Nieuwelaar, A. V., S4.78

Nightengale, S. P., S4.18

Nigro, F., S4.109

Nikolaeva, E., S4.64

Nikolaeva, O. V., S4.62, S4.93, S6.9

Niks, R. E., 1086

Ning, Y., 779, S4.165

Nischwitz, C., S4.86, S6.11

Nissen, L. D., S6.4

Nita, M., S3.1, S3.3, S4.60

Nitrogen fertilization

Colletotrichum cereale on annual bluegrass and, S1.7

Telone II application for cotton nematodes and, S2.5

Njambere, E. N., S1.6

Njau, P., S4.145

NlxA gene, Xanthomonas citri subsp. citri on citrus and, and production of lipopolysaccharide and extracellular polysaccharide, motility, biofilm formation, and stress resistance, $\mathrm{S} 4.140$

Noar, R. D., S4.86 
Noling, J. W., S4.86

Nolte, P., S4.149

Nong, G., S4.108

Nonhost resistance, against Puccinia emaculata, on switchgrass, S4.123

Noni. See Morinda citrifolia

Noor, A., S5.7

Norman, D. J., 185, 924, S4.101

Norton, G., S4.10, S4.153

Norton, G. W., S4.107

Notsu, A., S4.85

Novinscak, A., 967

Novitsky, L., S1.8

Nowogrodzki, A., S4.18

NPDN. See National Plant Diagnostic Network

NRPS genes, Cochliobolus sativus virulence and,

S4.68

NtpR gene, Burkholderia glumae toxoflavin produc-

tion and, S2.8

Nunney, L., 456

Nutter, F., S6.13

Nwugo, C. C., S4.71

Oak. See Quercus spp.

Oak, S. W., S2.1

Oakley, T. R., S4.69

Oat. See Avena sativa

Oat blue dwarf virus (OBDV), coat protein expres-

sion strategy of, $\mathrm{S} 4.33$

Obasa, K., S4.86

OBDV. See Oat blue dwarf virus

O'Brien, D., S1.4, S4.8

Oceanic Niño index (ONI), variability in Fusarium

head blight epidemics and, 55

Och1 gene, characterization of in Fusarium grami-

nearum, $\mathrm{S} 4.95$

Ochoa, J. B., S4.94, S4.118

Ochoa Corona, F. M., S4.5, S4.6, S4.20, S4.89

Ochoa-Corona, F., S4.155

Ocimum spp. (basil)

increased $\mathrm{CO}_{2}$ and temperature effects on

Alternaria leaf spot and black spot of, S4.94

Peronospora belbahrii on

evaluating fungicides for control of, S1.3

peroxidase, total phenolics, and host resistance, S4.79

Ockey, S., S4.53

OCM1, flagellar phylogenetics and, S4.101

O'Connel, R., S4.17

O'Connell, R. J., S4.120

O'Donnell, K., S4.162

O'Gorman, D. T., S4.124

Oh, Y., S4.41, S4.87

Ohtani, K., 741

Oil palm. See Elaeis guineensis

Oilseed rape. See Brassica napa

Ojiambo, P., S4.86

Ojiambo, P. S., 498, S4.161, S4.163

Okada, K., 674

Okada, R., S4.126

O'Keeffe, T. L., S4.89

Okubara, P., S4.109, S6.8

Okubara, P. A., 14, S6.10

Olatinwo, R., S4.87

Olaya, G., S4.88

Olea europaea (olive)

Colletotrichum spp. on

effect of temperature, wetness duration, and planting density on, 974

mummified fruit as source of inoculum, 982

Pseudomonas savastanoi on, film-forming polymers for management of, S4.39

Oleander. See Nerium oleander

Olfactory cues, manipulation of by vector-borne

pathogens, S4.150

Olive. See Olea europaea

Oliveira, M., S4.107

Oliver, J. E., S4.88

Olmstead, J. W., S4.17
Olson, S., S4.89

Omarov, R. T., S4.81

OmpA, Xanthomonas albilineans on sugarcane and, S4.39

Oncidium spp., identification and characterization of soft-rot pathogens isolated from, S4.19

Önelge, N., 1168

ONI. See Oceanic Niño index

Onion. See Allium cepa

Onion ipmPIPE project, overview of, S4.107

Onion thrips. See Thrips tabaci

Ophiognomonia clavigignenti-juglandacearum, on

butternut

effect on genetic diversity of regenerating populations, S4.13

inhibition in vitro by fungi associated with butternut, Japanese walnut, and hybrid butternut, S4.57

Ophiosphaerella korrae, on bermudagrass, S4.39

Opiyo, S. O., S5.3

Orchids, identification and characterization of soft-rot

pathogens isolated from, S4.19

Ordinal qualitative data, rank regression for

analyzing for treatment comparison, 1064

Organic farming

assessing growers' beliefs regarding soilborne disease management, S4.10

expert perspective on grower decision-making process related to soilborne disease management, S4.10

Helminthosporium solani and Colletotrichum coccodes on potato and, S4.77

of lettuce, diseases observed in high tunnel and open field organic production, S6.11

management of Xanthomonas euvesicatoria on tomato and, S4.31

natural products for suppression of cucumber damping-off pathogens, S4.100

Pseudoperonospora cubensis on cucumber, control with biopesticides, S1.5

Pythium ultimum and Rhizoctonia solani on cucumber and, S3.4

soil RNA analysis of soil microbes in, S4.46

of tomatoes, impact of mixed-species cover crops on rhizosphere pathogens of, S4.115

Oropeza, C., S6.2

Orquera, G., S4.89

Orquera, G. K., S4.43

Orshinsky, A. M., S1.1

Ortega-Beltran, A., S4.89

Ortiz, C. S., S6.4

Oryza sativa (rice)

AvrPiz-t suppresses host innate immunity by targeting the RING finger E3 ligases APIP6 and APIP10 in, S4.165

Burkholderia spp. on genomic island-based plasticity among genomes of, S4.41

B. glumae on: comparative genomic analysis of, S2.4; genetic and phenotypic variations among strains, S2.6; genetic dissection of regulatory network controlling virulence, S2.5; global regulatory network for virulence of, S4.148; naturally occurring avirulent strains, S4.62; non-thermal plasma seed treatment for control of, S6.1; quantification of yield losses caused by, S4.144; regulation of the virulence factors by the TofI/TofR quorum-sensing system, S2.2; tofM and quorum-sensing independent biosynthesis of toxoflavin, S4.22

Cercospora janseana on

effect of planting date, fungicide timing, and varietal susceptibility levels, S4.75

planting date, fungicide timing, varietal tolerance and, S2.6

Cochliobolus miyabeanus on, predisposition

factors affecting disease development in, S4.74

draft genomic sequence of pathogens and

nonpathogens of, S4.158
Gibberella fujikuroi on, non-thermal plasma seed treatment for control of, S6.1

Magnaporthe oryzae on

disease reactions of IRRI near-isogenic rice to U.S. isolates, S4.37

effector proteins and delivery into living cells, S4.165

ianjingyeshengdao cultivar, mapping resistance genes of, 779

identification of $P i b$ gene in National Small

Grains Collection and, 700

methods for identifying and quantifying partial resistance, $\mathrm{S} 4.135$

nep1-like fungal toxin targets a conserved ubiquitin-like protein and necrotic cell death, S4.131

Neovossia horrida on, field evaluation of

fungicides for control of, S4.144

Rhizoctonia solani on

AG-1 IA, in Colombia, S4.97

brassica biofumigation cover crop and plant growth-promoting rhizobacteria for control of, S4.144

in fields undergoing rotation with soybean, S4.113

QoI resistance and, S4.88

screening for biofumigants for, S6.2

strategic, statistical, prescriptive model for

disease prevention in, $\mathrm{S} 4.113$

Ustilaginoidea virens on

effective management strategies for, S2.6

field evaluation of fungicides for control of, S4.144

Xanthomonas oryzae on

pv. oryzae, Xa33 gene and resistance, 222

pv. oryzicola: $h \operatorname{sh} B$ gene, quorum sensing, $c l p$ and, 252; regulation of $e p v$ by DSFmediated quorum sensing and, 841 ; variable number of tandem repeats typing scheme for, 948

TAL effectors and virulence, $\mathrm{S} 4.127$

Osborne, L., 652

Osborne, L. E., S4.61, S5.2, S5.5

Osterbauer, N., S4.89

Ostrofsky, W. D., S4.84

Ostry, M., S4.57

Ota, Y., S4.63

Otrosina, W. J., S4.129

Ott, O., 1016

Otto-Hansen, L. K., S4.6

Oudemans, P. V., S1.8, S4.93

Outwater, C. A., S5.8

Ownley, B., S4.14

Ownley, B. H., S2.3, S4.36

Oxalic acid, Sclerotinia sclerotiorum on peanut and,

S6.10

Oxidative stress response, Pantoea stewartii subsp. stewartii on corn and, S4.17

Oxytetracycline, for Pseudomonas syringae patho-

vars on sweet cherry, S4.2

Özakman, Y., S4.89

Ozias-Akins, P., S2.4

Ozkan, E., S4.144

Ozone treatment, for elimination of Clavibacter michiganensis subsp. michiganensis from greenhouse surfaces, S5.10

P, S., S4.126

Padgett, G., S4.3

Padlock probes (PLP), for identification of Phytophthora spp., 635

Paecilomyces lilacinus, for control of pale cyst nematode, S4.137

Paenibacillus sp., on oil palm, in Peru, S4.118

Paetzold, L., 1079

Pallas, V., 1108

Palm, date. See Phoenix dactylifera

Palm, M. E., S4.16

Palm, oil. See Elaeis guineensis 
PALM1, wax metabolism fungal pathogen spore differentiation and, S4.124

Palmateer, A. J., S4.19, S6.4, S6.5

Palmer, A., S4.25

Palmer, C., S1.6

Palmer, C. L., S4.125

Palmer, M. W., 166

Palumbo, J. D., S4.89

PAMP. See Pathogen-associated molecular patterns (PAMP)

Pan, Q., S4.142

pANA1 plasmid, of Pantoea ananatis, comparative genomic and biochemical analyses of the, S4.29

Pandey, M. K., S4.71

Panicum virgatum (switchgrass)

diseases of in Mississippi, S4.45

DNA barcodes for identification of rust populations on, S4.89

impact of fungicides on rust intensity and biomass yield, S4.14

pathogenicity and virulence of Bipolaris spp. on, S4.36

Puccinia emaculata on, S4.124, S4.157

Panthi, A., S4.134

Pantoea spp.

acquisition and transmission of by onion thrips, S4.33

P. agglomerans

on cotton, transmission of by Nezara viridula, S4.79

on gysophila, polar auxin transport and gall

formation, S4.20

on onion, in Pennsylvania, S4.92

P. ananatis

comparative genomic and biochemical analyses of the large pPANA1 plasmid of, S4.29

functional characterization of quorum sensing in, S4.109

on maize, in Mexico, S6.6

type VI secretion system in, bacterial competition and, S4.109

$P$. stewartii subsp. stewartii, on corn, regulation

of oxidative stress response in, S4.17

Papaya. See Carica papaya

Papaya root spot virus, breeding papaya for resistance to, $\mathrm{S} 4.129$

Pappu, H., S4.113, S4.121, S6.8

Pappu, H. R., S4.3, S4.8

Parajuli, K., S4.10

Parameswaran, L., S4.15

Parassa vitidissima (nettle caterpillar), on oil palm, S4.87

Paret, M., S4.78, S4.89

Paret, M. L., 105

Park, B., S4.162

Park, C., S4.165

Park, S., S4.115

Park, S. Y., S6.3

Parker, J. K., S4.90

Parker, J. Parker, J., S2.10

Parker, P. E., S4.13

Parkunan, V., S4.30, S4.90

Parnell, S. R., S4.161

Parra, J., S6.4

Partial resistance, minor gene-for-minor gene

interaction explaining, 1086

Pase, H. A., S4.78

Paspalum vaginatum (seashore paspalum), Phyllachora paspalicola on, S4.76

Passiflora edulis (passion fruit), Cucumber mosaic

virus in, in Korea, S4.63

Passion fruit. See Passiflora edulis

Pastalka, T., S4.90

Pastor-Corrales, M., S4.90, S4.126

Patel, J. S., S4.91

Patel, N., S4.90

Pathogen-associated molecular patterns (PAMP), eicosapolyenoic acid in Arabidopsis and tomato, S4.100
Pathogenesis-related protein 1 (PR-1) family

Puccinia graminis f. sp. tritici on wheat and, S4.73

of wheat, heterologous expression and functional analysis of, S4.33

Patterson, C. D., 575

Paul, N. C., S4.142

Paul, P., 306, S4.32, S5.7

Paul, P. A., 55, 177, 867, S4.5, S4.21, S4.28, S4.65, S4.82, S4.105, S4.135, S5.8

Paulitz, T., S4.8

Paulitz, T. C., S4.141

Pauls, K. P., 434

Paveley, N. D., S4.53, S4.54

Payton, M., S4.44

PBNSPaV. See Plum bark necrosis stem pitting

associated virus

PCN (potato cyst nematodes). See Globodera pallida

PCR. See also Real-time PCR

application of primer and probe modifications in detection, biosecurity, and microbial forensics, S4.6

for Bean pod mottle virus, S4.20

for Blackberry chlorotic ringspot virus (BCRV),

Strawberry necrotic shock virus (SNSV) and

Tobacco streak virus (TSV), S4.53

for Botrytis cinerea on grapevine, S4.104

for Candidatus Liberibacter solanacearum on potato and psyllids, LAMP assays vs., 899

for detection and discrimination of Maize dwarf mosaic virus, Sugarcane mosaic virus, and

Sorghum mosaic virus, S4.89

for fungi causing soybean diseases, S4.51

for Huanglongbing in citrus and non-citrus hosts, $\mathrm{S} 4.55$

padlock probe-based microarray for Phytophthora spp., 635

for Phacidiopycnis washingtonensis and Sphaeropsis pyriputrescens on apple, S4.109

for Pseudomonas viridiflava on apple, S4.117

for the specific and rapid identification of Bemisia tabaci and Trialeurodes vaporariorum, $\mathrm{S} 4.5$

for sRNAs in Xylella fastidiosa, S4.22

for Verticillium dahliae in soil, 331

for viruses in grapevine, $\mathrm{S} 4.82$

Pea. See Pisum sativum

Peach. See Prunus persica

Peach latent mosaic viroid (PLMVd), multiplex

TaqMan real-time RT-PCR assay for detection of, S4.71

Peach replant disease. See Prunus replant disease

Peanut. See Arachis hypogaea

Pear. See Pyrus spp.

Pearce, C., S4.106

Pearsaul, D., S4.88

Pearson, L. M., S4.163

Pecan. See Carya illinoensis

Pectin methylesterase, Moniliophthora perniciosa on cacao and, S4.88

Pectobacterium spp.

$P$. carotovorum

on onion, in Pennsylvania, S4.92

regulation of expression of corA, a virulence factor and magnesium, nickel, and cobalt transporter in, $\mathrm{S} 4.32$

on potato, coinfection with Verticillium dahliae and, S4.32

species associated with bacterial stem rot syndrome of potato in Canada, 937

Pedersen, D. K., S4.21

Pedersen, J. F., S4.157

Pedley, K. F., S5.3

Pedrini, J., S4.101

Pedrozo, R., S4.91

Peduto, F., S4.91

Peeden, K., S4.72

Peever, T., S5.5

Peever, T. L., 741

Pegues, M., S4.49

Pekhtereva, E., S4.64
Pelican, T., S4.60

Pelletier, Y., S4.149

pemI/pemK toxin-antitoxin (TA) system, inheritance

of pXF-RIV11 in Xylella fastidiosa and, 32

PEN1, innate immunity and, S4.116

Peng, G., S4.46

Peng, K.-C., 1054

Pengue, G., S5.9

Penicillium spp.

on apple

new species on stored fruit, S4.92

sensitivity of isolates from decayed fruit to postharvest fungicides, S4.43

P. expansum

on apple: bin-top sprays for controlling, S1.7; Lamiaceae essential oils for control of, S4.112; organic chlorine for control of $\mathrm{S} 4.125$; pyrimethanil resistance in, $\mathrm{S} 4.18$ microscope slide (MSMA) assay for monitoring, S4.125

fitness and competitiveness of isolates with reduced sensitivity to fludioxonil and pyrimethanil, S6.9

on pome fruit in storage, $\mathrm{S} 4.43$

on tomato, in British Columbia, S6.11

Pentalonia nigronervosa

Banana bunchy top virus and, rt-PCR and immunofluorescence assays for, S4.16

Buchnera GroEL from, interaction with Banana bunchy top virus and, S4.132

Pentaplex Q-PCR, for fungi causing soybean

diseases, S4.51

Penthiopyrad

for Cercospora arachidicola on peanut, penthiopyrad and pyraclostrobin for, S2.2

for control of Rhizoctonia solani on sugar beet, S5.6

Pepino mosaic virus (PepMV)

attenuated strain effective for cross protection, S5.3

in tomato, shift in North America to Chilean genotypes of, S4.71

PepMV. See Pepino mosaic virus

Pepper. See Capsicum annuum

Peptidoglycan, activation of innate immune response in plants and, S4.35

Peralta, C., S4.91

Peralta-Nava, J. A., S6.6

Perecin, D., S4.38

Pereira, R., 490

Peres, N., S4.53

Peres, N. A., S4.4, S4.7, S4.40, S4.46, S4.80, S4.107

Peres, N. N., S4.4

Perez, J., S4.110

Perilla, L., S4.41

Perkins, R., S2.11

Pernezny, K., S2.3

Peronosclerospora spp., on sugarcane, repeating struc-

ture of internal transcribed spacer region 2 in, S4.73

Peronospora spp.

$P$. belbahrii, on basil

evaluating fungicides for control of, $\mathrm{S} 1.3$

peroxidase, total phenolics, and host resistance, $\mathrm{S} 4.79$

P. farinosa, on spinach, overview of resistance, S4.26

P. parasitica, on Camelina sativa, $\mathrm{S} 4.114$

P. sparsa, on blackberry, S4.15

$P$. variabilis, on quinoa, S1.7, S4.118

Peroxidases

in jalapeño pepper with Streptomyces spp., S4.46

localization of in birch infected with Inonotus obliquus, S4.141

resistance of basil against Peronospora belbahrii and, S4.79

Perry, K. L., S4.49, S4.65, S4.92, S4.155

Persea americana (avocado)

branch canker of, fungicides for management of S4.123 
Fusarium sp. on in California, Asian ambrosia beetle and, $\mathrm{S} 4.35$

Persicaria perfoliata (mile-a-minute), Colletotrichum gloeosporioides for control of, S3.1

Pesole, G., S4.120

Pesticides

electronic nose technology for residue detection, S4.136

smart spray systems to enhance delivery of, S4.144

Peter, K. A., S4.43, S4.58, S4.92, S4.127

Peterka, H., S4.136

Peters, J., S4.135

Peters, R. D., S1.5, S4.62, S4.92

Peterson, G. L., S4.73, S5.3

Pethybridge, S. J., S4.92, S4.125

Pfaff, M., S4.112

Pfender, W. F., S4.52

Pfeufer, E. E., 272, S1.7, S4.92

PG. See Polygalacturonidase

Phacidiopycnis washingtonensis, on apple, PCR assays for, S4.109

Phaeocryptopus gaeumannii, on Douglas fir, effec-

tiveness of disease management program in Pacific

Northwest, S6.8

Phaeomoniella chlamydospora, on grape

in Chile, S4.29

colonization of fluorescent, 290

Phage $\phi R S M$ and $\phi R S S 1$, virulence of Ralstonia solanacearum on tomato and, 469

Phakopsora pachyrhizi

detection of from multigenomic samples, S4.35

on kudzu, epidemiology of, S2.11

on soybean

effects of daily temperature highs on development of, 761

effects of dew-period temperature changes on initiation of infection, S4.13

epidemiology of, S2.11

evaluation of recombinant inbred line (RIL)

derived sister lines for resistance to, $\mathrm{S} 2.4$

fungicide sensitivity and timing of application and, S4.122

multiplexed immunofluorescence method for identification and viability determination, $1143, \mathrm{~S} 4.128$

new resistance gene in PI 567102B, S4.68

proteomics study of host-fungus interaction, S4.150

Simplicillium lanosoniveum for control of, 749

solar radiation and infection severity, 794

temporal dynamics of, leaf area index and, S4.82

variability of the internal transcribed spacer region within, $\mathrm{S} 4.103$

Phalaenopsis spp., identification and characterization

of soft-rot pathogens isolated from, S4.19

Phaseolus spp.

P. lunatus (lima bean), Phytophthora capsici,

evaluation of germplasm for resistance, S4.36

$P$. vulgaris (bean)

Bean common mosaic virus in: characterization of two field isolates of, S4.93; genome sequences of two isolates, S6.9

Bean golden mosaic virus in, epidemiology in transgenic lines, S4.37

Colletotrichum lindemuthianum on, phenotypic variability in populations, 490 endornaviruses in germplasm, S4.126

Pseudomonas syringae pv. syringae on: alkyl dimethyl ammonium chloride for control of S4.122; salA, syrF, and syrG regulatory networks involved in pathogenesis of, S4.126 reproduction of soybean cyst nematode on accessions of core collection, S4.93

Sclerotinia sclerotiorum on, in upper Egypt, $\mathrm{S} 2.1$

Uromyces appendiculatus on, genetic analysis of broad-spectrum resistance, $\mathrm{S} 4.90$
Xanthomonas campestris on, image analysis and studies of quantitative disease resistance, 434

Phellinus sp., on ironwood, S4.106

Phenacoccus aceris (mealybug), transmission of six ampeloviruses and two vitiviruses to grapevine by 717

Phenazine

biosynthesis by Pseudomonas chlororaphis strain 30-84, differential regulation of by RpeA and RpeB in, S4.130

role of structural derivatives in fungal inhibition and biofilm formation, $\mathrm{S} 4.141$

Phenolic compounds

Botryosphaeria spp. growth and laccase and, S4.113

resistance of basil against Peronospora belbahrii and, S4.79

resistance to Diplodia pinea and, S5.9

Phialocephala fortinii s.l. - Acephala applanata

species complex (PAC), ectomycorrhiza on conifer seedlings colonized by dark septate endophytes and, S4.98

Pho P/Q-regulated genes, Salmonella enterica root

colonization and, S4.50

Phoenix spp. (palms)

fungal diseases of, in California, S6.12

sequencing of transcripts in response to salt stress, S4.96

Phoma spp.

P. exigua var. exigua, on chicory root, $\mathrm{S} 4.41$

$P$. ligulicola, on pyrethrum, taxonomic reassessment of, S4.125

P. medicaginis, on alfalfa characterization of mutant forming hyaline pycnidia, S4.24

poly(A) RNA polymerase gene disruption and, S4.24

on sugar beet, variability in, S4.50

Phomopsis spp.

$P$. amygdali, on Japanese andromeda, in United

States, S4.11

P. longicolla, genetic transformation system for, S4.99

P. vaccinii, on cranberry, $\mathrm{S} 4.19$

PhoP/Q two-component regulatory system, Xylella

fastidiosa on grape and, S6.11

Photocatalysis, for control of Xanthomonas perforans on tomato, S4.89

Phragmidium violaceum, on non-native Rubus spp., S3.2

Phyllachora spp.

molecular phylogeny within, S4.105 on seashore paspalum, S4.76

Phyllocoptes fructiphilus, rose rosette and, S2.7

Phymatotrichopsis omnivora, on cotton, flutriafol for management of, S4.57

Physalis peruviana (cape gooseberry), plant growth regulators produced by rhizobacteria, $\mathrm{S} 4.112$

Phytochelatin synthase, Erwinia amylovora virulence and, S4.79

Phytohormones, for suppression of clubroot in Arabidopsis thaliana and Brassica oleracea, S4.72

Phytopathology, poetry of, S4.121

Phytophthora cactorum, on strawberry, cultivar resistance and chemical and cultural control, S4.107

Phytophthora spp.

on almond and stone fruits, resistance in new rootstocks, S4.106

CANARY technology for rapid detection of, S4.15

P. capsici

on chili pepper: effect of two inoculants on,

S6.12; screening for biocontrol agents for, $\mathrm{S} 4.50$

induced resistance in chile pepper following inoculation with nonhost Phytophthora nicotianae, S4.114

on lima bean, evaluation of germplasm for resistance, $\mathrm{S} 4.36$ monitoring changes in population structure of isolated research population of, $\mathrm{S} 4.32$

on pepper: correlation of host resistance with fruit traits, S4.85; in southern France, S2.5 on squash, Bacillus subtilis IN937b and host plant defense induction, S4.81

on tomato: early infection, salt stress of roots and, S4.95, S6.12; SAR inducers, chitosan, and silicon for control of, S4.80

variation within isolates from worldwide collection, $\mathrm{S} 4.47$

in vitro and in vivo RNAi silencing of, S4.114

P. cinnamomi

mitochondrial haplotype analysis for differentiation of isolates, 229

on rhododendrons, flooding stress and, S4.65 on white oak, in northeastern United States, S4.78

P. colocasiae, on taro

population structure using SNP markers, S4.109

SNP markers for, S2.9

P. cryptogea, on chicory root, S4.41

diversity in Pennsylvania forest streams, S4.64

estimation of phylogeny using multilocus analysis of mitochondrial genes, S4.76

ethaboxam seed treatment for

amended agar and greenhouse assays for, $\mathrm{S} 4.31$ efficacy of, S4.31

hybridization and new pathogens, S4.160

$P$. infestans

analysis of mitochondrial haplotypes and correlation with nuclear genotype, S4.76

characterization of lineages in U.S. using microsatellite markers, S4.110

CRT1 gene and plant immunity, S4.75

fungicide resistance, EST analysis for candidate genes involved in, S4.20

mefenoxam sensitivity of recent strains in

United States, S4.84

new sensu lato population in Colombia, S4.80

oospore formation in potato, tomato, and solanaceous weeds, S4.44

phenotypic and genotypic characterization of recent clonal lineages in U.S. and Canada, S4.28

phylogeographical analysis of dynamics of evolution in, S4.117

on potato: Alternaria grandis and, comparative epidemiology in Brazil, S4.32; genotype distribution in Canada in 2011, S4.62; molecular determinants of resistance activation and suppression by effector IPI-O, S4.22; phenotypic variation within a clonal lineage in Nicaragua, 323; potassium phosphite and, S1.5; tuber and foliage transcriptome dynamics, S4.42; USABlight and fungicide sensitivity of recent isolates, S4.106; weed hosts and aggressiveness of, 429

on tomato: assessing fitness of new clonal lineages by comparing sporangial production, S5.9; genotype distribution in Canada in 2011, S4.62; phenotypic variation within a clonal lineage in Nicaragua, 323; transmission by seedlings but not seed, $\mathrm{S} 4.78$ weed hosts of, S4.107

zoospore lysis in sporangial suspensions made from, $\mathrm{S} 4.10$

in irrigation water, risks to ornamental nursery plants and, S4.73

mechanisms of pathogen emergence, $\mathrm{S} 4.48$

P. nicotianae

on citrus, volatile compounds produced by saprophytic fungi and, S4.99

induced resistance in chile pepper against Phytophthora capsici following inoculation with, S4.114

overview of, 348 
P. parasitica var. nicotianae, on tobacco, rapid microbioassay for discovery of antagonistic bacteria for, 267

population change in two streams over one-year period, S4.9

P. ramorum

on coast live oak, metabolite profiling to predict resistance, $\mathrm{S} 5.3$

monitoring a sentinel plant system at the National Ornamentals Research Site at Dominican University of California, S4.90 overview of risks and research challenges for northeastern North America, S1.5

on red oak and balsam fir, S1.8

on rhododendron, abiotic stress, root infection, symptom expression, and chemical management, S4.103

from soil, steam disinfection of, S4.59, S4.60 stream baiting for, S2.1, S4.94

P. sojae

on soybean: combining isolates to screen for novel sources of resistance to, S4.77; evaluation of commercial cultivars for pathogen and pest resistance, $\mathrm{S} 4.21$; identification and comparison of quantitative trait loci conferring partial resistance to, S5.6; identification of QTL for partial resistance to, S4.1; increase in virulence and pathotype number in Minnesota since 1984, S5.1; race-specific resistance $R p s 3 \mathrm{a}$ and $R p s 8$ to, S5.5

staghorn sumac extracts for control of, S5.1 survival in sediments, S4.140

universal microarray detection method for using padlock probes, 635

Phytoplasmas

detection in Cicadellidae morphotypes in Colombia, S4.41

in grape, multilocus molecular genetic characterization of phytoplasmas affecting commercial vineyard, S3.2

$i$ PhyClassifier II for identification and classification of, S4.143

Phytotoxins

Fusarium virguliforme on soybean and, S4.139

Mycosphaerella fijiensis polyketide synthase genes and, S4.86

Pi2-1 gene, resistance against Magnaporthe oryzae on rice and, 779

Pi51(t) gene, resistance against Magnaporthe oryzae on rice and, 779

Pib gene, resistance of rice against Magnaporthe oryzae, in National Small Grains Collection, 700

Picha, D. H., S2.10

Picton, D. D., S4.24, S4.103

Piepho, H., S4.110

Piepho, H.-P., 381

Pierce, B. K., S6.11

Pieris japonica (Japanese andromeda), Phomopsis amygdali on, in United States, S4.11

Pierson, E., 899

Pierson, E. A., S4.130, S4.141, S6.4

Pierson, L. S., S4.141

Pierson, L. S., III, S4.130

Pierson, T. J., S4.28

Pieterse, C. M. J., 403

Pik-h, Magnaporthe oryzae on rice, resistance and, S4.142

Pilidium concavum, on Japanese knotweed, S4.16

Pilkington, S., S4.92

Pine. See Pinus spp., Dothistroma spp. on, in France, 47

Pine, loblolly. See Pinus taeda

Pinto, D. H., S1.5

Pinto, J. M. A., 490

Pintye, A., 707

Pinus spp.

P. elliotii, Leptographium spp. on, variation in family resistance to, $\mathrm{S} 2.9$ normal destruction of cortical tissue in roots,

S4.129

$P$. radiata (Monterey pine)

Fusarium circinatum on: induced resistance in seedlings, S4.116, S6.13; predicting disease populations over time, S4.99

P. strobus (white pine)

Cronartium ribicola on, proteomic study of interaction, S6.10

white pine needle damage in, S4.84

$P$. taeda (loblolly pine)

Leptographium spp. on, variation in family resistance to, $\mathrm{S} 2.9$

mapping extent of Pine Decline in Alabama and Georgia, S2.8

potential pyrophilous fungus following a

forest fire and, S4.78

thinning and Pine decline in, S2.11

Piou, D., 47

Piperidine alkaloids, Pythium ultimum on cucumber and, S4.68

PIPs. See Plant-incorporated protectants

Pisum sativum (pea)

Aphanomyces euteiches on, normalized changes

in gene expression in response to infection,

S4.104

evaluating selected varieties for resistance to root pathogens, S1.1

Pithomyces chartarum, on Miscanthus $\times$ giganteus,

screening for fungicide control and, S4.2

Pityophthorus juglandis. See also Thousand cankers

disease

isolation of Geosmithia morbida from, S4.128

life history and association with Geosmithia morbida, $\mathrm{S} 4.159$

Planchamp, C., S4.92

Plant growth regulators, Sclerotinia homoeocarpa on turfgrasses, fungicide efficacy and, S4.56

Plant Virus Biodiversity and Ecology, identification of Ambrosia asymptomatic virus 1 by, $\mathrm{S} 4.33$

Plantain. See Musa spp.

Plant-incorporated protectants (PIPs), regulation of, S4.154

Plasmodiophora brassicae (clubroot)

in Arabidopsis thaliana and Brassica oleracea, salicylic acid suppression of, S4.72

in Brassica spp. comparison of host resistance and, S4.78 salicylic acid suppression of, S4.72

changes in ROS and lignin associated with progression from cortical to stele cells, S4.29

effect of soil type and compaction on severity of, S4.46

reaction of lines of Arabidopsis and the Rapid Cycling Brassica Collection to Canadian pathotypes of, S4.108

Plasmopara spp.

$P$. halstedii, in sunflower seeds, optimized duplex real-time PCR assay for detection of, 908

P. obducens, on impatiens, in Florida, S6.4

$P$. viticola, on grape

G143A mutation and resistance to stroliburinclass fungicide, $\mathrm{S} 4.23$

mode of host resistance to, 1094

rain and dispersal of primary inoculum of 158

Plasticity. See Genome plasticity

Plastoquinone partitioning, apple disease resistance and, S4.110

Plata R., G., S4.118

Platt, H. W., S4.62

Plectosphaerella cucumerina, for control of pale cyst nematode, S4.137

Plectosporium tabacinum, on lettuce, cilantro, and chervil, S4.125

Plewa, D., S5.9

Pliansinchai, U., S4.76

PLMVd. See Peach latent mosaic viroid

Plot size, accuracy of field trial data and, S4.152
PLP. See Padlock probes

Plum. See Prunus spp.

Plum bark necrosis stem pitting-associated virus

(PBNSPaV), multiplex TaqMan real-time RT-PCR assay for detection of, S4.71

Plum pox virus (PPV)

detection by recombinase polymerase amplification, S4.143

EDNA assay for, S4.115

National Clean Plant Network and, S4.154

Poa spp.

P. annua (annual bluegrass), Colletotrichum cereale on

mechanical injury and disease severity, S1.3

nitrogen fertilization and, S1.7

temperature and appressorium formation,

S4.132

P. pratensis (Kentucky bluegrass), Claviceps purpurea on, preconditioning cold treatments and incubation temperature and, S4.123

Podosphaera spp.

$P$. aphanis, on strawberry early-season cryptic development, S4.7 temperature as repressor of ascocarp formation, S4.7

$P$. clandestina, on cherry, in Washington state, S4.72

P. macularis, on hop characterization of ontogenic resistance, S4.137

mating type distribution in Pacific Northwest, S4.137

P. xanthii

on cucumber, suppression by UV-B, S4.116

on muskmelon, resistant cultivars, S1.6

Poe, P., S6.13

Poetry of phytopathology, S4.121

Poghosyan, A., S6.5

Poinsettia spp., multilocus sequence analysis of

xanthomonads associated with, S4.101

Pokharel, R., S4.93

Poland, J., 1016

Polashock, J., S4.8, S4.93

Polashock, J. J., S1.8

Poleatewich, A., S4.93, S5.10

Poly(A) RNA polymerase gene, Phoma medicaginis morphology and, S4.24

Polygalacturonidase (PG), constitutive plasmid-based expression in Xylella fastidiosa, S6.13

Polyketide synthase genes, Mycosphaerella fijiensis phytotoxin production and, S4.86

Polymer coatings. See Biopolymer coatings

Polyol pathway, Fusarium verticillioides SDA1 and, S6.1

Polyphenol oxidases, in jalapeño pepper with Streptomyces spp., S4.46

Polyubiquitin, Magnaporthe oryzae growth, devel-

opment, and pathogenicity and, S4.87

Pomegranate. See Punica granatum

Poorten, T. J., S4.162

Popko, J., S1.4

Popko, J. T., S4.56, S4.105

Poplawsky, A., S4.93

Poplawsky, A. R., S6.9

Populus spp.

culturable microbes from different organs of,

S4.69

induced systemic defense responses to pathogens and wounding in two clones of, S4.40

recent mortality and climate in North America, S4.137

Poromarto, S. H., S4.93

Porto, H., S4.32

Posey, S., S4.43

Pospiviroids, detection in greenhouse and field crops,

S4.47

Postman, J. D., S4.100

Potassium phosphite, Phytophthora infestans on potato and, S1.5 
Potassium phosphonate, for Sphaerotheca fusca on watermelon, S4.61

Potato. See Solanum spp.

Potato cyst nematodes (PCN). See Globodera pallida

Potato psyllid. See Bactericera cockerelli

Potato virus $H$ (PVH), in potato, in China, S4.69

Potato virus $Y$ (PVY)

antigenic structure of, S4.62

in Canada, S4.149

classification of strains and new recombinants, S4.149

outbreak of strain PVYNTN in foundation seed

potatoes in Japan, S4.23

in potato

breeding for resistance, $\mathrm{S} 4.148$

as emerging problem in North America,

S4.148

modeling aphid vector flights and, S4.148

predominance of Agata cultivar and, S4.97

as threat to other solanaceous crops, S1.4

seed certification and, S4.149

Syrian isolate overcoming resistance genes but

inducing hypersensitive reaction, S4.23

Potere, O., 1168

Potnis, N., S4.45, S4.94, S4.148

Poulin, L., 948

Poussier, S., 733

Poveda, F. P., S4.94

Powdery mildew, on strawberry, evaluation of

epidemiology and prediction tools of, S4.17

Powell, C. A., 567, S4.143, S4.144

Powell, M., S6.11

Power, I. L., S2.8, S4.151

Powers, T. O., S5.2

Pozza, A. A., S4.27

Pozza, E. A., S4.27

PPV. See Plum pox virus

PR-1 proteins. See Pathogenesis-related protein 1 (PR-1) family

Prasongsuk, S., S4.105

Pratylenchus sp. (root-lesion nematode)

on corn, two methods for extraction from roots, S4.9

P. penetrans, on potato, 519

commercial-scale soil test data and, S4.45 manipulating inoculum densities with green manure amendments and solarization, 519

P. thornei, detection and quantification in DNA extracted from soil, 14

Premature vine decline, in tomato, chemical and

biological control of, S4.74

Prestige, of scientists, S4.166

Preston, J. F., S4.108

Price, J. A., S4.94

Pringle, H., S4.133

Pritchardia pacifica, Texas Phoenix palm decline on, transmission by Haplaxius crudus, S6.2

Prithiviraj, B., S3.2

Proffer, T. J., S5.8

Programmed cell death (PCD), Trichoderma

harzianum ETS 323 and Botrytis cinerea and, 1054

Progress stairs. See Area under the disease progress stairs

Prom, L. K., S4.157

Propiconazole

ABC transporter gene from Sclerotinia homoeocarpa and, S4.105

for Monilinia vaccinii-corymbosi on blueberry, resistance to, $\mathrm{S} 4.119$

for Sclerotinia homoeocarpa, overexpression of BcatrD homolog from resistant strains, S1.4

Sclerotinia homoeocarpa and, overexpression of ShCYP51B and ShatrD in resistant strains and, $\mathrm{S} 4.56$

Prospero, S., 73

Proteomics analysis

of Cronartium ribicola on white pine, S6.10 of Phakopsora pachyrhizi-soybean interaction, S4.150 for virus-vector interface, S4.164

PRSV. See Papaya root spot virus

Prunus replant disease

first year almond tree performance, preplant soil steam, backhoe, and fumigation treatments in a replanted site with the presence of plant-parasitic nematodes, $\mathrm{S} 4.31$

growth of new rootstocks and, S4.16

trenching, rootstock, and compost for management of, S4.93

Prunus spp.

P. armeniaca (apricot), Cherry twisted leaf

associated virus in, $\mathrm{S} 4.128$

P. avium (sweet cherry)

Armillaria mellea on, iodomethane for control of, S6.10

Blumeriella jaapii on, in Tennessee, S4.60

Cherry twisted leaf associated virus in, S4.128

Podosphaera clandestina on, in Washington state, S4.72

Pseudomonas syringae pathovars on, new treatments for, $\mathrm{S} 4.2$

P. cerasus (tart cherry), Blumeriella jaapii on boscalid resistance and, S5.8 effects on photosynthesis in foliage, 656

$P$. domestica (plum), screening for resident bacterial with biocontrol activity against Monilinia fructicola, $\mathrm{S} 4.58$

P. dulcis (almond)

Phytophthora spp. on, resistance in new rootstocks, S4.106

preplant soil steam, backhoe, and fumigation treatments in a replanted site with the presence of plant-parasitic nematodes, S4.31

growth of new rootstocks for in fumigated and

non-fumigated replant soil, $\mathrm{S} 4.16$

ilarviruses of, 1108

$P$. persica (peach)

Armillaria mellea on, iodomethane for control of, S6.10

Fusicladium carpophilum on, sporulation model, S1.4

Monilinia fructicola on: fine-scale genetic structure of populations within tree canopies, S4.36; fruit surface chemistry and susceptibility to, S4.139; new mechanism of DMI fungicide resistance in, S2.2

prunus replant disease of, trenching, rootstock, and compost for management of, S4.93

P. persica var. nucipersica (nectarine), Fusicladium carpophilum on, sporulation of, relative humidity and temperature and, 421

Phytophthora spp. on, resistance in new rootstocks, S4.106

Pruss, G., S4.165

Pryor, B. M., 1130, S4.162

Pseudomonas spp.

$P$. aeruginosa

Mexican fruit fly and, S6.1

overexpressing $r s m A$ from, virulence of select phytotoxin-producing strains of $P$. syringae and, 575

P. chlororaphis, strain 30-84

differential regulation of phenazine biosynthesis by RpeA and RpeB in, S4.130

phenazine structural derivatives, fungal inhibition and biofilm formation and, S4.141

$P$. fluorescens

for control of pale cyst nematode, S4.137 defense gene induction in wheat and, S6.10

2,4-diacetylphloroglucinol from, and induced systemic resistance in Arabidopsis thaliana against Xanthomonas translucens pv. undulosa, 390

strain CL145A, in vitro activity against phytopathogenic microorganisms, S4.119
P. savastanoi

IS53 transposase promoter from, expression under heat shock, S4.20

on olive, film-forming polymers for management of, S4.39

P. sp. LBUM300, for control of Clavibacter

michiganensis subsp. michiganensis on tomato,

DAPG, HCN production and, 967

P. syringae

on Arabidopsis thaliana, compartment-specific antioxidative defense in, 662

on tomato, horizontal gene transfer and, S4.160

type III secretion system (T3SS) of, S4.165

virulence of select phytotoxin-producing strains of, overexpressing rsmA from Pseudomonas aeruginosa and, 575

on watermelon and squash, S4.103

P. syringae pv. actinidiae, on kiwifruit

anatomical changes in wood and primary infection sites, 827

phylogenetic relationships among global populations, 1034

population structure and possible origin of, S6.6

P. syringae pv. morsprunorum, on sweet cherry,

new treatments for, $\mathrm{S} 4.2$

$P$. syringae pv. syringae

on bean: alkyl dimethyl ammonium chloride for control of, S4.122; B728a, salA, syrF, and $\operatorname{syr} G$ regulatory networks involved in pathogenesis of, S4.126

on sweet cherry, new treatments for, S4.2

$P$. syringae pv. tomato

degree and rates of evolutionary change in, and impacts on forensic investigations, S4.58 induced systemic resistance in Arabidopsis thaliana against by 2,4-diacetylphloroglucinol-producing Pseudomonas fluorescens, 390

$P$. viridiflava

on apple, detection using specific designed primers, S4.117

on onion, S2.5

Pseudoperonospora cubensis

on cucumber aerial concentration and escape of sporangia, disease severity and, S4.86

organic, control with biopesticides, S1.5

on cucurbits, sporangia dynamics, population

structure, and fungicide efficacy, S5.4

Pseudotsuga sp. (Douglas fir), Phaeocryptopus gaeumannii on, effectiveness of disease management program in Pacific Northwest, S6.8

Psidium spp. (guava), Guignardia psidii on, effect of temperature on colonization, S4.25

PthA4, Xanthomonas citri subsp. citri on citrus and,

S4.55

Public policy, engagement in, S4.166

Puccinia spp.

$P$. arachidis, on peanut

characterization of resistance, $\mathrm{S} 4.151$

evaluation of ICRISAT varieties for resistance to, S2.4

resistance in new breeding lines, S2.8

P. emaculata

on Brachypodium distachyon, nonhost resistance, S4.123

on switchgrass, S4.124; DNA barcodes for identification of, S4.89; searching for sources of rust resistance and, S4.157

P. graminis

on oats, rye, and barberry, genetic variation in, 1006

on switchgrass, DNA barcodes for identification of, $\mathrm{S} 4.89$

P. graminis f. sp. tritici

Ug99 race group, rapid molecular assay for, S4.117 
on wheat: differential expression of the pathogenesis-related protein $1(P R-1)$ gene family and, S4.73; effect of temperature on latent period of isolates across different cultivars, S4.52; high-resolution mapping of Ug99 resistance gene from, $\mathrm{S} 4.145$

$P$. helianthi, on sunflower, race diversity in northern Great Plains in 2011, S4.42

$P$. hemerocallidis, on daylily, cultivar resistance to, S4.31

P. kuehnii, on sugarcane reaction of thirteen varieties, in Brazil, S4.82 resistant varieties in Brazil, S4.13

P. punctiformis, on Canada thistle, S3.1

$P$. striiformis

on barley, in United States in 2011, S4.130

on wheat: boosted regression trees to evaluate effect of drought indices and local weather conditions, in Kansas, S4.47; in United States in 2011, S4.130

P. striiformis f. sp. tritici

barberry is not alternate host for, in Pacific Northwest, S4.132

genetic characterization of virulence/avirulence genes of, S4.132

genetic diversity in international collections, S4.30

virulence and SSR markers reveal only asexual reproduction in U.S. pacific northwest population, S4.22

on wheat: managing in soft red winter wheat, S4.81; temperature shifts and resistance, S4.16

P. triticina

on wheat: Aegilops tauschii as a source of adult plant resistance to, $\mathrm{S} 4.61$; histological characterization of wheat pre-and posthaustorial resistance components, S5.4

Pueraria lobata (kudzu), Phakopsora pachyrhizi on, epidemiology of, S2.11

Pugliese, M., S4.94

Pumpkin. See Cucurbita pepo

Punica granatum (pomegranate), Neofusicoccum

mediterraneum, Diplodia mutila, and Diplodia

seriata on, $\mathrm{S} 4.83$

Punja, Z., S6.11

Punnapayak, H., S4.105

Puppala, N., S4.73, S6.10

Puri, K. D., S4.95

Purvis, M., S4.30, S4.90

Putman, A., S4.95

PVH. See Potato virus $H$

PVY. See Potato virus $Y$

Pye, M. F., S4.95, S4.100, S6.12

Pyraclostrobin

for Cercospora arachidicola on peanut, penthiopyrad and pyraclostrobin for, S2.2

concurrent, alternating, and mixture use of two

high risk fungicides as resistance management strategy and, S4.53

resistance to, in Botrytis cinerea on apple, 315 simulated rainfall to evaluate removal of, S4.46

Pyrenochaeta lycopersici, on tomato, secretion of

CDiT1 protein and, 878

Pyrenopeziza brassicae, on oilseed rape, reduced

azole sensitivity of, S4.19

Pyrenophora teres f. teres, on barley identification of multiple virulence QTL, S4.108 QTL mapping of effector-triggered sensitivity interaction, S4.72

in United States, S4.67

virulence profile and genetic structure of a North Dakota population of, 539

Pyrethrum. See Tanacetum cinerariifolium

Pyricularia oryzae, on wheat, biochemical changes in leaves, 1121

Pyrimethanil

fitness and competitiveness of Penicillium spp. isolates with reduced sensitivity to, S6.9 for Penicillium expansum on apple, resistance to, S4.18

Pyrus spp. (pear)

Erwinia amylovora on, acyl carrier protein and

virulence, S4.67

Gymnosporangium sabinae on, S1.4

Pythium spp.

P. aphanidermatum, on geraniums, Bradysia impatiens as vector of, 283

on carrot, multigene analysis of species, in California and Michigan, S4.102

$P$. dissotocum, on cilantro, detection of in hydroponic system, S6.5

diversity in Pennsylvania forest streams, S4.64

ethaboxam seed treatment for amended agar and greenhouse assays for, $\mathrm{S} 4.31$ efficacy of, S4.31

on peanut, effect of initial fungicide application timing and cultivar on, S2.10

in recycled irrigation water, influence on bacterial community in, $\mathrm{S} 1.2$

on soybean, in North Dakota, S4.145

species isolated from forest tree nursery soils in

Oregon and Washington, S4.43

species present in floricultural crops from Long

Island, New York, S4.43

stimulation of sexual structure production by,

S4.145

survival in sediments, $\mathrm{S} 4.140$

P. ultimum

on cucumber: natural products for suppression of, S4.100; piperidine alkaloids from fire and, S4.68

detection of from multigenomic samples, S4.35

on geraniums, Bradysia impatiens as vector of, 283

microbial-induced carbon competition in the spermosphere leads to pathogen and disease suppression in a municipal biosolids compost, 588

on organic cucumber, natural products for suppression of, S3.4

resolving species complex, S4.34

seed-colonizing bacterial communities associated with the suppression of seedling disease in a municipal biosolids compost, 478 on sugar beet, changes in bacterial communities after organic amendments to two soils and, 413

understanding impact on floricultural crops in North Carolina, S4.72

Q-bank database, for plant health diagnostics, S4.155 $q H S 2.09$, Sporisorium reiliana on maize and, molecular mapping with simple sequence repeat and single nucleotide polymorphism markers, 692

Qian, G., 252, 841

Qiu, D., S4.95

QoI fungicides. See Quinone outside inhibitor

fungicides

Q-PCR (quantitative PCR)

for Bean pod mottle virus, S4.20

for Blackberry chlorotic ringspot virus (BCRV),

Strawberry necrotic shock virus (SNSV) and

Tobacco streak virus (TSV), S4.53

for fungi causing soybean diseases, $\mathrm{S} 4.51$

QTL (quantitative trait loci)

for disease resistance in wheat and barley, 560

for partial resistance to Phytophthora sojae on soybean, S4.1

Pyrenophora teres f. teres on barley and effectortriggered immunity, S4.72

Pyrenophora teres $\mathrm{f}$. teres virulence on barley and, S4.108

$q H S 2.09$ for resistance against Sporisorium reiliana on maize, molecular mapping with simple sequence repeat and single nucleotide polymorphism markers for, 692 for resistance against Septoria passerinii on barley, 683

for resistance of maize against Stenocarpella maydis, $\mathrm{S} 4.102$

for resistance of soybean to Phytophthora sojae, S5.6

of rice for resistance to Magnaporthe oryzae, Pi2-1 and $P i 51(t)$ genes and, 779

Qu, F., 1176, S5.3, S5.6

Quercus spp. (oak)

Q. agrifolia (coast live oak)

Diplodia agrifolia on, $\mathrm{S} 4.74$

Phytophthora ramorum on, metabolite profiling to predict resistance, S5.3

Q. alba (white oak), Phytophthora cinnamomi on, in northeastern United States, S4.78

Phytophthora cinnamomi on, in northeastern United States, S4.78

Q. rubra (red oak), Phytophthora ramorum on, S1.8

Tubakia spp. on, S4.142

Xylella fastidiosa subsp. multiplex on, in midAtlantic, S4.11

Quesada, L., S5.4

Quesada-Ocampo, L. M., S4.47

Quinoa. See Chenopodium quino

Quinone outside inhibitor fungicides (QoI)

for Alternaria alternata on tangerine, geographic and cultivar distribution of resistant isolates, S4.127

for Cercospora sojina on soybean, characterization of sensitive and resistant isolates, S4.143

for Exserohilum turcicum, baseline sensitivity to, S4.21

mechanisms of resistance of Botrytis cinerea to, S4.4

resistance to, in Botrytis cinerea on apple, 315

Rhizoctonia solani on rice and, detection of resistance, $\mathrm{S} 4.88$

for Venturia inaequalis, development of resistance to, S4.42

Quirin, E., S4.15

Quito-Avila, D. F., 547, S4.96

Quorum sensing

Burkholderia glumae on rice and, S2.2, S4.148

hshB gene and Xanthomonas oryzae pv. oryzicola virulence, 252

in Pantoea ananatis, S4.109

virulence of enteric plant pathogens and, S4.147

virulence of Xanthomonas oryzae pv. oryzicola on rice and, 84

$R$ genes

organ-specific modulation of through transcription, S4.15

SolaR80 system for comprehensive survey of in solanaceae, S4.15

Radionenko, M., S4.50

Rahman, A., S4.96

Rahman, M., S3.4, S4.96

Rahman, M. A., S4.153

Rai, H., S4.102

Raid, R. N., S4.97

Rain

dispersal of primary inoculum of Plasmopara viticola on grape and, 158

simulated, to evaluate pyraclostrobin removal in citrus crops, S4.46

Rajashekara, G., 177

Rajotte, E., S4.153

Rallos, L., S3.1

Ralstonia solanacearum

CANARY assay for, S4.97

characterization of biofumigated cells using microRaman spectroscopy and electron microscopy, 105

comparative analysis of techniques for detection of race 3 biovar 2 and native strains, S4.121 
comparative effect of low temperature on viru-

lence and twitching motility of strains in

Florida, 185

populations from Côte d'Ivoire in Africa, 733

temperature adaptation, disease incidence and,

S4.56

on tobacco

comparison with strains from vegetables, S4.122

effect of temperature on resistance, $\mathrm{S} 4.12$

on tomato

Bacillus subtilis biofilm formation and biological control of, S4.21

filamentous phage $\phi R S S 1$ and virulence, 244 grafting for management of, S4.85

loss of virulence through infection in fRSM

filamentous phages, 469

in Puerto Rico, S6.5

transcriptomic and genetic analysis of resistance, S4.151

on vegetables, comparison with strains from

tobacco, $\mathrm{S} 4.122$

Ram, T., 222

Ramadugu, C., S4.63, S4.67, S4.97

Ramaekers, L., S4.26

Ramalho, T. O., S4.97

Raman, V., S3.4

Rambutan. See Nephelium lappaceum

Ramming, D. W., 83

Ramos, R., S6.1

Ramos Molina, L. M., S4.97

Randall, J., S4.73, S6.10

Randall, J. J., S4.114

Ranger, C. M., S4.144

Rani, N. Shobha, 222

Rank regression, for analyzing ordinal qualitative data for treatment comparison, 1064

Ranunculus mosaic virus, identification of in Great Smoky Mountains National Park, S4.2

Ranunculus repens (creeping buttercup), novel

Marafivirus from, S4.2

Raper, R. L., S2.5

Rapicavoli, J., S4.147

Rapid Cycling Brassica Collection (RCBC), reaction to Canadian pathotypes of Plasmodiophora brassicae, $\mathrm{S} 4.108$

Rappaport, K., S4.15, S4.97, S4.156

Raruang, Y., S2.4, S4.40

Rascoe, J., S4.84

Rascoe, J. E., S4.66

Rashed, A., 1079, S4.129, S4.137

Rasmussen, J. B., S4.52, S4.108

Raspberry. See Rubus spp.

Raspberry latent virus (RpLV), in raspberry,

transmission biology of, 547

Ratcliffe, S. T., S4.54

Rath, M., S4.16

rAUDPS. See Relative area under the disease progress stairs

Rauscher, G., 443

Ravanlou, A., S4.8

Ravindran, A., 899, S6.4

Ray, J., S4.68

Ray, R. V., S4.98

Rayapati, N., S4.98

Rayapati, N. A., S3.3, S4.9, S4.60

RBSDV. See Rice black-streaked dwarf virus

RCNMV. See Red clover necrotic mosaic virus

Reactive oxygen species (ROS). See also Oxidative stress response

efficacy of the fluorimetric probes dichlorofluorescein (DCFH) and Amplex Red in estimating, S5.2

Magnaporthe oryzae on barley and, MoHyr1,

MoyAP1 and, S4.55

Pantoea stewartii subsp. stewartii on corn and, S4.17

Plasmodiophora brassica progression from cortical to stele cells and, S4.29

Pseudomonas syringae on Arabidopsis thaliana and, 662
Pyricularia oryzae on wheat and, 1121

sensor of in Magnaporthe oryzae, S3.2

Real-time PCR

for Agrobacterium vitis on grape, magnetic capture hybridization and, S4.59

for Asian prunus viruses, Plum bark necrosis stem pitting associated virus, and Peach latent mosaic viroid, $\mathrm{S} 4.71$

for Bean pod mottle virus, S4.20

for Calonectria pseudonaviculata on boxwood, $\mathrm{S} 4.26$

for detection and discrimination of Maize dwarf mosaic virus, Sugarcane mosaic virus, and Sorghum mosaic virus, S4.89

for detection and quantification of trifloxystrobinresistant strain of Venturia inaequalis on apple, S4.128

for distinguishing among Cherry leafroll virus,

Grapevine fanleaf virus, and Tomato ringspot virus, $\mathrm{S} 4.20$

for Fusarium oxysporum f. sp. lycopersici in soil, S4.56

for Fusarium virguliforme on soybean, S4.131

for genus- and species-level Pospiviroid identification, S4.47

for grapevine viruses, S4.92

for multiple seedborne spinach pathogens, S4.38

Pentalonia nigronervosa, Banana bunchy top virus and, S4.16

for Plasmopara halstedii in sunflower seeds, 908

for Pratylenchus thornei in soil, 14

for Verticillium dahliae on spinach seed, 443

for viruses in grapevine, $\mathrm{S} 4.82$

for Xylella fastidiosa on oleander, S4.48

Rebollar-Alviter, A., S4.15, S4.110

Recce, S., S3.4

Recombinase polymerase amplification (RPA), for

Plum pox virus, $\mathrm{S} 4.143$

Recombination, emergence of two highly divergent

spinach curtoviruses from, S4.52

Records, A., S4.166

Red clover necrotic mosaic virus (RCNMV), gene

expression during infection with, S4.119

Red oak. See Quercus rubra

Reddy, C. S., 222

Reddy, M. S., S4.144

Redinbaugh, M., S4.25, S4.80

Redinbaugh, M. G., 1176, S4.114, S5.7, S5.10

Reding, M. E., S4.144

Reed, D. L., 924

Reed, S., S4.70

Regulation of pathogenicity factors (RPF) genes,

Xylella fastidiosa on grape and, 1045

Regulatory issues. See also Deregulation of biotech crops

of biotechnology for disease management, S4.154

case-based analysis of information sources, sinks, and loops in, S4.163 current processes involved in deregulation, S4.152

decision-making in, S4.163

historical perspective of deregulation, S4.151 role of epidemiology research in shaping, S4.163

Rehfeldt, G. E., S4.137

Reinhardt, T., S4.112

Reininger, V., S4.98

Reisch, B. I., S4.18

Reitz, S. R., S4.98, S4.133

Relative area under the disease progress stairs (rAUDPS), 381

Relative humidity, Fusicladium carpophilum on nectarine and, 421

Remenant, B., S4.151

Ren, J., S4.130

Renzi, M., 827

Resende, R. S., 892

Resistance, chemical

ABC transporter gene from Sclerotinia homoeocarpa and, S4.105 of Alternaria spp.

A. alternata: against fluopyram, S4.84; against

QoI fungicides, S4.127

against azoxystrobin, S5.3

ATRl gene, against cercosporin and, S4.53

against azoxystrobin

of Alternaria spp. on potato, S5.3

of Bipolaris spp., alternative mechanisms of, S4.120

of Bipolaris spp., against azoxystrobin, alterna-

tive mechanisms of, S4.120

of Blumeriella jaapii, against boscalid, on tart

cherry, S5.8

against boscalid

of Blumeriella jaapii, on tart cherry, S5.8

of Didymella bryoniae, in Florida isolates,

S4.52

of Botrytis cinerea

against fenhexamid, S4.47

against fluopyram, S4.84

against multiple fungicides, $\mathrm{S} 4.38$

against pyraclostrobin, 315

against respiration inhibitors, S2.3

broad-spectrum, of Uromyces appendiculatus on

bean, $\mathrm{S} 4.90$

of Cercospora beticola, on sugar beet, S5.2

against cercosporin, ATRl gene and, S4.53

of Corynespora cassiicola on tomato, S4.2

against demethylation inhibitor fungicides

of Mycosphaerella graminicola, S4.41

of Venturia inaequalis, 272

detection and management, of Fusarium spp. on potato, S4.92

of Didymella bryoniae on watermelon, to

boscalid, in Florida isolates, $\mathrm{S} 4.52$

against dodine, of Venturia inaequalis, S4.26

dual resistance, fungicide-mediated transposition of genetic elements, of Monilinia fructicola and, S4.21

effect of fungicide dose rate on emergence of, S4.54

Erwinia amylovora on apple, against streptomycin of, S4.60

EST analysis for candidate genes involved, in of Phytophthora infestans, S4.20

against fenhexamid, in Botrytis cinerea on strawberry, S4.47

against fluopyram, in Alternaria alternata and

Botrytis cinerea, $\mathrm{S} 4.84$

of Fusarium spp. on potato, detection and management of, S4.92

of Guignardia citricarpa on citrus, against stroliburin-class fungicides, S4.53

against Magnaporthe oryzae on rice, identification of Pib gene in National Small Grains Collection and, 700

against mefenoxam, in Phytophthora infestans, S4.84

of Monilinia fructicola dual resistance, fungicide-mediated transposition of genetic elements and, S4.21 new mechanism of DMI fungicide resistance in, $\mathrm{S} 2.2$

of Monilinia vaccinii-corymbosi, against propiconazole, S4.119

against multiple fungicides, Botrytis cinerea on strawberry, S4.38

of Mycosphaerella graminicola, to DMI fungicides, S4.41

of oilseed rape, against Pyrenopeziza brassicae, S4.19

of Penicillium spp.

from decayed fruit, to thiabenzole in, S4.43

$P$. expansum on apple, against pyrimethanil, S4.18

of Phytophthora infestans

EST analysis for candidate genes involved in, S4.20

against mefenoxam, S4.84 
of Plasmopara viticola, against stroliburin-class fungicides, G143A mutation and, S4.23 against propiconazole, of Monilinia vacciniicorymbosi, $\mathrm{S} 4.119$

against pyraclostrobin, of Botrytis cinerea on apple, 315

in Pyrenopeziza brassicae on oilseed rape, S4.19 against pyrimethanil, in Penicillium expansum on apple, $\mathrm{S} 4.18$

against QoI fungicides

in Alternaria alternata, S4.127

in Rhizoctonia solani on rice, $\mathrm{S} 4.88$

in Venturia inaequalis, $\mathrm{S} 4.42$

against respiration inhibitors, in Botrytis cinerea, $\mathrm{S} 2.3$

of Rhizoctonia solani on rice, $\mathrm{S} 4.88$

of Sclerotinia sclerotiorum to thiophanate methyl, S5.1

against streptomycin, of Erwinia amylovora on apple, S4.60

against stroliburin-class fungicides

G143A mutation in Plasmopara viticola and, S4.23

of Guignardia citricarpa on citrus, S4.53

against thiabenzole, in Penicillium spp. from

decayed fruit, $\mathrm{S} 4.43$

against thiophanate methyl, of Sclerotinia sclerotiorum, S5.1

against trifloxystrobin, of Venturia inaequalis,

real-time PCR for detection of resistant strain,

S4.128

of Uromyces appendiculatus on bean, broad-

spectrum, S4.90

of Venturia inaequalis

CYP51A1 overexpression and, S4.128

against dodine, in northeastern US popula-

tions after renewed use of Syllit for apple

scab management, S4.26

against fungicides, CYP51A1 overexpression and, S4.128

to QoI fungicides, S4.42

against trifloxystrobin, real-time PCR for detection of resistant strain, $\mathrm{S} 4.128$

Venturia inaequalis, against demethylation inhibitor fungicides in, 272

Resistance, host. See Host resistance

Resistance gene analogs (RGA)

identification of from peanut, marker develop-

ment and, S4.71

from peanut ESTs, S2.7

Restrepo, S., S4.18, S4.80, S4.117

Reyes-Valdes, M., S4.138

Reynolds, A.M., 1026

Reynolds, G. J., S4.99

Rezende, J., S4.99

Rhgl locus, soybean cyst nematode development

and, S4.26

Rhizobacteria

antagonistic to plant pathogens, characterization and genetic analysis of, S2.7

Bacillus subtilis IN937b, for control of Phytophthora capsici on squash, S4.81

Rhizobium spp.

R. etli strain G12, induction of resistance against Meloidogyne incognita and, 260

Macrophomina phaseolina on green gram and, S4.85

R. vitis, nonpathogenic strains, for control of grapevine crown gall, S4.62

Rhizoctonia spp.

LAMP assays for detection of, S4.91

methods for isolation and quantification of, S2.9 R. solani

AG-1 IA, genetic structure of sympatric populations from Brachiara and rice, S4.97

biorational alternatives for control of, S4.66 on carrot, evaluation of seed treatments for, S5.1 on cucumber (organic), natural products for suppression of, S3.4, S4.100

in fields undergoing rice and soybean rotations, spatial assessment of, S4.113

on peanut, effect of initial fungicide application timing and cultivar on, S2.10

on potato, in Idaho and Michigan, characterization and pathogenicity of isolates, S4.135

on rice: antagonistic activities of rice-associated bacteria, S2.8; brassica biofumigation cover crop and plant growth-promoting rhizobacteria for control of, S4.144; Qol resistance and, S4.88; screening for biofumigants for, S6.2

on soybean: cover crops for suppression of, S4.134; interaction with soybean cyst nematode, S5.4; strain AG-1 IA, genetic variation and evolutionary adaptability of, S4.38 on sugar beet: azoxystrobin for control of $\mathrm{S} 5.7$; fungicides for management of, S4.63; influence of tillage systems on, S4.115; penthiopyrad for control of, S5.6; postharvest respiration rate and sucrose concentration, S4.136; seed and in-furrow fungicides with and without postemergence azoxystrobin for control of, S4.16

volatile organic compounds from Ceratocystis fimbriata and, $\mathrm{S} 4.70$

on wheat, natural suppression by soil microbial communities at decline site, S4.141

on zoysiagrass: in Kansas, S4.86; toothpick

baiting method for detection and monitoring of, S6.4

Rhizopus stolonifer, on sweet potato, hot-water baths for treatment of, S2.10

Rhizosphere

metagenomics and Metabolomics for analysis of, S4.159

plant host effects on, S4.6

Rhoads, J., S2.4

Rhododendron, Phytophthora ramorum on, abiotic

stress, root infection, symptom expression, and chemical management, S4.103

Rhododendrons, Phytophthora cinnamomi on, flooding stress and, S4.65

Rhopalosiphum padi, sweet potato potyviruses and, S4.138

Rhus typhina (staghorn sumac), extracts from for control of Phytophthora sojae, S5.1

Rhynchosporium commune, thermal adaptation in, S4.114

Ri, C., S4.141

Riaño, J., S4.112

Riaño-Pachón, D., S4.117

Ribes spp., Gooseberry vein banding associated virus in, of National Clonal Germplasm Repository, S4.100

Ricci, A., S4.82

Rice. See Oryza sativa

Rice black-streaked dwarf virus (RBSDV), in corn, S4.80, S5.7

RICE-PRE, for disease prevention in rice, $\mathrm{S} 4.113$

Richards, C. J., S4.78, S6.4

Richardson, B., S4.102

Richardson, S., S4.99

Ricin A chain, depurination activity and cytotoxicity, S1.8

Rideout, S., S3.2, S4.39

Ridout, C. J., S4.16

Rigling, D., 73, 1161

Riley, D., S4.113

Riley, K. L., S6.8

Riley, T. D., S4.161

Rincon, M., S4.39

Rinehart, T., S4.70

Riner, C., S2.6

Rintoul, T. L., S4.101

Rios, A. A., S4.144

Rios, J. A., 1121
Rioux, D., S1.8

Rioux, R., S4.100

Risk management, globalization and management of invasive pathogens at farm level and, 609

Ristaino, J., 635

Ristaino, J. B., S4.106

Ritchie, D. F., S4.70

Rivera, L. I., S6.5

Rivera, S. A., S4.100

Rivera, V., S4.12

Rivera, V. L., S6.5

Rivera-Varas, V., 298, S5.2

Rivera-Vargas, L. I., S4.108, S6.3, S6.6

Rmo2 gene, Magnaporthe oryzae on barley and,

resistance to host-specific subgroups, 674

RNA analysis

of Sclerotinia sclerotiorum on chickpea and lentil, S4.95

of soil microbes in organic vs. conventional vegetable production, $\mathrm{S} 4.46$

RNAi-mediated silencing

of Phytophthora capsici, S4.114

resistance of soybean against Heterodera glycines and, S4.69

Robert, C., S4.92

Roberts, D., S4.100

Roberts, D. P., 575, S3.4

Roberts, M. J., S2.7

Roberts, P., S2.3

Roberts, P. D., S4.35, S4.52, S4.65, S4.66

Roberts, S. M., S4.100

Robertson, A., S4.1, S4.75, S4.77, S5.7, S5.8

Robertson, A. E., S4.1, S4.21, S4.101, S4.102, S5.6

Robertson, C. L., 749, S4.107

Robertson, D., S4.83

Robertson, N. L., S4.100

Robideau, G. P., S1.5, S4.101

Robinson, T. S., S4.101

Robleh Djama, Z., S4.22

Robles-Hernandez, L., S4.46, S4.101

Rocateli, A. C., S2.5

Rockey, W. D., S4.101

Rodrigue, N., S1.5, S4.113

Rodrigues, F., S4.40

Rodrigues, F. Á., 892, 957, 1121

Rodrigues, R. A., S4.101

Rodriguez, A., S6.5

Rodriguez, D., S4.162

Rodriguez, D. A., S4.122

Rodriguez, G. H., S4.37

Rodriguez-Herrera, J. A., S6.6

Rodriguez-R, L. M., 948

Roe, B. A., 166

Rogers, E., S4.102

Rogers, E. E., 32, S4.67

Roitsch, T., 662

Rojas, A., S4.102, S5.8

Rollins, J. A., 506

Romanazzi, G., 290

Romberg, M. K., 1034

Romero, G. C., S6.5

Romero, M. P., S4.102

Romero Luna, M. P., S5.8

Rommens, C., S4.151

Rondon, S. I., S4.8

Rong, X., S5.8

Rooney-Latham, S., S4.60, S4.90, S6.12

Roop, D. J., S4.62

Roossinck, M., 166

Roots, early infection and damage during huanglong-

bing disease development, S4.59

Roper, M., S4.17, S4.147

ROS. See Reactive oxygen species

Rosa sp.

Rose yellow mottle virus in, $\mathrm{S} 4.82$

Rose yellow vein virus in, $\mathrm{S} 4.82$

Rose yellow mottle virus and Rose yellow vein virus, in Rosa sp., S4.82

Rosenberger, D. A., S1.7 
Rosenblum, E. B., S4.162

Rosenzweig, N., S4.102

Rosetta, R., S4.144

Ross, R. E., S3.2

Ross, S., S3.4

Ross-Davis, A., S4.102

Ross-Davis, A. L., S4.63

Rossetti, A., 827

Rossi, V., 158, 707, S4.68

Rosskopf, E. N., S4.153

Rossman, A. Y., S4.16, S4.26

Rosso, M.-N., 990

Rotenberg, D., S4.149

Roth, B., S6.12

Rothrock, C., S4.113

Rothrock, C. S., S2.3, S2.9

Rothwell, N. L., S4.68

Rotich, F., S4.37

Rotondo, F., 1130

Rott, P. C., S4.39

Rotylenchulus reniformis (reniform nematodes), on

cotton, nitrogen rate and Telone II treatment, S2.5

Roubtsova, T. V., S4.100, S4.103

Rough lemon. See Citrus jambhiri

Roundup Ready cropping systems, Fusarium virguli-

forme on soybean and, S4.140

Rouse, D. I., S4.45

Rouse, M., S4.145

Rowhani, A., S4.74

Roy, A., S4.24, S4.103

RoyChowdhury, M., 700

RoYMV, Rose yellow mottle virus

RPA. See Recombinase polymerase amplification

RpeA and RpeB, phenazine biosynthesis by Pseudomonas chlororaphis strain 30-84 and, S4.130

Rpf genes. See Regulation of pathogenicity factors (RPF) genes

RpLV. See Raspberry latent virus

RprA, Erwinia amylovora virulence and, S4.142

rsmA, from Pseudomonas aeruginosa, virulence of

select phytotoxin-producing strains of $P$. syringae and, 575

Rubio, I., S4.103

Rubrifacine, AHL signals and production of by

Brenneria rubrifaciens, 195

Rubus spp. (blackberry)

Botrytis spp. on

characterization and detection of new species, S 2.7

in southeast United States, S4.68

differential susceptibility of non-native species to

Phragmidium violaceum, S3.2

genetic variation of novel ampelovirus in, S4.119

Leptosphaeria coniothyrium on, effect of early

floricane removal and fungicides on, S3.4

Peronospora sparsa on, S4.15

Rubus spp. (raspberry), Raspberry latent virus in,

transmission biology of, 547

Rudolph, K., S4.12

Rudolph, K. D., 298, S5.2

Rudyj, E. S., S4.154

Rugh, A. L., S1.7

Ruiz-Arce, R., S6.3

Rumohra adiantiformis (leatherleaf fern), S4.104

Rupe, J., S4.25, S5.8

Rupe, J. C., S2.3, S4.102

Rush, C. M., 1079, S4.94, S4.129, S4.137

Rush, M. C., S2.8

Rush, T. A., S4.103, S4.132

Russell, P., S4.47, S4.143

Russia, emerging plant pathogens in, $\mathrm{S} 4.57$

Ruud, A., S4.116

RXLR, conserved modular domains found in, S4.165

Rybarczyk-Mydlowska, K., 1153

Rye. See Secale cereale

Ryegrass. See Lolium spp.

RyhA, Erwinia amylovora virulence and, S4.142

Ryu, Y., S4.104

RYVV. See Rose yellow vein virus
Saad, A. T., S4.104

Sabanadzovic, S., S4.2, S4.104, S4.119, S4.126

Sabaratnam, S., S4.121

Saccharum spp. (sugarcane)

Leifsonia xyli on, methods of DNA extraction for, S4.124

Meloidogyne kikuyensis on, morphology and molecular biology, S4.34

Peronosclerospora spp. on, repeating structure of internal transcribed spacer region 2 in, $\mathrm{S} 4.73$

Puccinia kuehnii on reaction of thirteen varieties, in Brazil, S4.82 resistant varieties in Brazil, S4.13

white leaf phytoplasma in, seed transmissibility of, S4.76

Xanthomonas albilineans on, OmpA and disease symptom development and colonization, S4.39

Xanthomonas axonopodis pv. vasculorum on, in Mexico, S4.110

Sadof, C., S4.10

Safitri, R., S4.122

Sagi, M., S4.81

Saha, G., S4.104

Saha, M. C., S4.157

Sailsbery, J., S4.104

Saito, S., S4.104

salA regulatory network, Pseudomonas syringae pv. syringae $\mathrm{B} 728 \mathrm{a}$ on bean and, S4.126

Salazar, C. A., S4.43

Salgado, J., S5.8

Salgado, J. D., S4.28, S4.105

Salicylate hydroxylase, of Candidatus Liberibacter

asiaticus, Xanthomonas citri subsp. citri and, S4.121

Salicylic acid

for control of Magnaporthe oryzae on rice, S4.126

identification of signaling networks in plant immunity, S4.119

for suppression of clubroot in Arabidopsis thaliana and Brassica oleracea, S4.72

Salinity

modulation of plant resistance to viral pathogens by, S4.81

Phytophthora capsici on tomato and, S4.95, S6.12

sequencing of date palm transcripts in response to, $\mathrm{S} 4.96$

Salivary sheaths, new method for studying, S4.5

Salmonella spp.

on cantaloupe, Erwinia tracheiphila and, S4.44

S. enterica

growth in tomato phyllosphere, synergistic interaction with Xanthomonas perforans and, S4.94

proteomic analysis of plant colonization by, S4.66

survival in water, S4.99

on tomato: ingress into tomato leaves, soil management and, S4.48; water as vehicle for transport, S4.126

transmission to crops by western flower thrips, S4.112

on tomato, detached leaf assay for modeling contamination, S4.9

Salt stress. See Salinity

Samac, D., S4.105

Samils, B., 1006

Sams, C., S4.14

Samy, A. M., S2.1

Sanchez, E., S6.1

Sánchez, M. I., 974

Sanchez Borges, R., S6.2

Sanchez Perez, A., S4.44

Sanchez-Chavez, E., S4.46

Sanchez-Navarro, J. A., 1108

Sanchez-Pina, M. A., 1108

Sanders, F. Jr., S2.6

Sanderson, J. P., 283

Sang, H., S1.4, S4.56, S4.105
Sanitary and Phytosanitary (SPS) Agreement, trade concerns and disputes under, S4.163

Sanogo, S., S4.73, S4.114, S6.7, S6.10, S6.12

Santos, L. S., S4.27

Santos, M. C., S4.125

Santos, M. D., S4.105, S4.111

Saponari, M., 1168

Sapwood, relative potential of major root-rot and

bole-rot fungi to decay, S4.136

SAR. See Systemic acquired resistance

Saraihom, S., S4.105

Satar, S., 1168

Satellite RNAs, associated with Grapevine fanleaf virus in grapevine, $\mathrm{S} 4.46$

Sato, M., S4.23

Satpute, A., S4.110

Sattler, S. E., S4.157

sAUDPS. See Standardized area under the disease progress stairs

Savary, S., S4.113, S4.135, S4.162

Savchenko, T., S4.100

Savidor, A., 23

Saville, A., S4.106

Savino, V., 1168

Scales, decision-making at different, S4.162

Schäfer, W., S4.146

Schaub, M., S4.18

Schaub, T., S6.12

Scheets, K., S4.165

Scheiding, S., S4.75

Schereffer, J.-L., 908

Scherm, H., S4.36, S4.54

Schilder, A. C., S4.106, S4.150

Schiller, C. T., S4.135

Schillinger, W., S4.141

Schisler, D. A., S5.8

Schlub, R. L., S4.106

Schmale, D. III, S3.4

Schmid, C. J., S1.7

Schmidt, L. S., S4.16, S4.106

Schmitt, M., S4.86

Schnabel, G., S2.2, S2.3, S2.7, S4.21, S4.38, S4.47, S4.68

Schneider, R. W., 749, S4.103, S4.107, S4.132

Schneider, W. L., S4.35, S4.114, S4.115, S4.155

Schnittker, R., S4.167

Schoelz, J. E., S4.5, S4.6

Schoen, C., 635

Schoenmakers, N., 140

Scholthof, H. B., S4.81

Schouten, A., 260

Schrader, O., S4.136

Schroeder, B. K., S4.32, S4.107, S4.125

Schroeder, K., S6.8

Schroeder, K. L., S4.141

Schrotenboer, A. C., S4.157

Schtienberg, D., 769

Schubert, T. S., S4.163

Schuenzel, E., S6.1, S6.3

Schuenzel, E. L., S6.5, S6.6

Schuerger, A. C., 794

Schuler, H., 878

Schulman, P., S4.82

Schwartz, H. F., S4.107

Schweiger, W., S4.146

Schweri, K., S4.107

Sciumbato, G., S4.133

Sclerotinia spp.

S. homoeocarpa

$\mathrm{ABC}$ transporter gene from, propiconazole resistance and, $\mathrm{S} 4.105$

on creeping bentgrass: irrigation management of, S4.33; weather-based fungicide application advisor for, S4.111

genetic analysis of worldwide populations with mating type and microsatellite markers, S4.95

heterokaryon formation and nuclear disproportion in, $\mathrm{S} 4.63$ 
model plants for use in elucidation of pathogenesis, S4.100

morphological, vegetative, genetic, and mating type diversity in, 506

propiconazole-resistant: overexpression of BcatrD homolog from, S1.4; overexpression of ShCYP51B and ShatrD in, S4.56 semiselective media for enhanced detection from plant tissues, $\mathrm{S} 4.100$

on turfgrasses: influence of dew removal methods and plant growth regulators on fungicide efficacy for the control of, S4.56; molecular detection and host adaptations, S4.7; species boundaries between members of the Sclerotiniaceae and Rutstroemiaceae, S1.1

isolate of for control of ground ivy, S4.96

$S$. minor, on peanut, fluopyram and cultivar selection for management of, S2.11

S. sclerotiorum

application of selected fungal endophytes and Coniothyrium minitans against, S4.12 on canola, fungal gene expression patterns during infection, $\mathrm{S} 4.23$

characterization of metconazole sensitivity in north central United States, S4.4

on chickpea and lentil, transcriptome analysis using RNA sequencing, S4.95

colonization by Aphelenchoides sp., S6.9

on common bean, in upper Egypt, S2.1

detection of intrachromosomal recombination in, S4.7

on peanut: factors affecting mycelium pigmentation and pathogenicity of, S4.73; oxalic acid productio, mycelium pigmentation and, S6.10

on potato, field flooding for control of, S6.11 resistance to thiophanate methyl, S5.1 on soybean, assessing biological control agents for, S5.4

on sunflower, identifying resistant germplasm, S4.12

S. trifoliorum, on chickpea, transcriptome analysis of interaction, S4.95

Sclerotium spp.

S. cepivorum, on onions and garlic, combining sclerotia germination stimulants and fungicides for control of, S4.39

S. rolfsii

pathogenic and genetic diversity in isolates in southern U.S., S4.139

on tomato: effects of conventional, organic, and no-till field soils on development of, S4.30; soil and foliar fungicide applications $\mathrm{S} 2.7$

SCMV. See Sugarcane mosaic virus

SCTAzV. See Spinach curly top Arizona virus

SDA1 (sorbitol dehydrogenase activator), Fusarium

verticillioides polyol pathway and, S6.1

Seashore paspalum. See Paspalum vaginatum

Seavert, C. F., S4.155

Seaweed extracts. See Asophyllum nodosum extracts

Sebastian, E., S6.6

Secale cereale (rye), Puccinia graminis on, genetic

variation in, 1006

Secor, G., S4.12, S5.2

Secor, G. A., 298

See, D., S4.145

See, D. R., S4.22, S4.30

Seed

Acidovorax citrulli on watermelon and, S2.10

sugarcane white leaf phytoplasma transmissibility and, S4.76

wheat, chlorine dioxide for disinfection of, S4.59

Zucchini yellow mosaic virus transmission in,

S1.7

Seed meals, for apple replant disease, S4.77

Seed treatments

for control of Fusarium spp. on legumes, S4.52 for control of Rhizoctonia solani on carrot, S5.1 ethoboxam for Phytophthora spp. and Pythium

spp.

amended agar and greenhouse assays for, S4.31 efficacy of, S4.31

non-thermal plasma for control of seedborne

pathogens in, S6.1

for Verticillium dahliae on spinach, S6.8

Seem, R. C., 65, S4.7, S4.18, S4.42, S4.83, S4.116

Segura-Ledesma, S. D., S4.15

Seidl, A. C., S4.107, S5.9

Seifers, D., S4.42

Seifers, D. L., S5.2

Seifert, K. A., S4.22

Seijo, T., S4.80, S4.107

SEIR model. See Susceptible, exposed, infected, and

removed (SEIR) compartmental model

Semenov, A. M., 413

Sentinel plant systems, for tracking Phytophthora

ramorum disease, $\mathrm{S} 4.90$

Seo, E., S4.69

Septoria passerinii, on barley, identification of novel resistance loci, 683

Septoria tritici, on wheat, epidemiology and

management in Ontario, S4.17

Serba, D., S4.157

Serna, N. F., 948

Serological tests, of transgenic crops, S4.51

Serrato-Diaz, L. M., S4.108, S6.3, S6.6

Sesarma reticulatum (purple marsh crab), herbivory

of on Spartina alterniflora, influence of Fusarium

palustre, drought, and DMSO, S4.34

Sessa, G., 23, S4.20

Sétamou, M., S4.66

Sether, D., S4.131

Sether, D. M., 122, S1.6

Sexton, Z. F., S5.9

Seybold, S. J., S4.159

Shaik, H., 222

Shang, S. H., 267

Shantharaj, D., S4.108

Shao, J., S3.3, S4.48, S4.103, S4.143

Shapiro, A. A., 41

Sharlach, M., S4.148

Sharma, K., S4.78, S4.108

Sharma, M., S4.108

Sharma, P., S4.108

Sharma, S. K., 105

ShatrD gene, Sclerotinia homoeocarpa propiconazole

resistance and, $\mathrm{S} 4.56$

Shaw, M., S4.19

Shea, T., S4.11

Shen, Q., 252

Shen, Y., S4.144

Shennan, C., S4.77

Shepherd, L. M., S4.101

Sherwood, J. L., S2.4

Sherwood, P. W., S5.9

Sheshu Madhav, M., 222

Shetty, K., S4.52

Shew, B., S4.72

Shi, J. X., 267

Shiel, P., S4.108

Shier, W., S4.1

Shih, S., S4.122, S4.146

Shim, W., S6.1, S6.4

Shin, D., S6.1

Shin, S.-H., S4.90

Shipping point inspection program (SPI), incidence

of five common pests in nurseries participating in S4.89

Shirsekar, G., S4.165

Shjerve, R. A., S4.108

Short, D. P., S4.48, S4.109

Shrestha, A., S4.113

Shrestha, B. K., S2.6, S2.8

Shrestha, S. K., S2.9, S4.109

Shyntum, D., S4.109

Sibanda, P., S4.109
Sieber, T. N., S4.98

Sierotzki, H., S4.88

Sigma factors, Erwinia amylovora virulence and,

S4.70

Sikdar, P., S4.109

Sikora, K., 635

Sikora, R. A., 260

Silencing

broad spectrum virus resistance and, S5.4

influence of parasitic interactions on, S4.130

of Phytophthora capsici, S4.114

resistance of soybean against Heterodera glycines and, S4.69

Silicon

and banana resistance to Fusarium oxysporum $\mathrm{f}$. sp. cubense, $957, \mathrm{~S} 4.40$

for control of Phytophthora capsici on tomato, S4.80

and ryegrass resistance to Magnaporthe oryzae, S4.96

and sorghum resistance to Colletotrichum sublineolum, leaf gas exchange and oxidative stress and, 892

Silva, C. A., S4.82

Silva, F. F., S4.112

Silva-Rojas, H. V., S4.15, S4.110, S6.6

Simard, M., S1.8

Simko, I., 381, S4.110, S4.136

Simmons, A., S4.94

Simmons, H. E., S1.7

Sims, K., S2.10

Sims, K. R., S4.90

Singer, B. H., S4.23

Singh, A., S2.9

Singh, D., S4.108

Singh, D. K., S4.110

Singh, M., S4.149

Singh, R., S4.48

Singh, S. K., 620

Sinorhizobium meliloti, strain 1021, 'Ca. Liberibacter asiaticus' genes orthologous with pSymA-borne genes, S3.3

Sipes, B., S4.6

Sirex spp. (woodwasps), screening fungal symbionts of, S4.87

Si-RNAs, in maize, hotspots in viral accumulation, S4.165

Sisterson, M., S4.141

Sisymbrium irio (London rocket), inhibitory effect of volatiles of on soilborne pathogens of chili pepper, S6.12

Sit, T. L., S4.119

Skaria, M., S4.66, S4.110

Skelsey, P., S4.161

SkyBit 2011, reliability and accuracy of in Pennsylvania, S4.49

Small, I. M., S4.28, S4.84, S4.110, S4.118

Small RNAs, virulence of enteric plant pathogens and, S4.147

Small subunit ribosomal DNA-based phylogenetic analysis, of Aphelenchoides spp., quantitative detection in complex DNA backgrounds and, 1153

Smallwood, E. L., S3.1

Smart, C. D., S4.32, S4.60, S4.66, S4.115, S4.118

Smart spray systems, for enhanced pesticide delivery, S4.144

Smilanick, J. L., 83

Smilax rotundifolia (greenbriar), micro-fungal populations of, S1.8

Smiley, R. W., 14

Smith, A. D., S4.111

Smith, B. J., S2.8, S4.111

Smith, C. A., S4.24

Smith, D. L., S4.111

Smith, D. R., S4.111

Smith, J., S4.68

Smith, J. E., S2.9

Smith, M. E., S4.159 
Smith, P. B., S4.110

Smith, T. J., S4.151

SNEGIN. See Southern New England Grape Information Network

Sneller, C., 306, S5.6

Sneller, C. H., S5.5

SNSV. See Strawberry necrotic shock virus

SnTox4-Snn4 interaction, Stagonospora nodorum on wheat and, 94

Soares, W. R., S4.111

Soby, S., S4.112

Soby, S. D., S4.20

Soil

anaerobic soil disinfestation for control of disease in strawberry, S4.77

disease suppressive, seed-colonizing bacterial communities associated with, suppression of Pythium seedling disease and, 478

Fusarium oxysporum f. sp. lycopersici in, S4.56

microbial composition in organic vs. conventional vegetable production, $\mathrm{S} 4.46$

Phytophthora ramorum in, steam disinfection of, S4.59, S4.60

Plasmodiophora brassicae severity and, S4.46

Pratylenchus penetrans on potato, commercialscale soil test data and, S4.45

Pratylenchus thornei in, 14

Sclerotium rolfsii on tomato and, effects of conventional, organic, and no-till field soils on, S4.30

Verticillium dahliae in, S4.45, S6.10

Soil amendments

and banana resistance to Fusarium oxysporum $\mathrm{f}$. sp. cubense, 957

Pythium ultimum and

carbon competition in spermosphere, pathogen and disease suppression in municipal biosolids compost and, 588 on sugar beet, 413

Soil solarization, Pratylenchus penetrans and Ver-

ticillium dahliae on potato and, 519

Soil-borne disease, assessing organic growers' beliefs regarding management of, $\mathrm{S} 4.10$

Solano, F., S4.50

Solanopyrone, Ascochyta rabiei on chickpea and, S4.64

Solanum spp.

S. betaceum (tree tomato)

Colletotrichum acutatum on, in Ecuador, S4.94 Colletotrichum spp. on, in Colombia, S4.18

S. lycopersicoides (wild tomato), Botrytis cinerea on, molecular and biochemical characterization of resistance, $\mathrm{S} 2.9$

S. lycopersicum (tomato)

Alternaria arborescens on, horizontal gene transfer and, S4.161, S5.5

Candidatus Liberibacter solanacearum on: effects of on fitness of insect vector, 41 translocation and quantification of, S6.4

Clavibacter michiganensis subsp. michiganensis on: colonization under different humidity regimes, 177; GFP-labeled, colonization and movement during infection, 23; LAMP assays for detection of, S4.141; production of DAPG and HCN by Pseudomonas sp. LBUM300 and biological control, 967

Columnea latent viroid in, in West Africa, S4.9

Corynespora cassiicola on, resistance to respiratory inhibitors in isolates from Florida S4.2

effect of mixed- and single-species green manures on diseases and nematodes of S4.36

Fusarium oxysporum f. sp. lycopersici on: effect of plant products on rhizosphere population of, S4.126; genetic relationships among subpopulations of competitive nonpathogenic strains, S4.132
Fusarium oxysporum on: diversity of endophytic populations, S4.29; endophytic populations as host adapted, S4.29; genetic relationships among subpopulations of competitive nonpathogenic strains, S4.132

Geotrichum candidum on: effect of irrigation regimes on, S4.39; non-invasive inoculation method to evaluate post-harvest disease management strategies, S3.2

grafting in, to manage soilborne pathogens, S4.153

Groundnut ringspot virus and Tomato chlorotic spot virus in, thrips transmission of virus reassortment, $\mathrm{S} 4.133$

impact of divergent land management practices on crop health, 597

integrated pest management for, farmer participatory approach and, S4.62

Leveillula taurica on, in central California, S6.7

optimization of copper resistance testing for foliar pathogens of, S4.14

organic, impact of mixed-species cover crops on rhizosphere pathogens of, S4.115

Penicillium spp. on, in British Columbia, S6.11

Pepino mosaic virus in, shift in North America to Chilean genotypes of, S4.71

Phytophthora capsici on: early infection, salt stress of roots and, S4.95, S6.12; SAR inducers, chitosan, and silicon for control of, S4.80

Phytophthora infestans on: assessing fitness of new clonal lineages by comparing sporangial production, S5.9; genotype distribution in Canada in 2011, S4.62; oospore formation and, S4.44; phenotypic variation within a clonal lineage in Nicaragua, 323; transmission by seedlings but not seed, S4.78

Potato virus $Y$ in, $\mathrm{S} 1.4$

premature vine decline of, chemical and biological control of, S4.74

Pseudomonas syringae on, horizontal gene transfer and, S4.160

Pyrenochaeta lycopersici on, secretion of CDiT1 protein and, 878

Ralstonia solanacearum on: Bacillus subtilis biofilm formation and biological control of, S4.21; filamentous phage $\phi R S S 1$ and virulence, 244; grafting for management of, $\mathrm{S} 4.85$; loss of virulence through infection in fRSM filamentous phages, 469; in Puerto Rico, S6.5; transcriptomic and genetic analysis of resistance, $\mathrm{S} 4.151$

root-knot nematodes on: management using resistant rootstocks, S4.78; optimizing use of MCW-2 for control of, S4.135

Salmonella spp. on: detached leaf assay for modeling contamination, $\mathrm{S} 4.9$; ingress into tomato leaves, soil management and, S4.48; water as vehicle for transport, S4.126

Sclerotium rolfsii on: effects of conventional, organic, and no-till field soils on development of, S4.30; soil and foliar fungicide applications, S2.7

Tomato apex necrosis virus in, genetic diversity and whitefly transmission, S4.37

Tomato chlorotic dwarf viroid in, in Arizona, biological and molecular characterization of, S4.139

Tomato leaf curl Sudan virus in, molecular characterization of, S4.56

Tomato necrotic stunt virus in, in Mexico, $\mathrm{S} 4.70$

Tomato spotted wilt virus in, insecticide programs for in California, S4.122

Verticillium dahliae race 2 on, grafting for management of, S4.57
Xanthomonas spp. on: X. axonopodis pv. vesicatoria, Asophyllum nodosum extracts for control of, S3.2; cymoxanil and famoxadone for management of, S2.3; X. euvesicatoria, management in organic production systems, S4.31; kasugamycin and kasugamycin-fungicide mixtures for management of, S4.129; in Midwest U.S., S5.7; X. perforans, light-activated antibacterial nanoscale formulations for control of, S4.89

S. melongena (eggplant)

grafting of, to manage soilborne disease, S4.153

Meloidogyne arenaria on, grafting for management of, S4.104

S. raphanifolium (wild potato), Alternaria solani on, resistance in hybrids, 214

S. tuberosum (potato)

Alternaria grandis on, Phytophthora infestans and, comparative epidemiology in Brazil, S4.32

Alternaria solani on: detection and characterization of boscalid resistance in, S4.36; evaluating fungicide programs for in Wisconsin, S4.44; resistance in hybrids, 214

Alternaria spp. on, azoxystrobin resistance in, S5.3

Candidatus Liberibacter solanacearum on: effects of pathogen titer, vector numbers and feeding sites, 1079; genotyping and population genetic analysis of, S4.71; loopmediated isothermal amplification procedure for detection of, 899; psyllid source assessment in Pacific Northwest, S4.137; shifts in physiology after infection with, S4.129; translocation and quantification of, S6. 4

Candidatus Liberibacter spp. on, physiological and proteomic characterization of, S4.71

chemiluminescent dot-blot immunoassay for virus detection in, $\mathrm{S} 4.42$

Colletotrichum coccodes on: organically grown, S4.77; volatile organic compounds for control of, S4.135

Dickeya spp. on, in Russia, S4.64

early dying complex, commercial-scale soil test data and, S4.45

field flooding for controlling soilborne pathogens of, S6.11

Fusarium spp. on, fungicide-resistant, detection and management of, S4.92

genetically-engineered, reintroduction into U.S. market, S4.151

Globodera pallida on, predictive model of eradicative and management strategies for, S4.64

Helminthosporium solani on, organically grown, S4.77

longer-term cropping system for, soilborne diseases and tuber yield and, S4.67

Meloidogyne spp. on, cultivar susceptibility, S4.61

novel broad-spectrum resistance to potyviruses in, S4.120

Oncidium spp. on, in Russia, S4.64

Pectobacterium spp. on: coinfection with Verticillium dahliae and, S4.32; species associated with bacterial stem rot syndrome of in Canada, 937

Phytophthora infestans on: Alternaria grandis and, comparative epidemiology in Brazil, S4.32; genotype distribution in Canada in 2011, S4.62; molecular determinants of resistance activation and suppression by effector IPI-O, S4.22; oospore formation and, S4.44; phenotypic variation within a clonal lineage in Nicaragua, 323; potassium phosphite and, S1.5; tuber and foliage 
transcriptome dynamics, S4.42; USABlight and fungicide sensitivity of recent isolates, S4.106; weed hosts and aggressiveness of, 429

potato cyst nematodes on, dispersal measurement using historical and spatial statistical analyses, 620

Potato virus $H$ in, in China, S4.69

Potato virus $Y$ in: breeding for resistance, S4.148; as emerging problem in North America, S4.148; modeling aphid vector flights and, S4.148; predominance of Agata cultivar and, S4.97; as threat to other solanaceous crops, S1.4

Pratylenchus penetrans and Verticillium dahliae on, manipulating inoculum densities with green manure amendments and solarization, 519

review of large-scale field trials in, S4.152

Rhizoctonia solani on, in Idaho and Michigan, characterization and pathogenicity of isolates, $\mathrm{S} 4.135$

Streptomyces spp. on: S. scabies, fumigation and at-plant treatments for control of, S4.133; secondary metabolism and disease development, S4.158

Verticillium dahliae on: coinfection with $\mathrm{Pec}$ tobacterium spp., S4.32; disease development and, S6.9; incidence and impacts of in dirt associated with certified seed lots, S4.32; population biology of, S6.8

Solar radiation, Phakopsora pachyrhizi on soybean and, 794

SolaR80 system, for comprehensive survey of solanaceae R-gene space, S4.15

Solarization. See Soil solarization

Solhaug, K. A., S4.116

Solheim, H., S4.40

Solorzano, C., S2.9

Song, J., S4.69

Song, Z., 841

Songkumarn, P., S4.165

Sorbitol dehydrogenase activator. See SDA1

Sorghum bicolor

for bioenergy crop, response to grain and stalk fungal pathogens, S4.157

Colletotrichum sublineolum on, secondary metabolite genes and gene clusters of, S4.138

production practices and anthracnose severity and biomass yield of, $\mathrm{S} 2.5$

Sorghum mosaic virus (SrMV)

in maize, resistance conferred by Wsm loci to,

S4.114

real-time PCR for, S4.89

Sorur, A. Y., S4.112

Soto, C., S4.112

Soto-Arias, J., S4.112

Southern New England Grape Information Network

(SNEGIN), overview of, S1.3

Southern Pine Decline, impact of cogongrass on, S2.1

Southwood, M. J., 204

Souza, A. G., S4.112

Souza, E. A., 490

Souza, M., S4.11

Souza, P. E., S4.27

Soybean. See Glycine max

Soybean cyst nematode. See Heterodera glycines

Soybean target spot, assessment of damage in

2011/2012 in Brazil, S4.80

Soybean vein necrosis associated virus (SVNaV), in soybean, epidemiology of, S4.144

Soybean yellow shoot virus (SYSV), in soybean, in

Brazil, S4.44

Spadaro, D., S4.112

Spaine, P., S4.152

Sparks, A. H., S4.74, S4.113, S4.162

Spartina alterniflora

herbivory of purple marsh crab on, influence of

Fusarium palustre, drought, and DMSO, S4.34 purple marsh crab on, role of drought, flooding, and/or infection by Fusarium palustre on, S1.3 Spectroscopy. See Micro-Raman spectroscopy

Sphaerobolus stellatus, on turfgrasses, S4.8

Sphaeropsis pyriputrescens, on apple, PCR assays

for, S4.109

Sphaerotheca fusca, on watermelon

alternative spray schedule of fungicides and

potassium phosphonate for control of, S4.61

control using egg yolk and cooking oil, S4.61

Spiceland, D., S4.9

Spiers, J., S4.70

Spies, C. F., S4.113

Spies, C. J., S1.5

Spinach curly top Arizona virus (SCTAzV), as diver-

gent curtovirus arising from recombination, S4.52 Spinacia oleracea (spinach)

emergence of two highly divergent curtoviruses of, S4.52

Fusarium oxysporum f. sp. spinaciae on, effects of micronutrients and limestone amendment, S4.43

multiplex real-time PCR assay for soilborne pathogens of, S4.38

Peronospora farinosa $\mathrm{f}$. sp. spinaciae on, overview of resistance, $\mathrm{S} 4.26$

Verticillium dahliae and in four valleys in California, S4.48 on lettuce, 1071

on seed: in coastal California, S6.10; management of, S6.8; real-time PCR assay for detection and quantification of, 443

Spiroplasma citri, on citrus, incidence and spatial

temporal distribution, S4.141

SPLCV. See Sweet potato leaf virus

Spore-trapping

in Canada for monitoring of microbial phytopathogens in air and rain samples, S4.22

for early trapping of airborne inoculum from wind-disseminated oomycetes, S4.118

Sporisorium reiliana, on maize, qHS2.09 locus and, 692

Spurlock, T., S4.113

Spurlock, T. N., S2.9

SPVG. See Sweet potato virus $G$

Squash. See Cucurbita pepo

Squash vein yellowing virus (SqVYV)

in cucurbits, latent class analysis to estimate sensitivities and specificities of diagnostic tests for, $\mathrm{S} 4.122$

in watermelon, resistant pollinizers and, S4.65

SqVYV. See Squash vein yellowing virus

Srinivasa Rao, K., 222

Srinivasachary, S., S4.135

Srinivasan, R., S4.33, S4.113

Srivastava, M., S4.113

Srivastava, P., 794, S4.113, S4.114

SrMV. See Sorghum mosaic virus

sRNAs (small RNAs), detection of in Xylella

fastidiosa, $\mathrm{S} 4.22$

SSCTV-[AZ]. See Spinach severe curly top virus[AZ]

St. Amand, P., S4.86

St Martin, S. K., S5.5

Stacey, J. M., S4.24

Stack, J., S4.120

Stack, J. P., S4.27, S5.3

Stafford, C. A., S4.149

Staghorn sumac. See Rhus typhina

Stagonospora nodorum, on wheat

climate patterns as predictors of, S4.65

effects of foliar fungicides and application timing, S4.135

necrotrophic effector host-gene interactions and, 94

necrotrophic effectors and host sensitivities, 498

Stajich, J. E., S4.162

Stall, R. E., S4.45

Stamler, R. A., S4.114
Standardized area under the disease progress stairs (sAUDPS), 381

Stanghellini, H. G., S4.82

Stanosz, G. R., S4.111

Staskawicz, B. J., S4.148

Stasko, A. K., 539

Stead, S. E., S4.28

Steam disinfection, of Phytophthora ramorum from soil, S4.59, S4.60

Stefansson, T., S4.114

Steffenson, B. J., 683

Steger, A., S4.25

Steger, A. J., S2.3

Stein, J. M., S4.44

Steinlage, T. A., S4.100

Stenger, D. C., 32, S4.67

Stenocarpella maydis, on corn

mapping genes associated with resistance, S4.102 timing and efficacy of fungicide application, S5.8

Stenotrophomonas spp.

S. maltipholia, on citrus, in Iran, S4.3

S. rhizophila, on citrus, in Iran, $\mathrm{S} 4.3$

Stensvand, A., S4.7, S4.42, S4.116

Stephenson, A. G., S1.7

Stewart, J., S4.102

Stewart, J. E., S4.63

Stewart, L. R., S4.114, S5.7

Sthapit, J., S4.145

Stivison, A., S4.151

Stobbe, A., S4.114, S4.115

Stobbe, A. H., S4.155

Stocks, S. D., S4.54

Stoddard, S., S6.7

Stojšin, V. B., S4.115

Stoltzfus, J., S1.7

Stouthamer, R., 456

Stover, E., S4.31, S4.63

Strand, J. F., S4.91

Strausbaugh, C. A., S4.115

Strauss, J., S4.12

Strawberry. See Fragaria $\times$ ananassa

Strawberry necrotic shock virus (SNSV), TaqMan qPCR detection of, S4.53

Stream baiting, for Phytophthora ramorum, S2.1, S4.94

Stream monitoring, for Phytophthora ramorum in Louisiana, S4.94

Streett, D., S4.87

Strem, M. D., S3.4

Streptomyces spp.

on jalapeño pepper, electrophoretic profiles of peroxidases and polyphenol oxidases and, S4.46

S. lydicus

for management of Fusarium oxysporum $\mathrm{f}$. sp. niveum on watermelon, $\mathrm{S} 4.53$

for Pseudomonas syringae pathovars on sweet cherry, S4.2

on potato, secondary metabolism and disease development, S4.158

S. scabies, on potato, fumigation and at-plant treatments for control of, S4.133

Strobilurin fungicides, for Guignardia citricarpa on citrus, baseline sensitivity, S4.53

Strouts, W., S4.120

Stuffing cucumber. See Cyclanthera pedata

Stutt, R. O. J. H., 365

Subbarao, K. V., 443, 1071, S4.48, S4.77, S4.109, S4.160, S6.12

Subedi, A., S2.9, S4.115

Succinate-dehydrogenase-inhibitor (SdhI) fungicides, mechanisms of resistance of Botrytis cinerea to, S4.4

Sudarshana, M. R., S4.74, S4.156

Sudarshana, P., S4.115

Sudol, L. R., S1.7

Sugano, J. S., S1.6

Sugar beet. See Beta vulgaris

Sugarberry. See Celtis laevigata 
Sugarcane. See Saccharum spp.

Sugarcane mosaic virus (SCMV), real-time PCR for, S4.89

Sujatha, K., 222

Sulfur dioxide ( $\mathrm{SO}_{2}$ ), for control of Botrytis cinerea on blueberry, $\mathrm{S} 4.100$

Sumac, staghorn. See Rhus typhina

Summers, C. F., S4.115

Sumner, L. W., S4.123

Sun, J., S4.72

Sun, P., 779

Sundaraj, S., S4.113

Sundaram, R. M., 222

Sundaresan, V., S4.165

Sundelin, T., S4.35, S4.116

Sundin, G., S4.45

Sundin, G. W., S4.19, S4.64, S4.68, S4.79, S4.142,

S4.147, S5.6, S5.7, S5.8

Sunflower. See Helianthus spp.

Sunlight exposure

Erysiphe necator on grape and, 857

Phakopsora pachyrhizi on soybean and, 794

Suo, X., S4.143

Super-resistance, of Botrytis cinerea on strawberry, S4.4

Susceptible, exposed, infected, and removed (SEIR)

compartmental model, extension to, 365

Suslow, K., S4.90

Suthaparan, A., S4.116

Sutula, C., S4.143

Suzuki, H., S4.141

SVNaV. See Soybean vein necrosis associated virus

Sweany, R. R., S2.10

Sweeps, lagrangian stochastic models of spore

trajectories within plant canopy turbulence and, 1026

Sweet cherry. See Prunus avium

Sweet potato. See Ipomoea batatas

Sweet potato feathery mottle virus (SPFMV), in sweet potato, role of virus titer and aphid species population abundance in spread of, S4.138

Sweet potato leaf virus (SPLCV-PR), in Merremia

spp., in Puerto Rico, S4.51

Sweet potato virus 2 (SPV2), in sweet potato, role of virus titer and aphid species population abundance in spread of, $\mathrm{S} 4.138$

Sweet potato virus $G$ (SPVG)

in Ipomoea setosa, $\mathrm{S} 4.130$

in sweet potato, role of virus titer and aphid species population abundance in spread of, S4.138

Sweetpotato feathery mottle virus (SPFMV), in sweet

potato, host plant, aphid species and virus infection status, S2.11

Sweets, L., S4.102, S5.8

Sweigard, J. A., S4.55

Swett, C. L., S4.116

Swett, . L., S6.13

Switchgrass. See Panicum virgatum

Swoboda, G., S4.117, 160

syrF and syrG regulatory network, Pseudomonas

syringae pv. syringae B728a on bean and, S4.126

Sysak, R. W., S4.106

Systemic acquired resistance (SAR)

control of Phytophthora capsici on tomato and, S4.80

huanglongbing, acidbenzolar-S-methyl and, S4.47 microbial competitive exclusion, biological control and, 260

SYSV. See Soybean yellow shoot virus

Syzygium aromaticum (clove), Meloidogyne entero-

lobii on, in China, S4.37

Szabo, L. J., S4.117, S4.157

Szostek, S., S4.117

Szurek, B., 948

T6SS. See Type VI secretion system (T6SS)

Tabima, J., S4.18, S4.117

Tada, Y., 741

Taddei, A. R., 827
Taghinasab Darzi, M., S4.3, S4.117

TAL effector nucleases (TALENS), for targeted genetic modification, S4.151

TAL effectors

Xanthomonas citri subsp. citri on citrus and, $\mathrm{S} 4.55$

Xanthomonas oryzae on rice and, S4.127

Talas, F., 128

Talledo, M., S4.118

Tally, A., S4.88

Tamborindeguy, C., 41, S6.4

Tanacetum cinerariifolium (pyrethrum)

integrated management of diseases of in spring, S4.92

Phoma ligulicola on, taxonomic reassessment of, S4.125

Tancos, M. A., S4.118

Tandem repeat number variation, Candidatus Liberi-

bacter asiaticus population diversity in China and S4.74

Tang, X., S5.3

Tang, Y., S4.51

Tangerine. See Citrus tangerina

Taniguchi, M., S4.23

TaqMan RT-PCR, for viruses in grapevine, S4.82

Taro. See Colocasia esculenta

Tart cherry. See Prunus cerasus

Tatalovic, N., S4.118

Tatineni, S., S4.42, S4.118, S4.134

Taylor, C. G., S5.9

Taylor, C. T., S4.31

Taylor, P. W., S4.125

Taylor, R. K., 1034

TBSV. See Tomato bushy stunt virus

TCDVd. See Tomato chlorotic dwarf viroid

TCSV. See Tomato chlorotic spot virus

TeBeest, D. O., S2.6

Tedford, E. C., S4.152

Teeratananon, A., S4.28

Tef-1a locus, phylogenetic relationships among north-

ern hemisphere Armillaria spp. and, S4.63

Teixeira, H., S4.112

Telfer, K., S4.116

Telles, N., S4.124

Telone II, for cotton nematodes, nitrogen rate and, $\mathrm{S} 2.5$

Temperature

Alternaria leaf spot and black spot on basil and, S4.94

ascocarp formation by Podosphaera aphanis on strawberry and, S4.7

Botryosphaeria dothidea and Diplodia seriata on blueberry and, S4.111

Candidatus Liberibacter solanacearum gene expression and, S4.164

Colletotrichum spp. on olive and, 974

colonization of Guignardia psidii on guava and, S4.25

Fusarium graminearum perithecial development on the straws decomposed in different soils, S4.115

Fusicladium carpophilum on nectarine and, 421

Neofusicoccum parvum on blueberry and, S4.34

Phakopsora pachyrhizi on soybean and, 761,

S4.13

Puccinia graminis subsp. graminis f. sp. tritici on wheat, effect on latent period across isolates from different cultivars, S4.52

Ralstonia solanacearum and adaptation of, S4.56 on tobacco, host resistance and, $\mathrm{S} 4.12$ virulence of, 185

Rhynchosporium commune adaptation and, S4.114

risk of disease in grapevine and other perennial crops and, S4.42

virus titer development and population growth of the wheat curl mite in wheat streak-resistant wheat cultivars and, S4.94

Temple, K., S4.22
Temsah, M., S4.104

Teplitski, M., S4.9

Terrorist, FBI and attacks on U.S. food or agriculture, S4.163

Terry, A., S6.4

Testen, A. L., S1.7, S4.118

Texas Phoenix palm decline, phytoplasmas associated with, S6.2

Textual surveillance data, unified concepts of disease in, S4.161

TGB proteins. See Triple gene block (TGB) proteins

Thammarat, P., S4.119

Thatch collapse, as new disease of golf course turfgrasses, S4.8

Thaveechai, N., S6.5

Thekke Veetil, T., S4.119

Thekopsora minima, on blueberry, in Michigan, S4.106

Theobroma cacao (cacao), Moniliophthora spp. on M. perniciosa, $\mathrm{S} 4.88$ $M$. rore, $\mathrm{S} 3.4$

Theron, J., S4.109

Thiabenzole, for Penicillium spp. on apple, development of resistance to, $\mathrm{S} 4.43$

Thies, J. A., S4.119

Thiessen, L. D., S2.10

Thiophanate methyl, Sclerotinia sclerotiorum resistance to, S5.1

Thomas, C. S., S4.161, S6.13

Thomas, S., S4.50, S4.115

Thomma, B. P., S4.77

Thompson, A. A., S4.119

Thompson, J., S4.92

Thompson, J. R., S4.65

Thon, M. R., S4.120

Thousand cankers disease

genetic diversity in southeastern U.S., S4.49

on walnut

distribution and impact in western U.S. S4.158

pathologist's perspective on in eastern U.S., S4.158

progression in Tennessee in 2010-2011, S3.3 as recently emerging disease in eastern U.S., S4.159

Thrips, western flower. See Frankliniella occidentalis

Thrips tabaci (onion thrips)

acquisition and transmission of Pantoea ananatis and Pantoea agglomerans by, S4.33

Iris yellow spot virus and, seasonal dynamics, S4.8

overwintering, as source of Iris yellow spot virus, S4.117

Ti. See Cordyline fruticosa

Tian, G., 413

Tian, L., S4.80

Tian, M., S4.119

Tianjingyeshengdao rice cultivar, Magnaporthe oryzae on, mapping resistance genes of, 779

Tillage system, Rhizoctonia-bacterial root rot complex in sugar beet and, S4.115

Tillman, B. L., S2.2, S2.8, S4.151

Time scales, of inoculum production and dynamics of epidemic, 728

Timmerma, A., S5.2

$\mathrm{TiO}_{2} / \mathrm{Zn}$, for control of Xanthomonas perforans on tomato, S4.89

Tisserat, N., S4.113, S4.158

Tisserat, N. A., S5.2

Tissue-print methods, for detection of Citrus tristeza virus, 122

TOANV. See Tomato apex necrosis virus

Tobacco. See Nicotiana spp.

Tobacco etch virus (TEV) in bell pepper, strains inducing different disease phenotypes, S4.84 comparison of three strains, $\mathrm{S} 4.127$ in pepper, isolate overcoming two resistance genes, S4.127 
Tobacco streak virus (TSV), TaqMan qPCR detection of, S4.53

Todd, C. E., S4.119

Todd, T. C., S4.69

TofI/TofR quorum sensing system, Burkholderia glumae on rice and, S2.2

tof $M$, quorum sensing-independent biosynthesis of toxoflavin in Burkholderia glumae and, S4.22

Tohamy, A., S4.120

ToLCSDV. See Tomato leaf curl Sudan virus

Tolin, S. A., S4.151

Tolumnia spp., identification and characterization of soft-rot pathogens isolated from, S4.19

Tomaso-Peterson, M., S2.5, S2.10, S4.45, S4.111, S4.120

Tomato. See Solanum lycopersicum

Tomato apex necrosis virus (ToANV), in tomato, genetic diversity and whitefly transmission, S4.37

Tomato bushy stunt virus (TBSV)

in lettuce, environmental factors and disease development, S4.136

in Nicotiana spp., hypersensitive response and, S4.5

Tomato chlorotic dwarf viroid (TCDVd), in tomato,

in Arizona, biological and molecular characterization of, S4.139

Tomato chlorotic spot virus (TCSV), Groundnut ringspot virus and, thrips transmission of virus reassortment, $\mathrm{S} 4.133$

Tomato leaf curl Sudan virus (ToLCSDV), in tomato, molecular characterization of, S4.56

Tomato necrotic stunt virus (TNSV), in tomato, in

Mexico, S4.70

Tomato psyllid. See Bactericera cockerelli

Tomato ringspot virus (ToRSV), multiplex RT-PCR for identification of, S4.20

Tomato spotted wilt virus (TSWV)

differential acquisition and transmission by Western flower thrips, S4.98

Frankliniella occidentalis feeding behavior and,

S4.149

in peanut

identification of putative resistance genes, S2.3

identification of putative resistance genes,

development of gene-specific markers, and integration to genetic linkage group, S4.37 improvements in field resistance, $\mathrm{S} 2.2$ resistant genotypes and interactions with thrips, S4.113

synergistic interaction with Iris yellow spot virus, S6.8

in tomato

degree-day model to predict thrips growth and development of, S4.19

insecticide programs for in California, S4.122

Tomimatsu, G. S., S4.154

Tomlinson, A., S4.85

ToNSV. See Tomato necrotic stunt virus

Toomajian, C., S4.120

Toome, M., S4.103

Toothpick baiting method, for Rhizoctonia solani on zoysiagrass, S6.4

Torrance, L., S4.120

Torre, S., S4.116

Torres, M. F., S4.17, S4.138

Torres, R., S4.34

Torres Quintero, M. F., S4.120

Torres-Acosta, J., S4.146

ToRSV. See Tomato ringspot virus

Tosa, Y., 674

Toubia-Rahme, H., 683

Tourvieille de Labrouhe, D., 908

Toxin-antitoxin system, Xylella fastidiosa growth and, S4.67

Toxins, Ascochyta rabiei on chickpea and, S4.64

Toxoflavin, quorum sensing-independent biosynthesis of in Burkholderia glumae, S4.22

Trade concerns, WTO's SPS Agreement and, S4.163

Trail, F., S4.147

Traini, A., S4.15
Tran, T. M., S4.121

Transcriptional Activator-Like effectors. See TAL effectors

Transcriptome analysis

of Armillaria solidipes, candidate pathogenicityrelated genes, S4.102

of Begomovirus-whitefly transmission, S4.164 of Colletotrichum graminicola on maize, S4.120

of CYP83B1 during Alternaria spp. infection in cauliflower, S4.108

of Fusarium spp., S4.48

of Phytophthora infestans on potato, S4.42

of Sclerotinia sclerotiorum on chickpea and lentil, S4.95

of Sclerotinia trifoliorum on chickpea, S4.95

Transgenic crops, serological tests of, S4.51

Transportation grids, as early indicators and

warnings, S4.161

Trapa natans (European water chestnut), plant pathogens of, S1.2

Trapero, A., 974, 982

Traquair, J. A., S4.121

Travis, J. W., S4.49

Trebicki, P., S4.157

Tredway, L., S4.95

Tredway, L. P., S1.1

Tree tomato. See Solanum betaceum

Trehalose, estimating viability of potato cyst nema-

todes and, 140

Trejo, R., S4.50

Trelles, A., S4.118

Trenching, for prunus replant disease, S4.93

Trialeurodes vaporariorum, $\mathrm{mtCOI}$ primers for the

rapid identification of, $\mathrm{S} 4.5$

Trichoderma spp.

for control of Phoma exigua var. exigua and Phytophthora cryptogea on chicory, S4.81

T. harzianum, strain ETS 323, antagonism on Botrytis cinerea mycelium in culture conditions, 1054

T. virens, role of gliotoxin in, $\mathrm{S} 6.3$

Trichodiene synthase (Tri5), mycotoxin synthesis by

Fusarium graminearum and, S4.146

Trichothecenes

Fusarium graminearum on wheat and barley and, S4.146

mitochondrial translocation and, S1.2

Trick, H. N., S4.69

Trifloxystrobin, for Venturia inaequalis on apple,

real-time PCR for detection of resistant strain,

S4.128

Trigiano, R., S4.70

Trigiano, R. N., S2.3, S4.36, S4.49

TriMV. See Triticum mosaic virus

Trinexapac-ethyl, Sclerotinia homoeocarpa on

turfgrasses, fungicide efficacy and, S4.56

Tringe, S., S4.159

Trinh, S. A., S4.37, S4.139

Trinidad, E., S4.118

Tripathi, D., S4.121

Triple gene block (TGB) proteins

Alternanthera mosaic virus replication and, S4.85

Barley stripe mosaic virus and, S4.69

Triplett, L., S4.127

Triplett, L. R., S4.19, S4.121, S4.158

Triticale, Magnaporthe grisea on, pathogenic, mating

type, and population structure of, S4.124

Triticum aestivum (wheat)

deoxynivalenol and Fusarium diseases of, identification of candidate resistance genes, S4.146

deoxynivalenol concentration in primary spikes and tillers of, S4.44

Fusarium spp. on

Fusarium head blight and: cost-benefit assessment of integrated management strategies for, S5.8; Cryptococcus flavescens for control of, S5.8; integrating grain harvesting and preharvest management strategies to minimize losses due to, S4.105
F. graminearum: association analysis to detect regions of genome conferring resistance, S5.5; associations between the timing of fungicide application and percent control, S4.28; atmospheric patterns and, 55; characterizing heterogeneity of disease incidence in a spatial hierarchy, 867 ; withinfield variation in aggressiveness and DON production, 128; influence of moisture pattern on deoxynivalenol contamination, $\mathrm{S} 4.5$ soil moisture and temperature and, S2.9; trichothecenes and, S4.146; variation for resistance to kernel infection and toxin accumulation, 306

molecular identification of species and chemotypes, S4.134

Magnaporthe oryzae on

as emerging threat, S5.3

probability of introduction into United States, S4.27

marker-assisted breeding for disease resistance in, 560

PR-1 proteins of, heterologous expression and functional analysis of, S4.33

Pseudomonas fluorescens and defense gene induction in, S6.10

Puccinia spp. on

$P$. graminis f. sp. tritici: differential expression of the pathogenesis-related protein 1 $(P R-1)$ gene family and, S4.73; high-resolution mapping of Ug99 resistance gene from, S4.145

P. graminis subsp. graminis f. sp. tritici, effect of temperature on latent period of isolates across different cultivars, $\mathrm{S} 4.52$

$P$. striiformis: boosted regression trees to evaluate effect of drought indices and local weather conditions, in Kansas, S4.47; in United States in 2011, S4.130

P. striiformis f. sp. tritici: managing in soft red winter wheat, $\mathrm{S} 4.81$; temperature shifts and resistance, $\mathrm{S} 4.16$

P. triticina, histological characterization of wheat pre-and post-haustorial resistance components, S5.4

P. triticina f. sp. tritici, Aegilops tauschii as a source of adult plant resistance to, S4.61

Pyricularia oryzae on, biochemical changes in leaves, 1121

Rhizoctonia solani on, natural suppression by soil microbial communities at decline site, S4.141

seed of, chlorine dioxide for disinfection of, S4.59

Septoria tritici on, epidemiology and management in Ontario, S4.17

Stagonospora nodorum on

climate patterns as predictors of, S4.65 effects of foliar fungicides and application timing, S4.135

necrotrophic effector host-gene interactions and, 94

necrotrophic effectors and host sensitivities, 498

Triticum mosaic virus in

effect of single and double infections on grain yield and yield components, S4.134

occurrence and distribution in central Great Plains, S5.2

Wheat streak mosaic virus in, effect of single and double infections on grain yield and yield components, S4.134

Xanthomonas campestris pv. translucens on effect of inoculation method, inoculum concentration, and plant growth stage on infection development, S4.61

relationship between greenhouse and field reactions to, $\mathrm{S} 5.5$ 
Triticum mosaic virus (TriMV)

genetic evidence for recent population expansion and balancing selection, $\mathrm{S} 4.42$

in wheat

effect of single and double infections on grain yield and yield components, S4.134

occurrence and distribution in central Great Plains, S5.2

Trivedi, P., S4.12

Tronsmo, A., S4.7

Tropiano, R., S4.12

Trypsin inhibitors, from Inga laurina, for control of

Diatraea saccharalis and Heliothis virescens, S4.97

Tsae, P. K., S1.8

Tsai, W., S4.122

Tseng, H., S4.122

TSV. See Tobacco streak virus

TSWV. See Tomato spotted wilt virus (TSWV)

Tu, Z., S4.42, S4.105

Tubajika, K. M., S4.122

Tubakia spp. on, on oak, S4.142

Tumer, N., S1.2, S1.8

Tunali, B., S3.1

Turechek, W., S4.65, S4.122

Turechek, W. W., S4.133

Turfgrasses. See also Specific grasses

Magnaporthe oryzae on, GFP-tagged, S4.69

Sclerotinia homoeocarpa on

influence of dew removal methods and plant

growth regulators on fungicide efficacy for the control of, S4.56

molecular detection and host adaptations,

S4.7

species boundaries between members of the

Sclerotiniaceae and Rutstroemiaceae, , S1.1

Sphaerobolus stellatus on, S4.8

strobilurin fungicide applications and, plant health benefit of, S4.11

thatch collapse as new disease of, S4.8

Waitea circinata var. circinata on, microsatellite

markers and clinical expansion of, S1.6

Turini, T., S6.7

Turini, T. A., S4.122

Turner, A. N., S4.16

TVE. See Tobacco etch virus

Twizeyimana, M., S4.35, S4.122, S4.123

Twomey, M. C., S4.137

Tylka, G. L., S4.9, S4.118

Tymovirus, molecular characterization, ecology, and

epidemiology of in Asclepia viridis, 166

Type III secretion system (T3SS)

Burkholderia glumae on rice and, S4.148

in Erwinia amylovora

inhibitors and inducers of, S4.63

translocation of effector proteins and,

S4.19

necrotic pathogens and, S4.147

of Pseudomonas syringae, $\mathrm{S} 4.165$

Type VI secretion system (T6SS), in Pantoea

ananatis, bacterial competition and, S4.109

Tzanetakis, I., S2.11, S4.144

Tzanetakis, I. E., 1182, S2.7, S4.53, S4.119

Uauy, C., S4.16

Ubiquitination, Magnaporthe oryzae growth, develop-

ment, and pathogenicity and, S4.87

Uchoa, C. N., S4.27

Uddin, W., S1.5, S4.7, S4.69, S4.96

Ugg99 resistance gene, from Puccinia graminis f. sp.

tritici on wheat, high-resolution mapping of Ug99,

S4.145

Universal Plant Virus Microarray (UPVM)

development and validation of, S4.155

progress in development of, S4.49

Unmanned aerial vehicles (UAV), Fusarium spp.

recovery using, S3.4

Uppala, S., S4.123

Uppalapati, S., S4.123

Uppalapati, S. R., S4.157
UPVM. See Universal Plant Virus Microarray;

Universal plant virus microarray (UPVM)

Urashima, A., S4.13, S4.124

Urbez Torres, J. R., S4.124

Uribe, P., 331

Uromyces spp

$U$. appendiculatus, on common bean, genetic analysis of broad-spectrum resistance, $\mathrm{S} 4.90$

U. graminicola, on switchgrass, DNA barcodes for identification of, S4.89

T. harzianum, foliar leachate of Vicia villosa and growth rate of, $\mathrm{S} 3.3$

U. transversalis, on gladiolus, fungicides for management of, S4.125

US Nursery Certification (USNCP), incidence of five

common pests in nurseries participating in, S4.89

USABlight, Phytophthora infestans on potato and,

S4.106

Usami, T., S4.125

Ustilaginoidea virens, on rice

effective management strategies for, S2.6

field evaluation of fungicides for control of, S4.144

Ustilago maydis, on corn, virus-mediated protection, S4.151

UV-B irradiation, Podosphaera xanthii on cucumber and, S4.116

UV-C irradiation, and resistance of Arabidopsis

thaliana against Hyaloperonospora arabidopsidis, S4.81

Vaccines, attenuated Pepino mosaic virus strain as, S5.3

Vaccinium spp.

V. corymbosum (blueberry)

black shadow disease on, $\mathrm{S} 1.8$

Blueberry necrotic ring blotch virus in, $\mathrm{S} 4.17$, S4.101

Botryosphaeria dothidea and Diplodia seriata on, effects of temperature on infection and lesion development, S4.111

Botrytis cinerea on, sulfur dioxide for control of, S4.100

Colletotrichum acutatum on, host defenses, inheritance of resistance, and environmental effects, S4.150

Diaporthe spp. on, in Chile, pathogenicity of, S4.34

Fusarium incarnatum- F. equiseti species complex on, in Argentina, S4.91

Monilinia vaccinii-corymbosi on: population genetics in United States, S4.17; propiconazole resistance and, S4.119

Neofusicoccum parvum on, influence of temperature on canker development, S4.34 phytoplasmas associated with stunt disease on in New Jersey, S4.8

Thekopsora minima on, in Michigan, S4.106

Xylella fastidiosa on, xylem hydraulic conductance and field resistance, S4.54 yeasts of, preliminary survey of and potential for disease control, S4.121

V. oxycoccos cranberry, Phomopsis vaccinii and

Fusicoccum sp. on, S4.19

Váczy, K. Z., 707

Váczy, Z., 707

Vaghefi, N., S4.125

Vahling-Armstrong, C. M., S4.125

Vaillancourt, L., S4.17

Vaillancourt, L. J., S4.120, S4.138

Valdebenito-Sanhueza, R., S4.125

Valdivia, C., S4.45

Vale, F. X., S4.82, S4.101

Valencia-Botín, A. J., S4.125

Valent, B., S4.165, S5.3

Vallad, G., S4.89

Vallad, G. E., S4.2, S4.139

Valverde, R., S4.126

Valverde, R. A., S4.104

van Asseldonk, M., 609
Van Bruggen, A. H., S4.23, S4.99, S4.126

van Bruggen, A. H., S4.48

van Bruggen, A. H. C., 413

van den Bosch, F., 365, S4.53, S4.54

van den Elsen, S., 140, 1153

van der Puije, G. C., S4.126

van Doorn, J., 1153

Van Helden, M., 627

van Heusden, A. W., S4.37

van Lent, J. W., S4.44

van Loon, L. C., 403

van Pelt, J. A., 403

van Ryzin, B., S4.100

van Wijk, K., S4.119

vanBruggen, A. H., S4.35

Vance, V., S4.165

Vanda spp., identification and characterization of

soft-rot pathogens isolated from, S4.19

Vandemark, G., S4.95

VanKirk, J., S4.107

Vanneste, J. L., 1034

VanOverbeke, M., S4.47

Vargas, J., S4.33

Vargas, J. M., S4.45

Vargas, W., S6.3

Variable numbers of tandem repeats (VNTR), for

detection of Xanthomonas oryzae pv. oryzicola on rice, 948

Varma, Y., S4.126

Varsani, A., S4.52

Vasquez, S. J., 652, S4.89

Vaughn, V. L., S4.126

Vea, E., S1.6

Vectors

ecological and molecular basis of competence, S4.149

manipulation of host-derived olfactory cues by vector-borne pathogens of plants and insects, S4.150

molecular basis of competence in mosquito-arbovirus interactions, $\mathrm{S} 4.150$

strategies employed by animal parasites to enhance transmission of, $\mathrm{S} 4.150$

Veenhuizen, P., 1153

Vega, B., S4.127

Vegetables, Ralstonia solanacearum on, comparison with strains from tobacco, S4.122

VEGEVADERS game, $\mathrm{S} 4.2$

Velasquez, N., S4.127

Venter, S. N., S4.29, S4.109

Venturia inaequalis

on apple, real-time PCR for detection and quantification of trifloxystrobin-resistant strain, S4.128

development of qualitative resistance to the QoI fungicide trifloxystrobin in regional populations of, S4.42

dodine resistance in northeastern US populations after renewed use of Syllit for apple scab management, S4.26

orchard factors associated with resistance and cross resistance to sterol demethylation inhibitor fungicides in, 272

role of CYP51A1 overexpression in myclobutaniland difenoconazole-resistant strains, S4.128

Verdier, V., 948, S4.127

Verkley, G. J., S4.167

Verma, R., S4.155

Verstappen, E., 635

Verticillium spp.

on alfalfa and flax, diagnostic assay for, S4.12

allelic variation in effector gene Ave1 among,

S4.77

V. dahliae

on chili pepper: examination of race structure in New Mexico, S4.50; screening for biocontrol agents for, S4.50

in fields of coastal California, S6.10 genetic diversity and population biology of global collection, S4.109 
on lettuce, sources of, 1071

on mint: disease development and, S6.9; population biology of, S6.8

on potato: coinfection with Pectobacterium spp., S4.32; commercial-scale soil test data and, S4.45; disease development and, S6.9; incidence and impacts of in dirt associated with certified potato seed lots, S4.32; manipulating inoculum densities with green manure amendments and solarization, 519; population biology of, S6.8

in production fields of ornamental nursery industry, S6.13

race 2 , on tomato, grafting for management of, S4.57

on spinach, in four valleys in California, S4.48

on spinach seed: in coastal California, S6.10; management of, S6.8; real-time PCR assay for detection and quantification of, 443 on strawberry: assay for rapid detection and quantification in soil, 331; management with and without fumigation, S6.9

on lettuce, 1071, S6.12

$V$. longisporum, as hybrid pathogen with expanded host range, $\mathrm{S} 4.160$

$V$. nonalfalfae, on Ailanthus altissima, risk analysis for, $\mathrm{S} 4.62$

Vervoort, M., 1153

Veturi, Y., 1016

Viability, of potato cyst nematodes, assay for estimation of, 140

Vico, I., S4.43, S4.58, S4.92, S4.127

Vidal, E., 114

Vidalakis, G., S4.131

Vieira, P., 990

Vigna radiata (green gram), Macrophomina phaseolina on, synergistic effects of arbuscular mycorrhiza, Glomus constrictum, nitrogen fixing bacteria Rhizobium sp. and, S4.85

Vigna unguiculata (cowpea), insecticidal plants and organic flowers as inert carriers in controlling, S4.88

Viljoen, A., 204

Villamor, D. V., S4.2, S4.128

Villani, S., S1.3

Villani, S. M., S4.26, S4.128

Villanueva-Alonzo, H. J., S4.83

Villate, L., 627

Vinatzer, B. A., S4.160

Vines, P., S2.10

Vines, P. L., S4.128

Vintila, S., 878

Viraktamath, B. C., 222

Virus-induced gene silencing (VIGS), Euphorbia mosaic virus Yucatan Peninsula derived vector in tobacco and, $\mathrm{S} 4.83$

Vitis spp. (grape)

Agrobacterium vitis on, magnetic capture hybridization and real-time PCR of, S4.59

Botrytis cinerea on comparative analysis of techniques for detection of, S4.104 prebloom leaf removal for control of, S4.52

comparison of methodologies used for the detection of viruses in, $\mathrm{S} 4.82$

DNA macroarray for detection of fungal pathogens involved in the decline of, S4.124 effects of vector pressure, natural infectivity, and host recovery on disease spread in, S4.47

Erysiphe necator on adaptation to heat stress in, S4.24 addressing uncertainty in epidemiology, S4.25 development and control under different levels of ascosporic inoculum dose, S4.83 effects on sunlight exposure on, 857 linkage disequilibrium and spatial aggregation of genotypes in sexually reproducing populations of, 997 modeling uncertainty in, S6.8

race-specific host resistance in North America, 83

sanitation and disease modeling for, $\mathrm{S} 4.68$

VitisGenPM for phenotyping of, S4.18

Grapevine fanleaf virus in

control by fallow plants, 627

large satellite RNAs associated with, S4.46

Grapevine fleck virus in, in Virginia, S3.3

Grapevine leafroll-associated viruses in grape mealybug ecology and, S6.13 in Virginia, S3.3

Guignardia bidwellii on, weather-based fungicide application advisor for, S4.111

interactions between winter chilling, asynchro-

nous crop phenology, ontogenic resistance, and the risk of disease, $\mathrm{S} 4.42$

mealybugs on, foliar insecticidal treatments for, S3.3

multiplex detection of viruses infecting, S4.92

Phaeomoniella chlamydospora on

in Chile, S4.29

colonization of fluorescent, 290

Plasmopara viticola on

G143A mutation and resistance to stroliburinclass fungicide, $\mathrm{S} 4.23$

mode of host resistance to, 1094

rain and dispersal of primary inoculum of, 158

rainfastness of fungicides on leaves, S4.106

survey of viruses present in, in Idaho, S4.61

sustainable pest management using weather data

and disease risk models, S4.91

virus diversity in Washington State Concord

vineyards, S4.9

viruses and viroids in, in Washington state, S4.98

Xylella fastidiosa on

alteration of phenolic compounds in xylem sap and tissues during infection with, 816

cell surface LPS and biofilm formation and virulence of, S4.147

control of disease with benign strain of, $\mathrm{S} 4.55$ phoP/Q two-component regulatory system and, S6.11

RpfF-dependent regulon of, 1045

shifts in secondary metabolic profiles during infection, S4.129

VitisGenPM, precision phenotyping center for powdery mildew resistance breeding in grapevine, S4.18

Vito, L., S4.128

Vito, L. M., S4.49

Vittal, R., 1143, S4.128

VNTR. See Variable numbers of tandem repeats

Volatile organic compounds (VOC)

from Ceratocystis fimbriata, growth of soilborne Rhizoctonia solani and rice seed germination and, S4.70

for control of Colletotrichum coccodes on stored potato, S4.135

from Fusarium oxysporum, growth and defense of Arabidopsis thaliana and, S4.12

of London rocket and flixweed, inhibitory effect of volatiles of on soilborne pathogens of chili pepper, S6.12

Phytophthora nicotianae on citrus and, S4.99

von Dahl, C., S4.119

Vrient, A., S4.143

$\mathrm{Vu}$, A. L., S2.3, S4.36

Vy, T. T. P., 674

Vyas, M., S4.164

Waalwijk, C., S4.11

Wade, L., S4.2, S4.129, S6.10

Wadl, P. A., S2.3, S4.36, S4.49

Waggoner, J., S6.1

Wagle, S., S2.8

Wahba Foreman, A., S4.165

Waitea circinata var. circinata, on turfgrasses, microsatellite markers and clinical expansion of, S1.6
Wakefield, L. M., 65

Walch, E., S5.1

Walcott, R., S2.10

Walcott, R. R., 461

Walker, D. R., S2.4, S4.150

Walker, N., S4.39

Walkinshaw, C. H., S4.129

Wall, G., S4.129

Waller, T. J., S1.8

Wallis, C., S4.129

Wallis, C. M., 816

Wallon, T., 967

Walls, J., S2.6

Walnut. See Juglans spp.

Walsh, D. B., S4.9

Walsh, E., 1016, S4.130, S5.9

Walter-Peterson, H. C., S3.2

Wan, A., S4.130, S4.132

Wang, B., S4.162

Wang, D., 779, S4.5, S4.16, S4.49, S4.130, S4.131,

S4.141, S4.155, S5.6

Wang, D. H., S4.35, S4.123

Wang, G., S4.165

Wang, G.-L., 779

Wang, H. C., 267

Wang, I., S4.131

Wang, J., 692, S4.130, S4.131, S4.132

Wang, L., S4.142

Wang, M., S4.130, S4.132

Wang, M. S., 267

Wang, N., 1045, S4.55, S4.58, S4.64, S4.121,

S4.130, S4.131, S4.140, S4.141, S4.147

Wang, Q., S4.131

Wang, R., S4.3, S4.143, S5.9

Wang, S., S4.84

Wang, Y., 779, S4.59, S4.132

Wang, Y.-G., 1064

Wang, Z., 692, 779

Wang-Pruski, G., S1.5

Wanyera, R., S4.145

Ward, L. J., 937

Ward, N. A., 749, S4.107

Warner, A., S4.112

Warr, M. R., S4.132

Warren, J., S6.13

Watanabe, S., S4.16, S4.132

Water. See also Irrigation water Phytophthora ramorum in, S2.1, S4.94

Salmonella enterica in, S4.99, S4.126

Watermelon. See Citrullus lanatus

Wavelet analysis, for spatial and temporal analysis of epidemics, S4.65

Wayadande, A., S4.5

Weather conditions. See Climate conditions, predicting aflatoxin in peanut and, S4.14

Weaver, M., S2.9

Weaver, M. A., S4.1, S4.133

Webb, K., 908

Weber, B. N., 214

Webster, B. J., S4.133

Webster, C., S4.122

Webster, C. G., S4.65, S4.133

Wechter, W., S4.133

Weeds

as alternate hosts for for Phytophthora infestans on potato, 429

as alternate hosts for Phytophthora infestans, S4.107

Phytophthora infestans on, oospore formation and, S4.44

survival of Colletotrichum acutatum on, S4.41

Weems, J. D., S4.133

Wegulo, S., S4.134

Wegulo, S. N., S4.42, S5.2

Wei, G., S4.24, S4.103

Wei, W., S4.143

Weiland, J., S4.43, S6.13

Weiland, J. J., S4.33

Weimer, J., S4.84 
Weinthal, D., S4.20

Weir, B. S., 1034

Weller, D. M., 403

Welliver, R. A., S4.154

Wells, C. E., 804

Wells, L., S4.134

Welsh, M., S4.93

Wen, A., S4.71, S4.134

Wen, J., S4.130

Wen, L., S4.134

Wen, X., S4.74

Weng, J., 692

West, E. D., S4.134

West, J., S4.19

West Indian fruit fly. See Anastrepha obliqua

Westerdahl, B. B., S4.135

Western flower thrips. See Frankliniella occidentalis

Wetness duration, Colletotrichum spp. on olive and 974

Wharton, P., S4.135

Wharton, P. S., S4.36

Wheat. See Triticum aestivum

Wheat curl mite, effect of temperature on growth of

in wheat streak-resistant strains, S4.94

Wheat streak mosaic virus (WSMV)

effects of temperature on virus titer development and population growth of the wheat curl mite in resistant cultivars, $\mathrm{S} 4.94$

functions of coat protein in virion assembly and virus movement, $\mathrm{S} 4.118$

in wheat, effect of single and double infections on grain yield and yield components, $\mathrm{S} 4.134$

Whigham, E., S4.142

Whitaker, V., S4.107

White, F. F., S4.55

White leaf phytoplasma, in sugarcane, seed trans-

missibility of, S4.76

White oak. See Quercus alba

White pine. See Pinus strobus

White pine needle damage (WPND), in New

England, S4.84

Whitefly. See Bemisia tabaci

Whitfield, A., S4.149

Whittington, H., S4.72

Whole genome sequences, identification of novel

markers from, S4.113

Wick, R. L., S1.4

Wicker, E., 733

Wickramasinghe, D., S5.9

Widmark, A.-K., 323

Widmer, T. L., S4.60

Wiecko, A., S4.129

Wiest, A., S4.167

Wilcox, W. F., 857, S4.42, S4.83, S4.104

Wild tomato. See Solanum lycopersicoides

Wilen, C. A., S4.135

Wiley, G., 166

Willi, Y., S4.114

Williams, W. P., 787

Williamson, K., S3.4

Willie, K., S5.7

Willis, D., S4.25

Willis, R., S4.2

Willocquet, L., S4.135

Willyerd, K., S5.8

Willyerd, K. T., S4.5, S4.28, S4.105, S4.135

Wilson, A., S4.136

Wilson, D. L., S4.61

Wilson, R., S1.8

Wilson, V., 908

Windels, C. E., S4.16, S4.136

Windham, A., S4.70

Windham, G. L., 787

Windham, M. T., S4.49

Winter, H., S4.136

Wintermantel, W. M., S4.136

Wise, C., S1.8

Wise, K., S4.152, S5.8

Wise, K. A., S4.102, S4.135, S5.8
Wisotsky, S., S2.10

Wisotsky, S. R., S4.90

Wisser, R. J., 1016

Wistrom, C. M., S6.13

Witte, A., S4.10

Woeste, K., S4.57

Wolf, T. K., S3.2

Wolfenbarger, S. N., S4.137

Woloshuk, C. P., S4.102, S5.8

Wong, B. C., S4.139

Wong, F. P., S1.6

Wonni, I., 948

Wood, relative potential of major root-rot and bolerot fungi to decay, S4.136

Wood, B. W. S4.13

Wood, D. L., S5.3

Wood, E., S4.135

Woodhall, J., S4.135

Woods, J. L., S4.137

Woodward, J. E., S2.10, S2.11

Worapong, J., S4.137

Workneh, F., 1079, S4.137

World Trade Organization (WTO), trade concerns

and disputes under SPS agreement, S4.163

Worobo, R. W., S4.60

Worrall, J. J., S4.137

Worthington, R. J., S4.70

Wosula, E., S2.11

Wosula, E. N., S4.138

Woudenberg, J., S4.138

Wozniak, C. A., S4.154

Wraight, S. P., 283

Wright, A., S4.99

Wright, A. C., S4.126

Wright, D., S4.138

Wright, D. L., 794, S2.11, S4.113, S4.114

Wright, D. W., S4.138

WRKY transcription factors

Aspergillus flavus on maize and, S2.4

of corn, Aspergillus flavus infection and resis-

tance to aflatoxin contamination, S4.40

Wsm gene loci, $\mathrm{S} 4.114$

WSMV. See Wheat streak mosaic virus

Wu, B., S4.123

Wu, T., 597

Wulff, N. A., S4.138

Wyenandt, C. A., S1.3

Wylie, A., S6.11

Wyse, D., S5.1

Xa33 gene, rice resistance against Xanthomonas oryzae pv. oryzae and, 222

Xanthomonas spp.

$X$. albilineans, on sugarcane, OmpA and disease symptom development and colonization, S4.39

$X$. axonopodis

pv. vasculorum, on sugarcane, in Mexico, S4.110

pv. vesicatoria, on tomato, Asophyllum nodosum extracts for control of, S3.2

$X$. campestris

on Arabidopsis, MAMP and, S4.116

on common bean, image analysis and studies of quantitative disease resistance, 434

pv. campestris, on crucifers, evaluating control in greenhouse transplant production, S4.66

pv. translucens, on wheat: effect of inoculation method, inoculum concentration, and plant growth stage on infection development, S4.61; relationship between greenhouse and field reactions to, S5.5

$X$. citri pv. citri, on kumquat and grapefruit, comparative analysis of oxidative management in, $\mathrm{S} 4.33$

X. citri pv. citri

on Buddha hand, S4.66

on citrus: $h m s F$ as virulence factor of, S4.130; $n l x A$ gene and production of lipopoly- saccharide and extracellular polysaccharide, motility, biofilm formation, and stress resistance, S4.140; predisposition of foliage to infection with, S4.13; TAL effector

PthA4-mediated virulence and host gene induction, $\mathrm{S} 4.55$

factors controlling differences in strain host specificity and virulence, $\mathrm{S} 4.58$

on grapefruit and orange, comparison between avrGf1 and $a v r G f 2$ which elicit hyper-

sensitive reactions in, $\mathrm{S} 4.45$

haloacid dehalogenase family phosphatase is required for extracellular polysaccharide production and virulence in, S4.69

in huanglongbing infected citrus, S4.121

regulation of glycohydrolase family proteins

from in xylan during pathogenesis, S4.108

virulence mechanism of, S4.147

X. cucurbitae, on pumpkin, in midwest, $\mathrm{S} 4.8$

$X$. euvesicatoria, on tomato, management in organic production systems, $\mathrm{S} 4.31$

$X$. fuscans pv. aurantifolii, on grapefruit and orange, comparison between avrGfl and avrGf2 which elicit hypersensitive reactions in, $\mathrm{S} 4.45$

$X$. oryzae, on rice

pv. oryzae, Xa33 gene and resistance, 222 pv. oryzicola: $h s h B$ gene, quorum sensing, $c l p$ and, 252; regulation of $e p v$ by DSF-mediated quorum sensing and, 841; variable number of tandem repeats typing scheme for, 948

TAL effectors and virulence, $\mathrm{S} 4.127$

on pepper, cymoxanil and famoxadone for management of, S2.3

$X$. perforans, on tomato

light-activated antibacterial nanoscale formulations for control of, S4.89

Salmonella enterica growth in the phyllosphere following synergistic interaction with, S4.94

on poinsettia, multilocus sequence analysis of, S4.101

on tomato

cymoxanil and famoxadone for management of, S2.3

kasugamycin and kasugamycin-fungicide mixtures for management of, S4.129

in Midwest U.S., S5.7

$X$. translucens pv. undulosa, pathogenic and genetic diversity in North Dakota, 390

Xavier, K. V., S4.138

Xia, H. Q., 267

Xiang, H., S4.69

Xiang, Y., S4.139

Xiao, C., S4.18, S4.109

Xiao, C. L., 315

Xiao, Y., 779

Xie, C., 692, S4.139

Xie, W., 434

Xing, J., S4.59

Xiong, Z., S4.37, S4.139

Xiphinema index (dagger nematode), Grapevine

fanleaf virus in grape and, control by fallow plants under greenhouse and field conditions, 627

Xu, J., S2.7, S4.48, S4.139

Xu, X., 177, 707, S5.10

Xyleborinus spp. (ambrosia beetles), and associated

fungal symbionts in Louisiana, S4.87

Xylella fastidiosa

on blueberry

host ranges of strains, $\mathrm{S} 4.55$

xylem hydraulic conductance and field resistance, $\mathrm{S} 4.54$

characterization of novel secreted proteins from, S4.102

constitutive plasmid-based protein expression in, S6.13

detection of small RNAs in, S4.22 
effects on model host Nicotiana tabacum, S4.88 on grape

alteration of phenolic compounds in xylem sap and tissues during infection with, 816 cell surface LPS and biofilm formation and virulence of, S4.147

control of disease with benign strain of, $\mathrm{S} 4.55$ phoP/Q two-component regulatory system and, S6.11

shifts in secondary metabolic profiles during infection, S4.129

host-switching in, S4.164

impact of zinc on growth and biofilm production of, S4.85

minerals and interactions with host plants, S4.157

modulation of virulence traits by calcium, S4.36

multilocus sequence typing and, 456

on oak, in mid-Atlantic, S4.11

on oleander, real-time PCR for detection and quantification of, S4.48

plant water stress and vector feeding behavior, S4.8

plasmid-encoded PemK toxin of as endoribonuclease, 32

role of calcium in regulation of twitching motility, S4.27

RpfF-dependent regulon of, 1045

on street trees in Washington, D.C., S3.2

subsp. multiplex

on oak, in mid-Atlantic, S4.11

on street trees in Washington, D.C., S3.2

toxin-antitoxin system encoded by, $\mathrm{S} 4.67$

Yaghmour, M. A., S4.139

Yajima, W., S4.23

Yakabe, L. E., S4.76

Yamada, T., 244, 469

Yan, F., S4.21

Yan, G. P., 14

Yan, H., S4.72

Yan, Q., S1.8, S4.130, S4.140

Yang, B., S4.151

Yang, C., S4.63, S4.147

Yang, C.-A., 1054

Yang, H., S4.140

Yang, X., S4.6, S4.86, S4.140

Yang, X. B., S4.142

Yang, Y., S4.131

Yao, N., S4.142

Yaqoob, N., S4.40

Yarmolinsky, D. G., S4.81

Yasuhara-Bell, J. H., S4.141

Yin, C., S4.141

Yin, F., 252

Yin, L., 1094

Yin, Y. N., 315

Ying, F. M., S4.37

Ying, X., S4.141

Yokomi, R., S4.141

Yokomi, R. K., 114, 1168, S4.131

Yokota, S., S4.141

Yoshinaga, A., S4.141

Yoshizawa, N., S4.141

Young, C., S4.21, S4.117, S4.160

Young, H., S4.63, S4.84

Young, H. M., 794, S2.11, S4.114

Young, S., S4.11

Youssef Banora, M., 990

Yu, J., S4.69, S4.130, S4.141

Yu, K., 434

Yu, N., S4.37, S4.139
Yu, S., S4.58, S4.59, S4.142

Yu, Y., 1094

Yuen, J., 429, 1006

Yuen, J. E., 323

Yuen, J. M. F., 185

Yun, H., S4.142

Zaccaron, M. L., S4.142

Zala, M., S4.97

Zamany, A., S6.10

Zambell, C. B., S1.8

Zambolim, L., S4.32

Zambrano Mendoza, J. L., S5.10

Zambrano-Zepeda, E. N., S4.110

Zamudio, K., S4.162

Zandstra, J., S4.17

Zavaglia, A., S4.124

Zea mays (corn; maize)

aflatoxin in

Afla-Guard for management of, S4.133

Aspergillus flavus AF36 for control of in Mexico, S4.89

Aspergillus flavus on

atoxigenic, sporulation and field movement of, S6.2

diversity in fields treated with Aflaguard, S2.9

mating type and biological control of, S4.28

transcriptomic and protein profiling of seed

with varying aflatoxin accumulation, S4.73

WRKY transcription factors and resistance, S2.4

automatic fungicide application to, yield and net

return on investment, $\mathrm{S} 4.3$

Cercospora zeae-maydis on

effects of hybrid and foliar fungicide on disease severity and yield, S5.7

host sensing, stomatal tropism, initiation of stomatal penetration and, S2.6

changes in importance of diseases in past 20

years in corn belt, $\mathrm{S} 4.142$

Clavibacter michiganensis subsp. nebraskensis

on

alternate hosts for, S5.6

distribution and virulence in Minnesota, S4.75

effects on grain quality and seed infection,

S4.101

factors affecting development and severity of, S5.6

infection through natural openings, S4.75

Colletotrichum graminicola on

secondary metabolite genes and gene clusters of, S4.138

transcriptome analysis of, S4.120

Exserohilum turcicum on

effects of hybrid and foliar fungicide on disease severity and yield, S5.7

field evaluation of foliar fungicides for control of, S4.133

extraction of endoparasitic nematodes from,

comparison of methods and root types, S5.2

extraction of nematode species from roots, S4.9

Fusarium verticillioides on, genetic diversity of, S6.4

impact of cropping sequence on diseases, nematodes, and yield of in southwest Alabama,

S4.49

induced systemic resistance in, $\mathrm{S} 4.92$

Maize chlorotic mottle virus in, development of infectious clones for, S4.18

Maize rayado fino virus in, novel sources of resistance to, S5.10

Pantoea ananatis on, in Mexico, S6.6
Pantoea stewartii subsp. stewartii on, regulation of oxidative stress response in, S4.17

predicted interactome for, $\mathrm{S} 4.84$

Rice black-streaked dwarf virus in, S4.80, S5.7

Si-RNAs in, hotspots in viral accumulation, S4.165

Sporisorium reiliana on, $q H S 2.09$ locus and, 692

Stenocarpella maydis on

mapping genes associated with resistance, S4.102

timing and efficacy of fungicide application, S5.8

use of fungicides in, S4.152

WRKY transcription factors of, Aspergillus flavus infection and resistance to aflatoxin contamination, S4.40

Zechmann, B., 662

Zelenev, V., S4.99

Zellermann, E.-M., 23

Zeng, Q., S4.11, S4.63, S4.142, S4.147

Zeng, Y., S2.11

Zhai, C., S4.142

Zhang, A., S4.80

Zhang, C., S4.21

Zhang, D., 692

Zhang, G., S4.30

Zhang, G. R., S4.143

Zhang, J., S4.55

Zhang, L., 692

Zhang, M., 567, S4.31, S4.143

Zhang, N., S1.6

Zhang, R., S4.69

Zhang, S., 692, S4.30, S4.31, S4.39, S4.47, S4.79,

S4.80, S4.81, S4.138, S4.143

Zhang, Y., 841, 1094, S4.76, S4.142

Zhang, Z., S4.59

Zhao, S., 948

Zhao, T., S4.48

Zhao, X., S4.48

Zhao, Y., 252, 841, S3.2, S4.5, S4.8, S4.29, S4.70,

S4.131, S4.143

Zhemchuzhina, N., S4.57

Zheng, D., S4.59

Zhong, S., 539, S4.3, S4.68, S4.95, S4.143, S5.9

Zhou, B., S4.165

Zhou, J., S2.11, S4.144

Zhou, L., S4.50, S4.144

Zhou, S., S4.11

Zhou, X., S4.144, S6.2

Zhou, Y., 252, 841

Zhu, H., S4.144

Zinc, Xylella fastidiosa biofilm production and, S4.85

Zitnick-Anderson, K., S4.145

Zitter, T. A., S4.152

ZLCV. See Zucchini lethal chlorosis virus

Zlesak, D., S4.82

Zoffoli, J. P., S4.100

Zondag, R. H., S4.144

Zoysia spp. (zoysiagrass), Rhizoctonia solani on in Kansas, S4.86 toothpick baiting method for detection and monitoring of, S6.4

Zucchini. See Cucurbita pepo

Zucchini lethal chlorosis virus (ZLCV), in zucchini, insecticide application and secondary dissemination, S4.26

Zucchini yellow mosaic virus (ZYMV), seed transmissibility of, S1.7

Zuluaga, P. A., S4.28

Zurn, J., S4.145

Zwahlen, C., S4.92

ZYMV. See Zucchini yellow mosaic virus Aspergillus flavus on, tissue-specific components of resistance to, 787 